Columbia Law School

Scholarship Archive

1975

\title{
The Future of Sentencing Reform: Emerging Legal Issues in the Individualization of Justice
}

John C. Coffee Jr.

Columbia Law School, jcoffee@law.columbia.edu

Follow this and additional works at: https://scholarship.law.columbia.edu/faculty_scholarship

Part of the Criminal Law Commons, Criminal Procedure Commons, and the Law Enforcement and Corrections Commons

\section{Recommended Citation}

John C. Coffee Jr., The Future of Sentencing Reform: Emerging Legal Issues in the Individualization of Justice, 73 MicH. L. REV. 1361 (1975).

Available at: https://scholarship.law.columbia.edu/faculty_scholarship/542

This Article is brought to you for free and open access by the Faculty Publications at Scholarship Archive. It has been accepted for inclusion in Faculty Scholarship by an authorized administrator of Scholarship Archive. For more information, please contact scholarshiparchive@law.columbia.edu. 


\title{
THE FUTURE OF SENTENCING REFORM: EMERGING LEGAL ISSUES IN THE INDIVIDUALIZATION OF JUSTICE
}

\author{
John C. Coffee, Jr.
}

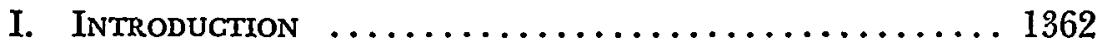

II. The Acquisition of Dispositional Information . . . . 1374

A. The Nature of Dispositional Data ........... 1376

1. Law Enforcement Records ............... 1376

a. Conviction records ................ 1376

b. Arrest records .................. 1377

c. Investigative and intelligence reports ...... 1384

d. Juvenile records .................. 1385

2. Educational Records .................. 1388

3. Clinical Data ..................... 1391

B. The Acquisition Stage: An Overview .......... 1394

1. Problems of Data Quality .............. 1395

2. Problems of Data Transmission ........... 1396

3. The Problem of Parity .............. 1398

III. The Assessment of Sentencing Information . . . . . 1399

A. The Case Attribute Method .............. 1999

B. The Categoric Risk Approach ............. 1405

C. The Clinical Prediction Procedure .......... 1415

IV. Developments in the Case Law ........... 1420

A. Procedural Reform ..................... 1423

1. The Trend Toward Disclosure ........... 1423

2. The Right To Require Verification ......... 1425

3. The Right To Exclude Unreliable Information 1429

4. Appellate Review of the Decision-Making Process 1435

B. The Future of Procedural Reform ........... 1440

C. Substantive Reform: The Roads Not Yet Taken .. 1442

1. The Concept of Proportionality ........... 1442

2. The Problem of De Facto Discrimination ..... 1445

D. A Summary and Evaluation .............. 1452

V. Restructuring the Sentencing Process .......... 1452

A. Increasing the Conduits of Information: The Case for a Parallel Pre-Sentence Study by Defense Counsel .......................... 1454

B. Circumscribing Data Collection: The Case for Less

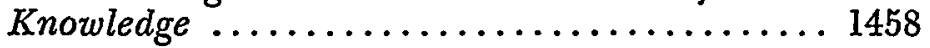




\title{
THE FUTURE OF SENTENCING REFORM: EMERGING LEGAL ISSUES IN THE INDIVIDUALIZATION OF JUSTICE
}

\author{
John C. Coffee, Jr.* \\ "Here I am an old man in a long nightgown making muffed \\ noises at people who may be no worse than I am."1 \\ Judge Learned Hand on Sentencing
}

\section{INTRODUCTION}

$\mathrm{T}$ HE dilemma of the American sentencing judge is qualitatively unique. Because our system of criminal justice has embraced to a degree unequaled elsewhere the rehabilitative ideal that punishment should fit not the crime, but the particular criminal, ${ }^{2}$ the sentencing judge must labor to fulfill the dual and sometimes conflicting roles of judge and clinician. Entrusted with enormous discretion, he is expected to "individualize" the sentence he imposes to suit the character, social history, and potential for recidivism of the offender before him. ${ }^{3}$ Yet, because of the general absence in our

* Member, New York Bar. B.A. 1966, Amherst College; LL.B. 1969, Yale Law School.-Ed.

1. Quoted in M. Franked, CrIminal Sentences 16 (1972).

2. For decisions in which American courts have insisted that the sentencing judge "individualize" sentences in kecping with the character of the offender, see Unitcd States v. Schwarz, 500 F.2d 1350 (2d Cir. 1974); United States v. Daniels, 446 F.2d 967 (6th Cir. 1971); Commonwealth v. Green, $396 \mathrm{~Pa} .137,150,151$ A.2d 241, 247 (1959); Commonwealth v. Cater, $396 \mathrm{~Pa}$. 172, 152 A.2d 259 (1959). In contrast, European countries, most notably Great Britain, have remained predominantly influenced by the Benthamite concept of finding the appropriate quantum of punishment sufficient to deter future commission of the particular crime in question. As a result, the character of the offense appears to have remained the central determinant in their sentencing decisions. See J. ConRad, Crime and ITs Correction 52.53 (1965); N. WALker, SenTENCING IN A RATIONAL SOCIETY 26-32, 118-19, et passim (1969); Regina v. Maguire, 40 Crim. App. 92, 94 (Crim. App. 1956) ("The business of a court is to consider what is the proper length of imprisonment to impose for a particular offense'). Cf. A. Cross, THE ENGLish SENTENCING SYSTEM (1971).

For excellent general studies of the emergence and growth of the "rehabilitative ideal" in American correctional thinking, see American Friends Service Comm., StrugGLE FOR JUSTICE (1971) (in particular, see chapter three) [hereinafter STRUccle FOR JUSTICE]; U.S. TASK Force on Corrections, The President's CoMmn. ON LAW ENFoncement AND ADMINISTRATION OF JUSTICE, TASK FORCE REPORT: CORRECTIONS 2-5 (1967) [hereinafter TASK FORCE REPORT: CORREGrions]; Cohen, Sentencing, Probation, and the Rehabilitative Ideal: The View from Mempa v. Rhay, 47 TEXAS L. REv. 1 (1968).

3. In reality, the sentence imposed in any individual case will be the product of a variety of considerations, only one of which is the desire to rehabilitate or "treat" the offender. A partial list of these other factors would include: (1) the need to protect society, (2) the need to deter both the individual defendant and other potential defendants generally, (3) the need (or desire) to "denounce" the violation of important 
system of meaningful procedures for the appellate review of sentences, ${ }^{4}$ he is denied standards by which to determine any particular sentence or by which to learn what decisions his fellow judges have reached in similar situations.

To facilitate the goal of individualized sentencing, two related practices have developed within our criminal justice system. First, the use of indeterminate sentences ${ }^{5}$ has grown up as a means of providing the sentencing judge and correctional authorities with the flexibility thought necessary to tailor individualized sentences. Second, in order to provide the diagnostic information considered essential for meaningful individualization, an elaborate system for the pre-sentence investigation of the offender has gradually developed, resulting in a far-reaching data-gathering process that requires both considerable time and a sizable bureaucratic infrastructure. ${ }^{6}$

social norms, (4) the need to reward the defendant who pleads guilty for his cooperation with the prosecution, (5) the inclination to punish the defendant if the judge is particularly revulsed by his actions or character, and $(6)$ the need to maintain some degree of equality between the sentences imposed upon higher and lower income criminals. See H. Packer, The Limits of the Criminal Sanction 35-51 (1968). See also M. FRANREL, supra note 1 , at 106. For an attempt to balance these factors in the context of an actual sentencing decision and in the aftermath of the pardon of former President Nixon, see United States v. Braun, 382 F. Supp. 214 (S.D.N.Y. 1974).

Notwithstanding the multitude of factors that may influence any individual sentencing determination, this article will focus on the concept of individualization as a means of achieving rehabilitation both because this theme has subsumed all other considerations in the standard literature of corrections and because it has served as the chief bulwark of those opposed to sentencing reform.

4. Criticizing the unreviewable discretion accorded the American sentencing judge, an American Bar Association study has concluded succinctly: "[ח]n no other area of our law does one man exercise such unrestricted power. No other country in the free world permits this condition to exist." ABA AdvisORY COMMITTEE ON SENTENGING AND Review, ABA Project on Minimum Standards for Criminat Justice, Standards Relating to Appellate Review of Sentences 2 (Approved Draft 1968) [hereinafter ABA Aprellate Review Standards]. See also U.S. TASK Force on the ADMinistration of Justice, President's Conmm. on LAW ENForcenent and Administration of JUstice, TASK FORCE REPORT: THE COURTS (1967) [hereinafter TASK FORCE REPORT: THE CoURTS]. In fairness, however, it must be observed that appellate review is considerably easier to achieve in legal systems, such as Great Britain's, that are chiefly concerned with deterrence rather than "rehabilitation," since in such a context an appellate court is faced with the more manageable task of considering the relationship of the sentence to the character of the offense, rather than its relationship to the character of the offender.

5. Use of the term "indeterminate sentence" involves a definitional problem, since virtually all sentences are indeterminate to some degree between either judicially or legislatively established minima and maxima. For a description of the variety of "indeterminate" sentences, see Advisory Comm. on Sentencing AND REview, ABA Project on Minimum Standards for Criminal Justice, Sentencing Alternatives and ProCEDURES 143 (Approved Draft 1968) [hereinafter ABA SENTENcing Alternatives]. An extreme example is California's indeterminate sentence: The sentencing judge commits for a legislatively fixed maximum term; the parole authority is free to release conditionally at any time thereafter. CAL. PENAL CODE §§ 1168, 3041 (West Supp. 1966).

6. The most detailed descriptions of the mechanics of the pre-sentence inquiry are to be found in the standard probation manuals and guidebooks prepared for 
This article will focus on the mechanics of the individualization process: the manner in which dispositional information is collected, the quality of the resulting data, and the methodologies employed for its communication to and assessment by correctional decision makers. This focus is important because another distinctive feature of the American criminal justice system is the severity of the sentences it imposes. ${ }^{7}$ Not only is the average length of sentences imposed on American offenders far in excess of that imposed in other Western nations, but there is considerable evidence that the average length of sentences has increased in direct response to the transition from a system of standardized sentences to the "humanitarian" system of individualized sentences. ${ }^{8}$ At the same time, those opposing

probation officers. These include: Division of Probation, Administrative Office op THE U.S. Courts, The PResentence Investigation Report (1965) (the standard manual of federal probation offices) [hereinafter PRESENTENGE REPORT]; NATIONAr Council on Crime and Delinguency, Guides for Sentencing (1957) [hereinafter Guides for Sentencing]; P. Keve, The Probation Officer Investigates (1960). See also Advisory Comm. on Sentencing and Review, ABA Project on Standards for Criminat Justice, Stan. dards Relating to Probation 32-40 (Approved Draft 1970) [hereinafter ABA Probation STANDARDS]; Sharp, Presentence Reports, 30 F.R.D. 483 (1961).

More detached, empirical descriptions of the operation of the pre-sentence inquiry can be found in R. Dawson, Sentrencing 11-65 (1969); D. Dressler, Practice and Theory of Probation and Parole (1969); C. Newman, Sourcebook on Probation, Parole and Pardons 114-19 (3d ed. 1968); D. Newman, Conviction 14-18, 222-23 (1966); L. OrLand, Justice, Punishment, Treatment 20-32 (1973); S. Rubin, H. Weihofen, G. Edwards \& S. Rosenzweig, The Law of Criminal Correction 73-108 (2d ed. 1973). See also Katkin, Presentence Reports: An Analysis of Uses, Limitations and Civil Liberties Issues, 55 MINN. L. REv. I5 (1970). In addition, excellent descriptions of particular aspects of the sentencing process are to be found in the various Institutes on Sentencing sponsored from time to time by the various circuit courts of appeals and reprinted in the Federal Rules Decisions.

Finally, overshadowing all other recent empirical studies of sentencing decisionmaking, are two major recent works: sociologist John Hogarth's SENTENCING As A Human Process (1971), the first truly quantitative and systematic study of the sentencing process, the findings of which are discussed in the text at notes 169.75 infra, and psychiatrist Willard Gaylin's PARTIAL JusTICE (1974), which focuses principally on the disparate attitudes, perceptions, and psychologies among sentencing judges.

7. More than one half of the prisoners confined in state institutions in $1960 \mathrm{had}$ been sentenced to terms of 10 years or more. TASK FORGE REPORT: THE COURTs, supra note 4 , at 17. In the federal system, the average sentence of the prison population in 1965 was in excess of 5 years; over 5 per cent of federal prisoners were then serving terms in excess of 20 years. Sentences in excess of 5 years are considered rare in most European countries. See ABA SENTENCing ALTERnatives, supra note 5, at 57. Indeed, it was estimated in 1970 that in one year more than 15,000 offenders in the United States were sentenced to terms of 5 years or more, while only 150 such sentences were given in England. Wall St. J., Sept. 9, 1970, at 1, col. 1, at 17, col. 2, quoted in W. GAYLIN, supra note 6, at 23. Both the ABA Minimum Standards and the Model Sentencing Act recommend that the maximum authorized prison term be set at 5 years. ABA SENTENCING ALTERNATIVEs, supra note 5, at 48, 60-61, 86.

8. Dr. Gaylin reports that the average sentence length for persons committed to federal prison "has risen steadily in the last fifteen years, until now it is almost double the twenty-eight months it was in 1957." W. GaYLIN, supra note 6, at 23. The trend toward longer sentences is, however, less recent than Dr. Gaylin suggests. One of the 
procedural reform and formalization of the sentencing process have chiefly argued that individualization requires that the sentencing judge be given unfettered discretion. ${ }^{9}$ It thus becomes essential to ask what justification exists for the immense faith that has been placed in the ability of correctional decision makers to individualize justice in a rational and equitable manner.

The "individualized treatment model" of the sentencing process has been accepted almost without question for the last generation. The universality of its acceptance seems attributable to the convergence of several different forces: the fundamental, democratic belief that the uniqueness of each individual must be respected, the

first modern indeterminate-sentences systems was adopted in Illinois in 1889; in the first full-scale study of the Illinois system, it was found that, on the average, prisoners sentenced under the indeterminate term statute served longer terms than those serving fixed sentences. Bruce, Burgess, Harno \& Landesco, A Study of the Indeterminate Sentence and Parole in the State of Illinois, $19 \mathrm{~J}$. Am. Inst. Crim. L. \& Criminology, no. 1, pt. II, at 67 (May 1928). Today, California is generally recognized as having adopted the most extreme form of indeterminate sentencing; its most frequently occurring statutory sentence is 1-to-15 years, and such a term is specified for even relatively minor offenses. Correspondingly, the median time served by California inmates ( 36 months) appears to be the longest in the country, and this median figure has actually increased during recent years. STRUGGLE FOR JUSTICE, supra note 2, at 91-93. A recent decision, In re Rodriguez, 14 Cal. 3d 639, 122 Cal. Rptr. 552, 537 P.2d 384 (1975), requires the California Adult Authority to fix a maximum "primary" term at the beginning of a prisoner's sentence, and thus reduces the degree of indeterminacy in the California system. See note 317 infra.

Two other institutions in which the use of indeterminate sentences seems to have been accompanied by longer average sentences are the juvenile court and the experimental "therapeutic" prison. One study of Maryland's experimental Patuxent Institution for Defective Delinquents found that some 38 per cent of the inmates remained institutionalized for a period in excess of the maximum term to which they could have been sentenced to a standard prison. Stanford, A Model Clockwork-Orange Prison, N.Y. Times, Sept 17, 1972, § 6 (Magazine), at 9, 78. Similarly, observers have reported that minors committed to prison by the juvenile court typically serve longer sentences than if they had been sentenced as adults by a criminal court for the same offense. See S. Rudin, Psychiatry and Criminal Law 157 (1965); Chase, Schemes and Visions: $A$ Suggested Revision of Juvenile Sentencing, 51 TExas L. REv, 673 (1973). Symptom. atically, one study has found that juvenile-court judges who identified with the "humanistic, social welfare ideology" of the juvenile court tended to send more juveniles to institutions and for longer periods than did judges whose orientation was more legalistic. See Controluing Delinguents 6, 31-60 (S. Wheeler ed. 1968).

Although it remains arguable that the relationship that clearly exists between indeterminate sentences and lengthier average prison terms is more coincidental than causal, some authorities have speculated that, in the process of adopting an indeterminate sentence system, many state legislatures have in fact simply added to previously specified prison terms a period of indeterminate confinement, thus ensuring that indeterminate sentences would be more punitive. See Dershowitz, Indeterminate Confinement: Letting the Therapy Fit the Harm, 123 U. PA. L. REv. 297, 303-04 \& n.17 (1974).

9. See, e.g., Dorszynski v. United States, 418 U.S. 424 , 441-42 (1974). In a separate opinion, Justice Marshall criticized the majority for rendering the procedural sentencing provisions of the statute there at issue a "nullity" by "holding that the Act was intended to preserve 'the unfettered sentencing discretion of federal district judges." " 418 U.S. at 452. For fuller discussion of Dorszynski, see text at notes 299-304 infra. 
clinical theory that criminal misconduct is the product of psychological abnormality or malfunction, ${ }^{10}$ the desire of behavioral and correctional experts to be free from the interference of lawyers and the confines of an adversarial system, and the unanimously recognized need for some mechanism by which to mitigate the harshness of fixed sentences.

Only recently have critics begun to challenge the liberal rhetoric of rehabilitation. In essence, they have asserted that the "treatment" label has been invoked to conceal punitive actions that in fact have been harsher and more repressive than those tolerated under the earlier system of standardized sentences.11 Support for their charges can be found in a number of carefully conducted studies revealing frequent examples of unjustified disparity in the sentences assigned offenders having similar case histories. ${ }^{12}$ Yet, although a principal

10. One work, representative of the clinical theory, expresses the view that unlawful acts are "signals of distress, signals of failure . . . the spasms and struggles of a submarginal human being." K. MENNINGER, THE CRIME of PUNISHMENT 19 (1968), For critiques of the medical model and the assumption that crime is the product of psychological defect, see STRUGGLE For JUstice, supra note 2, at 40-45; Frankel, Lawlessness in Sentencing, 41 U. CIN. L. REv. I, 31-34 (1971). A report published by the State of New York summarizing its correctional policy contains a sympathetic statement of the "theory of rehabilitation" and expresses the view that antisocial conduct stems from "personal characteristics that impede an individual's ability to function at a generally acceptable level." The Governor's Special Comm. on Criminal Offenders, PredimINARY REPORT 300 (1968) [hereinafter REPORT ON CRIMINAL. OfFenders]. The report concedes, however, that the thesis that crime is the product of psychological disorders has come under increasing academic attack, most notably from Professors Cloward and Ohlin, whose "theory of differential opportunity" holds that "persons who perceive societal obstacles to legitimate fulfillment of goals . . a adopt illegitimate means of attaining those goals." Id. at 289. Thus, in this latter view, illegal acts may reveal not a sick person, but a resourceful one who had adapted to the only opportunities permitted him by society. See Cloward \& Ohlin, Illegitimate Means, Differential opportunity and Delinquent Subcultures, in JuveNILE DELINQUENCY 161 (R. Giallombardo ed. 1966) [hereinafter JuvenILE DeLINQUENCY]. For a brief review of the Cloward and Ohlin position and that of other "environmentalist" theories regarding the causes of crime, see Chase, supra note 8 , at $688-90$.

11. On the popular level this critique has been most notably advanced in STRugcLe For JUSTICE, supra note 2; W. GAYIIN, supra note 6; J. MTrFord, KIND AND UsUAL Punishment (1973); N. Morris \& G. Hawkins, The Honest Politician's Guide to Crume CONTROL (1970). The earliest critiques of the deficiencies of the rehabilitative model can be found in F. Alien, The BorderLand of Criminal Justice (1964); Cohen, stupra note 2; Kadish, Legal Norm and Discretion in the Police and Sentencing Processes, 75 HARv. L. REv. 904 (1962). One of the first critics to express skepticism about the feasibility of achieving meaningful individualization through the conventional means of an in-depth study of the individual offender was Professor Sheldon Glueck of the Harvard Law School. See Glueck, The Sentencing Problems, Fed. Probation, Dec. 1956, at 15, 19. As a result, Professors Sheldon and Eleanor Glueck were also among the first to turn to standardized classification systems-with highly debatable results. See notes 207, 211 infra.

12. A 1974 study by the Federal Judicial Center, in which the 50 judges of the district courts of the Second Circuit participated, has provided the most dramatic evidence so far of the disparities that exist between the sentencing practices of individual judges. Presented with identical actual pre-sentence reports, the judges assigned 
target of these critics has been the institution of the indeterminate sentence, only a few of them seem prepared to urge the return to a system of standardized sentences. Thus, because some degree of indeterminacy seems likely to remain a characteristic of most sentencing structures, ${ }^{13}$ the critical question becomes: upon what criteria are offenders who have committed similar crimes to be differentiated?

For some time, the "individualized treatment model" has approached this question of classification by postulating three basic assumptions:

(1) that the task of classifying offenders is essentially a clinical process in which the lawyer's role is superseded by that of the impartial behavioral expert;

(2) that the likelihood of accurate diagnosis, intelligent individualization, and, ultimately, rehabilitation increases in proportion to the volume of information that can be collected about the offender; ${ }^{14}$ and

(3) that the criminal act committed by the offender is a fact of only limited diagnostic significance as compared with information revealing the basic personality disorders that led to the commission of the crime. ${ }^{15}$

widely varying sentences on the same facts; the sentences for the same offender ranged in some cases from as much as 20 years plus a heavy fine to 3 years and no fine. A Partridge \& W. Eldridge, The Second Circuir Sentencing Study 6-7 (1974). The report concluded that "considerable disparity exists in a substantial proportion of Second Circuit cases." Id. at 21. Other studies include Seymour, 1972 Sentencing Study for the Southern District of New York, 45 N.Y. ST. B.J. 163 (1973); Zumwalt, The Anarchy of Sentencing in the Federal Courts, 57 JUDICATURE 96 (1973). See also M. FRANKEL, supra note 1.

13. For example, both the Model Sentencing Act (published by the National Council on Crime and Delinquency in 1963) and the Model Penal Code (prepared under the auspices of the American Law Institute in 1961) employ the indeterminate sentence, but confine it within far narrower limits than the one-to-fifteen year sentence customarily assigned in California.

14. A number of sentencing cases have defended this premise by broadly and unqualifiedly asserting that the "sentencing judge's access to information should be almost completely unfettered in order that he may 'acquire a thorough acquaintance with the character and history of the man before [him]." United States v. Schipani, 435 F.2d 26, 27 (2d Cir. 1970), cert. denied, 401 U.S. 983 (1971). See Williams v. New York, 337 U.S. 241, 247-52 (1949), discussed in the text at notes 224-29 infra. In marked contrast, English courts seem to receive pre-sentence reports of relatively modest scope. See Meador, The Review of Criminal Sentences in England in ABA ApPELLATE REVIEW StANDARDS, supra note 4, app. C, at 94, 108-09.

15. See Hakeem, $A$ Critique of the Psychiatric Approach to Prevention of Juvenile Delinquency, in JUVENILE DeLINQueNCY, supra note 10, at 453, 457. Many forensic psychiatrists and criminologists consider the early childhood experiences of the offender, his home life, relationships with parents, and the date of his first encounter with law enforcement authorities, to be the decisive factors in any prediction of recidivism. See S. Glueck \& E. Glueck, Predicting Delinquencx and Crime 16-17 (1959); Guides for SENTENCING, supra note 6, at 38; Stanford, supra note 8, at 74. Cf. Brancale, Diagnostic Techniques in Aid of Sentencing, 23 LAw \& CONTEMP. Prob. 442 (1958). 
These assumptions, however, have come under increasing attack by students of the correctional process. Among the principal elements in their critique of the "individualized treatment model" are the following:

(1) clinical techniques for the evaluation of the offender tend to err substantially on the side of overprediction; ${ }^{16}$

(2) more information does not always assist diagnosis, but may confuse it and lead to unintended discrimination based on the subject's exposure to record-keeping; ${ }^{17}$

(3) the process of distinguishing among individuals on the basis of their innate character, rather than their explicit actions, is too speculative and subjective to have a substantial impact where basic questions of human liberty are involved;18 and

(4) the aims of deterrence and rehabilitation are sufficiently incompatible that the tasks of diagnosing and treating the offender should be severed from the criminal justice system and assigned to persons who do not have responsibility for determining the length of sentence. ${ }^{19}$

While the commentators do not universally share all of these views, ${ }^{20}$ one basic precept does underlie this new school of criticism: the view that the goal of individualization based upon an understanding of the whole person is largely beyond the realistic capabilities of the criminal justice system and often in direct conflict with the goal of treating similar offenders similarly. Thus, the prescription of these critics is basically conservative: restrict the discretion accorded dispositional decision makers and, by various means, impose

16. See Diamond, The Psychiatric Prediction of Dangerousness, 123 U. PA. L. Rev. 439, 447 (1974) (concluding that psychiatrists tend "to over-predict dangerousness greatly, by a factor somewhere between ten and a hundred times the actual incidence of dangerous behavior"); Dershowitz, Psychiatry in the Legal Process: "A Knife That Cuts Both Ways", 51 Judicarure 370 (1968); Morris, The Future of Imprisonment: Toward a Punitive Philosophy, 72 Mrch. L. Rev. 1161, $1164-73$ (1974); Settle \& Oppegard, The Pre-Trial Examination of Federal Defendants, 35 F.R.D. 475, 479-80 (1964); Steadman, The Psychiatrist as a Conservative Agent of Social Control, 20 Socun Prop. 263 (1972). See also text at notes 211-17 infra.

17. See, e.g., TASK Force REPORT: CORRECTIONs, supra note 2, at 14.

18. Thus, Struggle for Justice, probably the most representative expression of this new critique, recommends that "the law ... deal only with a narrow aspect of the individual, his criminal act or acts." STRUGGLE FOR JUSTICE, supra note 2, at 147. See also Allen, The Borderland of the Criminal Law: Problems of "Socializing" Criminal Justice, 32 SOCIAL SERv. REv. 107, 117 (1958).

19. See STRUGGLe FOR JUSTICE, supra note 2, at 97-98.

20. For example, Judge Frankel, who considers that current procedures for individualization constitute at best a "dubious process," M. FrankEL, supra note 1, ch. 3, nevertheless maintains that some objective basis for differentiating among offenders on their individual merits can be found. $I d$. at 11 . For a similar view and an attempt at making a list of such factors, see N. WALEER, supra note 2, at 118. 
greater standardization on the process by which such decisions are reached.

This new skepticism concerning the correctional system's ability to measure character and predict future behavior accurately enough to determine fundamental questions of liberty has already led to signs of a major division among criminologists. ${ }^{21}$ Yet, whether attributable to an excessive deference to social scientists ${ }^{22}$ or simply to a preoccupation with the trial stage of the criminal justice system, lawyers as a group have avoided serious engagement with the problems of the dispositional stage. This is unfortunate: In a legal system in which an estimated ninety per cent of all convictions are the result of guilty pleas, ${ }^{23}$ sentencing and parole are the issues of paramount importance to most defendants and constitute their chief impressions of the fairness of the criminal justice system.

Before going further, it is necessary to outline briefly the presentence investigation that initiates the dispositional process. The key document both at this stage and at the later parole stage is the pre-sentence report. Its recommendations are generally followed by the sentencing judge ${ }^{24}$ and the extent and scope of its investigation of the defendant overshadow subsequent inquiries at the parole or custodial classification stages. ${ }^{25}$ Indeed, the assessments made and data collected during the pre-sentence investigation pursue the defendant and become the core of the parole board's case summary file on him. As a consequence, misinformation that enters the pre-

21. For a brief dialogue setting forth many of the principal issues in this debate, see Nietzel, Psychiatric Expertise In and Out of Court: $A$ Reply to Blinder, 58 JudiCature 39 (1974), and Blinder, A Response to Nietzel, 58 JudraAture 41 (1974).

22. Dr. Gaylin, himself a psychiatrist, has theorized that the lawyer's lack of familiarity with the social sciences "permits glorification" of the degree of expertise underlying the judgments made by social scientists. In reality, he adds, greater knowledge of the fields of behavior and sociology would cause the lawyer to recognize the "incredible failure of these disciplines ... in solving the problems of antisocial behavior." W. GAYLIN, supra note 6, at 100.

23. ABA Appellate Revew Standards, supra note 4, at 60; D. Newman, supra note 6 , at 3 .

24. Carter \& Wilkins, Some Factors in Sentencing Policy, 58 J. Grum. L.C. \& P.S. 503, 504-05 (1967). Indeed, Dr. Gaylin has concluded in his study of sentencing that "[i]n many courts, the probation officer rather than the judge is the sentencer." W. GAYLIN, supra note 6, at 13 .

25. Offenders are classified at three principal stages: during the pre-sentence investigation, during the diagnostic and orientation process on their initial entry into prison, and during the pre-parole investigation that may precede release. See $\mathbf{R}$. DAwson, supra note 6, at 242-43. See also Sirico, Prisoner Classification and Administrative Decisionmaking, 50 TEXAS L. REv. 1229 (1972). The last two inquiries rarely duplicate the factual investigation conducted by the probation officer writing the presentence report, but instead tend to rely on the pre-sentence report and investigate other areas, such as the clinical aspects of the offender's case or his ability to maintain himself socially and economically if released on parole. 
sentence report is likely to have a multiple impact on the offender's future.

In intent and methodology, the pre-sentence investigation has been described as an effort to determine "the social credit rating of the individual." 26 The analogy is accurate: As with investigations conducted by credit agencies, the scope of the pre-sentence investigation is virtually unlimited. The subject's homelife, childhood, educational and employment history, political and religious attitudes, and sexual experiences (particularly in the case of the female offender) are all considered relevant information. ${ }^{27}$ Chief importance, however, is likely to be given to past encounters with law enforcement authorities, including even inconclusive investigatory contacts. 28

To obtain the necessary data, the probation officer is expected and empowered to contact all social agencies that have ever dealt with the offender and receive full access to their files; these include schools, psychiatric clinics, welfare departments, and juvenile authorities. In addition, he will interview the offender, and possibly his relatives or neighbors. In earlier times, reliance was principally placed on these oral techniques. ${ }^{29}$ But, with growing caseloads and the increasing availability of centralized databanks, the probation officer has become increasingly dependent on recorded information and increasingly able to delve deeper into the recorded aspects of the individual's prior life. ${ }^{30}$

In one major respect, the analogy between the pre-sentence report

26. Wallace, Aids in Sentencing, 40 F.R.D. 433, at 433 (1965).

27. While the degree of standardization varies, probation manuals typically recommend at a minimum that the report contain a separate section dealing with cach of the following categories: prior record, family history, social adjustment, education, marital status, personality traits, attitudes toward probation, and physical and mental health. See R. DAwson, supra note 6, at 35; PREsentence RePort, supra note 6; Guides FOR SENTENCING, supra note 6. The Model Penal Code recommends that the pre-sentence report have a similarly extensive scope. MODEL PENAL CODE \& 7.07(3) (Proposed Official Draft 1962).

28. See note 84 infra.

29. For criticism of this reliance on oral techniques, see Schaffer, The Defendant's Right of Access to Presentence Reports, 3 Crum. L. BuLr. 674 (1967).

30. An extensive overview of the growth and significance of computerized databanks is provided in National Academy of Sciences, Databanks in a FreE Society (A. Westin \& M. Baker eds. 1972) [hereinafter DataBanks]. The study found that although computerization of databanks had not generally resulted in an increase in the amount and scope of information being collected over the already extensive amount of information that manual databanks had acquired, it did greatly enhance the ease and efficiency with which the information could be obtained. For studies on manual databanks and their use in the correctional context, see A. NEIER, Dossrer: THE SECreT FILES THEY KeEP ON YOU (1975); ON RECORD (S. Wheeler ed. 1969) [hereinafter ON RECORD]; Coffee, Privacy Versus Parens Patriae: The Role of Police Records in the Sentencing and Surveillance of Juveniles, 57 CoRNELr L. REv. 571 (1972). 
and a private credit report fails: Victims of misinformation in credit reports have legal remedies. ${ }^{31}$ In contrast, in most jurisdictions the offender lacks any right to inspect his pre-sentence report and, hence, has virtually no opportunity to learn of misinformation..$^{32}$ In the past his principal protection has been the relative inaccessibility of most nonessential data concerning him. But today, as the barriers to total data access progressively fall, this situation has changed.

This transition is important, for its occurrence gives one considerable reason to believe that the basic sentencing reform that civil libertarians have sought for three decades-disclosure of the presentence report to the defendant and his counsel-may have become obsolete. ${ }^{33}$ Three critical, but barely noticed, developments may account for this. First, the growth of computerized and manual databanks has intensified existing problems of sentencing misinformation by increasing the amount of accessible information, and has created new problems because of the tendency of these systems to communicate sensitive data in an incomplete or overly compressed fashion. Second, the amount of psychiatric.and clinical information presented to the sentencing judge and other dispositional decision makers has grown significantly. This development is attributable both to the increased accessibility to the probation officer of the records main-

31. The contrast is striking between the protection against injury through misinformation afforded the economic status of the citizen by the Fair Credit Reporting Act, 15 U.S.C. $\S \S 1681-81$ t (1970), and the virtual absence of protection in the case of the offender, whose vulnerability to misinformation seems far greater. Under the Fair Credit Reporting Act, the aggrieved citizen may demand disclosure of the information in his credit file, contest and correct errors, require the deletion of information over seven years old, record in his file that a dispute over challenged facts was not resolved, and, in some circumstances, obtain damages.

32. See Cohen, supra note 2, at 48-59; Katkin, supra note 6, at 24-25. Courts have consistently held that the due process clause of the fourteenth amendment does not require disclosure of the pre-sentence report. See United States v. Lowe, 482 F.2d 1357 (6th Cir. 1973); United States v. Fischer, 381 F.2d 509 (2d Cir. 1967), cert. denied, 390 U.S. 973 (1968). With the amendment of rule 32(c) of the Federal Rules of Criminal Procedure to require disclosure in most instances, the constitutional issue has become academic, except at the state level. For an excellent discussion of the pros and cons of mandatory disclosure, see ABA SENTENCING ALTERNATIVES, supra note 5, at 210 . 25; C. Wright, Federal Practice and Procedure: Criminal \$ 524 (1969); Lehrich, The Use and Disclosure of Presentence Reports in the United States, 47 F.R.D. 225 (1969). Disclosure is recommended in ABA SEnTEncing AIternatives, supra, § 4.4; Model Penal Code $\S 7.07(5)$ (Proposed Official Draft 1962); Model Sentencing Act $\S 4$ (1963).

33. Ironically, this has taken place just at the moment when widespread adoption of mandatory disclosure appears imminent: With the amendment of rule 32(c) of the Federal Rules of Criminal Procedure to provide for mandatory partial disclosure of the pre-sentence report in most instances at the federal level, see text at notes 242-45 infra, it now appears likely that remaining opposition to disclosure at the state level will eventually collapse. 
tained by educational and other welfare agencies, ${ }^{34}$ and to the emergence of psychiatric court clinics, which provide diagnostic advice directly to the sentencing judge for use in the dispositional process. ${ }^{35}$ In either case, such information, consisting generally of an apparently expert and conclusory assessment of the offender, is markedly different from the basically factual information provided in the traditional pre-sentence report. ${ }^{36}$ Finally, the newest development in correctional decision-making has been the formulation of statistically based prediction tables that seek to measure an offender's risk of recidivism on the basis of the actuarially determined risk that historically has been associated with certain pre-selected variables such as a prior arrest record, an unstable employment history, or, even more ominously, the existence of relatives having criminal histories. ${ }^{37}$

A simple example may reveal the gradations of the problem. Assume that a state has a penal statute prescribing a one-to-twentyyear term for robbery (the intention of the statute being to cover both simple robbery and more aggravated cases of armed robbery). Assume next that a judge, upon reading a pre-sentence report in a robbery case, discovers a reference to the fact that the defendant "had a knife" at the time of the robbery and thus assigns a twentyyear term on the assumption that this was a case of armed robbery. Assume finally that the knife in question was in fact only an innocuous penknife..$^{38}$ For years, critics have employed such an example to demonstrate the need for disclosure of the pre-sentence report and an opportunity to rebut or explain any facts that might be given significant weight in the determination of the sentence.

34. For descriptions of the increasing amount and accessibility of the personal information maintained by such agencies see A. NEIER, supra note 30, at 17-27; Goslin \& Bordier, Record-Keeping in Elementary and Secondary Schools, in ON REcond, supra note 30, at 29. See also InEORMation Technology in a Democrary (A. Westin ed. 1971) [hereinafter INFORMATION TECHNOLOGY].

35. For analyses of the court clinic see Bendt, Balcanoff \& Tragellis, Psychiatric Examination of Alleged Offenders, 58 A.B.A.J. 371 (1972); Campbell, Sentencing: The Use of Psychiatric Information and Presentence Reports, 60 KY. L.J. 285, 291.94 (1972); Fartman, Social Issues and the Court Psychiatric Clinic, Fed. Probation, Sept. 1969, at 37.

36. While the distinction between "factual" information and diagnostic evaluations is important since the latter category clearly requires more sophisticated procedures to ensure fairness to the defendant, this distinction, as Professor Campbell has properly cautioned, see Campbell, supra note 35, at 287 n.14, should not be overdrawn: Other types of information traditionally found in the pre-sentence report, such as teacher and employer evaluations, also contain opinions and characterizations and use terminology requiring interpretation.

37. For brief descriptions of these techniques, see W. REckress, ThE CRIME ProsLEM 750-51 (4th ed. 1967); TASK FORCE REPORT: CORRECTIONS, supra note 2, at 79-82; McGee, Objectivity in Predicting Criminal Behavior, 42 F.R.D. 192 (1966).

38. For a situation in which a small penknife was confused with a weapon to the considerable prejudice of the defendant, see D. Newman, supra note 6 , at 223. See also Kohlman v. Norton, 380 F. Supp. 1073 (D. Conn. 1974). 
But now, alter the foregoing hypothetical and assume that the misinformation that has influenced the sentencing judge is not a statement of fact, but of opinion: for example, a statement that a school psychologist had once years before diagnosed the offender as a "belligerent paranoid." Or, to pose a harder case, suppose the court clinic reports that it has diagnosed the offender as "antisocial," a typology that implies the individual is unlikely to be easily rehabilitated. ${ }^{39}$ In such cases can it reasonably be expected that the effect of such "clinical" judgments will be offset by disclosure? Or, to consider another variant, suppose the pre-sentence report states that the defendant's name appears on a list of "dangerous militants" maintained by the local police department, ${ }^{40}$ or that the state's criminal history databank has received reports that the defendant has been involved in narcotics traffic. ${ }^{41}$ In each of these cases, the pejorative weight of the unsubstantiated statement coupled with its lack of specificity is likely to make effective rebuttal impossible. ${ }^{42}$

The point here is not only that the remedy of disclosure may often prove inadequate, but that the process of assessing offenders has entered a new era as different from the old era of intuitive judgments as electronic data processing was from punched card systems. The issues associated with these new techniques involve more than procedural questions. For instance, the use of psychiatric typologies for the classification of offenders raises fundamental questions about the etiology of crime that have split the profession of psychiatry: Is the offender "sick" simply because he has committed a serious crime? Are there distinct types of criminal illness that require different strategies and lengths of "treatment"? Should the type and length of incarceration the offender is assigned depend upon a diagnosis that other reputable schools of psychiatry would reject? Similarly, the use

39. Although the number of psychiatric typologies in use seems at times to equal the number of practicing forensic psychiatrists, the President's Commission has suggested a standardized classification of offenders as "prosocial," "antisocial," "pseudosocial," or "asocial." See TASK FORCE REPORT: CORRECTIONs, supra note 2, at 20-22. Within this typology, the characterization of "antisocial" represents a judgment that an individual is the most difficult type of offender to rehabilitate.

40. See text at note 95 infra for a discussion of the use of "status codes" by police departments.

41. See United States v. Weston, 448 F.2d 626 (9th Cir. 1971).

42. Note that one similarity between the statistical and clinical predictive techniques is that "diagnosis" leads directly to "outcome"; i.e., while the expert avoids formally recommending a dispositional result, each diagnostic alternative may be matched with a specific dispositional recommendation. For example, labeling the offender as "antisocial" is clearly a recommendation that probation be denied. In consequence, the sentencing judge may be reduced from the role of key decision maker to the almost clerical one of matching diagnoses and dispositions. While it is possible to argue that the clinician, and not the judge, should be the authoritative decision maker, such a re-allocation of authority certainly undercuts the relevance of existing procedural remedies, such as disclosure of the pre-sentence report. 
of prediction tables raises basic jurisprudential issues: Should the sentence be based upon such morally neutral (and potentially discriminatory) factors as level of education, past employment history, or childhood relationships with parents? Or, phrased differently, should any kind of statistical profile be used to determine that an offender is a "high risk" case, so long as the same profile is shared by a great number of citizens who have committed no crimes?

Analytically, a distinction must be drawn between those issues that relate to the kind and quality of the data used in correctional decision-making and those that relate to the underlying assessment techniques utilized once this data has been collected. The road map for this article follows from that distinction. Part II considers issues relating to the kind of information collected and utilized in the making of dispositional decisions. Part III focuses on the three basic methodologies employed to analyze that data: the "case attribute" system of the caseworker, the actuarial techniques of the statistician, and the typological classification systems of the clinician. Part IV examines the legal remedies either developing or foreshadowed by the current case law in order to measure their effectiveness against the problems earlier noted. Finally, in Part V, alternative configurations to the current structure of dispositional decisionmaking will be considered.

\section{The Acquisition of Dispositional Information}

No technique for the systematic assessment of data can long outperform its informational inputs. To the computer scientist, this axiomatic truth is known as the "'GIGO Effect'-Garbage In, Garbage Out." 43 Nevertheless, one of the least studied areas of the correctional process has been the quality of its informational inputs. Those few commentators who have investigated the reliability of the data contained in dispositional reports have, however, identified several common deficiencies: the offender is regularly portrayed in highly stereotyped and superficial terms, ${ }^{44}$ the reports themselves contain a suspiciously high number of pejorative labels and psychiatric expres-

\footnotetext{
43. Databanks, supra note 30, at 300 . Another variant of this axiom is "Garbage In, Gospel Out," which is intended to express the possibility that the end user will assume that data presented in a systematic format (particularly when provided through a computer) has been carefully researched and checked. Whatever the over-all accuracy of this latter axiom (Westin and Baker in general view it skeptically. Id. at 262), it may have special relevance to reports tendered by probation officers and other law enforcement officials, since, as Professor Skolnick has observed, a "presumption of regularity" is given by most recipients of data to reports received from law enforcement authorities. J. SkolNick, JUSTICE WrTHOUT TRIAL 198 (1966).

44. Comment, The Parole System, 120 U. PA. L. REv. 282, 302-04 (1971). Sec also M. FrankeL, supra note 1, at 34; Settle \& Oppegard, supra note 16, at 479-80.
} 
sions ${ }^{45}$ and are permeated by a vast amount of irrelevant information that interferes with both analysis and comparison of the offender. ${ }^{46}$

The range of these criticisms indicates that the problem of data quality involves a continuum of misinformation, ranging from simple factual errors to subtler distortions that result from innuendo or ambiguity. The dimensions of this problem emerge more clearly by contrasting the kinds of errors present in several cases that have attained classic stature in the debate over sentencing reform.

In State v. Killian, ${ }^{47}$ a nineteen-year-old first offender received the unusually severe sentence of seven-to-ten years after pleading guilty to possession of marijuana. Later, it was discovered that this sentence was the result of an undisclosed, false statement in the presentence report that the youth had raped a juvenile girl. Because of ambiguities in police records, the defendant had been confused with another individual who had been identified as the rapist. ${ }^{48}$

In State v. Pohlabel, ${ }^{49}$ a defendant who stole a checkbook and passed seven checks, totaling approximately $\$ 1500$, received seven consecutive terms of three-to-five years each-that is, a total sentence of twenty-one to thirty-five years. After eight years in prison, the defendant learned that the pre-sentence report described him as "a master of deception" who had "spent the greater part of his life in penal institutions"50 and who had been sentenced to life in prison in another state. In fact, the defendant had previously been convicted only once, as a juvenile. ${ }^{51}$

Finally, in United States $v$. Weston, ${ }^{52}$ a federal judge gave a maximum twenty-year sentence to a young female defendant with no prior record of a drug-related offense who had been convicted of possession of a small quantity of heroin. In doing so, the judge explicitly relied on statements made by an anonymous informant who had identified the girl as the chief drug supplier for the region. Eventually an appellate court reversed, stating that the lurid, but

45. Sirico, supra note 25 , at 1231 .

46. TASK FORCE REPORT: CORRECTIONs, supra note 2, at 19. This tendency toward overinclusion of irrelevant data is even more pronounced at the juvenile court level. See S. Fox, Juvenile Courts in a Nutshell 207 (1971).

47. 91 Ariz. 140, 370 P.2d 287 (1962).

48. 91 Ariz. at $144-45,370$ P.2d at $290-91$.

49. 61 N.J. Super. 242, 160 A.2d 647 (App. Div. 1960).

50. 61 N.J. Super. at 247, 160 A.2d at 650.

51. See also United States v. Myers, 374 F.2d 707 (3d Cir. 1967); United States v. Magliano, 336 F.2d 817 (4th Cir. 1964).

52. 448 F.2d 626 (9th Cir. 1971). 
unsubstantiated, story would have been insufficient to support even a search warrant or an arrest. ${ }^{53}$

While the theme of fortuitous discovery of error runs through these cases, there are important differences among them. Killian involved a simple factual error, which disclosure of the pre-sentence report to defense counsel might be expected to correct. Pohlabel, however, involved more: a mixture of factual mistake and stylistic hyperbole in the characterization of the offender that could have remained partially uncorrected even if the pre-sentence report had been disclosd. In contrast to these two cases, Weston involved what may have been a tale of sheer fantasy; disclosure alone was wholly inadequate to rectify this misinformation, since the charges were both broad and nonspecific. Only the unusual decision of the appellate court to require the probation department to corroborate its allegations prevented a miscarriage of justice. Thus, once the presentence report contains not only simple factual errors, but vague characterizations and undocumented charges, new problems are engendered that the traditional remedy of disclosure is probably inadequate to resolve.

Accordingly, it becomes important to examine the varieties of data actually encountered during the pre-sentence inquiry in order to measure the adequacy of the traditional remedy of disclosure against the kinds of distortion that in fact occur. In this section, we will therefore successively consider the following categories of recorded information: law enforcement records, educational and welfare agency records, and clinical and psychiatric records.

\section{A. The Nature of Dispositional Data}

\section{Law Enforcement Records}

Law enforcement records constitute the principal source of recorded information upon which the pre-sentence report relies. ${ }^{54}$ At least four separate categories of law enforcement records can be distinguished on a continuum ranging from generally reliable to highly speculative: conviction records, arrest records, investigative reports, and juvenile records.

a. Conviction records. Although records of the offender's prior convictions clearly constitute the most reliable form of information contained in law enforcement files, probation officers neither acquire nor verify such information in a consistent fashion. For example, in

53. 448 F.2d at 631 .

54. The majority of the information contained in the pre-sentence report comes from two sources: interviews with the defendant and law enforcement records. $R$. DAw. son, supra note 6 , at 14 . 
requiring disclosure of conviction records to a defendant, the Third Circuit recently noted that " $[\mathrm{r}]$ eporting policies are so fragmentary that this court has been unable to find any clear statement of the policy followed by the states." 55 The court further observed that "[n]o standards for accuracy are demanded,"56 and that extra-judicial sources or telephone inquiries might be utilized to obtain lists of prior convictions. ${ }^{57}$ The lack of standards for the reporting of prior convictions led the court to conclude that it was even possible that convictions unrelated to the defendant might be mistakenly attributed to him. ${ }^{58}$

The information provided by the discovery of a prior conviction is often minimal. If the record indicates that the offender has previously been convicted of assault, the question remains whether the underlying incident involved an intra-family dispute, a minor tavern brawl, or a serious case of armed robbery that was plea-bargained down to the lesser charge of assault. To obtain the supplementary information necessary to evaluate the seriousness of prior crimes, the probation officer may rely upon such questionable sources as the prosecutor's file or the memory of local law enforcement authorities. If the prior conviction was in juvenile court, the actual offense may remain concealed under the standard statutory labels of "juvenile delinquency," "wayward child," or "person in need of supervision." 59

b. Arrest records. Despite the criticisms of model codes and commentators alike, ${ }^{60}$ arrest records are universally utilized in sentencing in the United States. ${ }^{01}$ Unlike conviction records, arrest records

\footnotetext{
55. United States v. Janiec, 464 F.2d 126, 130 n.8 (3d Cir. 1972).

56. $464 \mathrm{~F} .2 \mathrm{~d}$ at 128 n.4.

57. 464 F.2d at $127-28$ \& n.4.
}

58. 464 F.2d at 129. For a description of an incident in which such a mistaken attribution of conviction records occurred, see Project, Parole Release Decisionmaking and the Sentencing Process, 84 YALE L.J. 810, 834 n.107 (1975).

59. Because, prior to In re Winship, 397 U.S. 358 (1970), a lesser standard of proof was required in juvenile court, there is also less assurance in the case of a prior juvenile conviction that the offender was truly guilty. In general, experts have expressed "almost universal dissatisfaction with the accuracy of official records on delinquency." Erickson \& Empey, Court Records, Undetected Delinquency and DecisionMaking, 54 J. CRrm. L.C. \& P.S. 456, at 456 (1963).

60. See ABA Probation Standards, supta note 6, § 2.3, at 37; Hess \& LePoole, Abuse of the Record of Arrest Not Leading to Conviction, 13 CRIME \& Delinguency 494 (1967).

61. Virtually all the standard probation manuals agree that an essential element of the pre-sentence report is a section discussing prior arrests and law-enforcement contacts. See, e.g., P. KEVE, supra note 6, at 77. See also R. DAwson, supra note 6, at 27-30. To date, the case law has not placed substantive limitations on the use of arrest records in dispositional decision-making. See Jones v. United States, 307 F.2d 190, 192 (D.C. Cir. 1962) (sanctioning the use at sentencing of an arrest record not leading to a conviction). The first signs of a counter-trend are, however, visible in the recent case of Tarlton v. Saxbe, 507 F.2d 1116 (D.C. Cir. 1974), discussed in notes 272-75 infra and accompanying text. 
indicate no more than an encounter with the law. Yet, these records are relevant to the pre-sentence inquiry only if they are viewed as evidencing the guilt of the defendant. Objections to their use as a factor in dispositional decision-making can be summarized as follows: Arrest data as currently available are generally incomplete or inaccurate; even if the data were updated regularly, their use invites false comparisons and produces discriminatory results; use of arrest data initiates the "labeling" process by which marginally delinquent individuals are turned into confirmed criminals.

Whatever probative value arrest records might possess is initially undercut by the manner in which data concerning arrests are recorded and maintained. Typically, the search for a prior arrest record is pursued through the FBI's national criminal-history databank or a similar state network, such as the New York State Identification and Intelligence System. Yet, as one federal court noted, the FBI lacks the capacity to determine systematically the subsequent disposition afforded the arrest. ${ }^{62}$ Thus, if a defendant is subsequently exonerated of a charge, or the prosecution dismisses for lack of evidence, this information might well go unrecorded.

The sheer volume of the ambiguities created by the failure to expunge records of arrests not followed by a conviction is best illustrated by the FBI's own statistics. For 1973, FBI records indicate over nine million arrests. Of the adults arrested for FBI Crime Index offenses, approximately thirty-eight per cent were not convicted of the alleged crime or a lesser included offense; of the juveniles arrested about half neither had formal charges preferred against them nor were referred to juvenile authorities. ${ }^{63}$ Thus, in 1973 alone, several million arrest-only entries were lodged in police files across the country. Estimates of the number of individuals already having a nontraffic arrest record range as high as fifty million. ${ }^{64}$ One study predicts that 50 per cent of American males will acquire a nontraffic arrest record at

62. Menard v. Saxbe, 498 F.2d 1017, 1026 (D.C. Cir. 1974). The court continued: "There are no controls on the accuracy of information submitted by the contributing agencies." 498 F.2d at 1026. Most criminal record bureaus have not made any attempt to segregate or withhold arrest data known to be incomplete or stale. Databanks, supra note 30 , at 387 .

63. Federal Bureau of Investigation, Uniform Crime Reports 1973, at $34-85$ [hereinafter REPORTs 19xx]. See DATABANRs, supra note 30 , at 387 (estimates 3.5 million annual arrest-only entries). In 1974, the FBI's criminal identification files contained approximately 19 million sets of fingerprints. Menard v. Saxbe, 498 F.2d 1017, 1021 (D.C. Cir. 1974).

64. Gough, The Expungement of Adjudication Records of Juvenile and Adult Offenders, 1966 WASH. U. L.Q. 147. 
- some point in their lives, ${ }^{65}$ and that the probability for a black urban male may be as high as 90 per cent. ${ }^{66}$

There have also been indications that the information recorded in state and federal criminal-history databanks is of dubious reliability. Professors Westin and Baker have reported that at the time the FBI computerized its files, thirty-eight per cent of existing warrants were discovered to be outdated or invalid. ${ }^{67}$ Similar levels of inaccuracy were detected when the New York State Identification and Intelligence System computerized its criminal history records. ${ }^{68}$ Mistakes have also been found to occur because of the tendency for a single incident to acquire multiple listings as separate entries are made at each stage of the criminal prosecution (arrest, indictment, conviction, and sentencing) with the result that one offense is magnified into several. ${ }^{69}$

Given the ubiquity of arrest records (and the strong likelihood that a far greater number of citizens have committed offenses that would support an arrest $\left.{ }^{70}\right)$, the question must be asked: what do arrest records actually measure? Depending on who is being compared with whom, it is at least arguable that they measure not culpabality but differences in the level of police activity and style of record-keeping between localities. ${ }^{71}$ The initial fallacy in the assump-

65. Instrtute for Defense ANALyses, TASK Force Report: ScIence and Technology, 223 (1967) [hereinafter SCIENCE \& TECHNOLOGY REPORT]. The report was made to the President's Commission on Law Enforcement and Administration of Justice, which cited the figure as 40 per cent. See Presment's Commn. on LAw Enforcement and Administration, The Challenge of Crime In a Free Society 237 (1967) [hereinafter Challenge of CRIME].

66. SCIENCE \& TECHNology REPORT, supra note 65 , at 224.

67. Databanks, supra note 30 , at 298.

68. Id. Also relevant in this context was the experience of New York City when it sought to update its police intelligence files on suspected extremists and found that a high proportion of the data stored was "cryptic" to the point of uselessness. See note 93 infra.

69. P. KEvE, supra note 6 , at 77 .

70. Indeed, whatever the number of citizens who have been arrested or convicted, self-reporting studies reveal that the majority of citizens, when given anonymity, will admit to the commission of a surprising number of illegal acts. See Chambers \& Nakaswa, On the Validity of Official Statistics: A Comparative Study of White, Black and Japanese High School Boys, 6 J. Research in Grime \& Delinguency 71 (1968); Erickson \& Empey, supra note 59.

71. Styles of police record-keeping can significantly affect the comparative appearance of individuals with identical histories. In general, the practices of different police departments with respect to reporting arrest records to the FBI and state databanks vary greatly. See Fishman, Expungement of Arrest Records: Legislation and Litigation to Prevent Their Use, 6 CrearINGHOUSE REv. 725, 728 (1973). Relevant areas in which police practices vary include: whether juvenile records are included on the "rap sheet" or kept confidential, see Ferster \& Courtless, The Beginnings of Juvenile Justice: 
tion that arrest records prove at least some degree of culpability is the premise that the police arrest individuals only to initiate criminal prosecutions. In fact, most studies of the arrest process have identified a number of factors motivating the decision to arrest that are wholly unrelated to a desire to initiate a criminal prosecution. Among these are the desires to maintain respect for the police, preserve an image of aggressive law enforcement, gather evidence through arresting the "usual suspects," enforce the arresting officer's concept of public morality, punish individuals suspected of other crimes, and protect the subject of the arrest. ${ }^{72}$ One authority has estimated that as many as one-third of the total arrests made each year are for trifling offenses, such as public drunkenness, in which no attempt is made to prosecute the accused. ${ }^{73}$ Most important of all, there is evidence that once an individual acquires even a single arrest record, he becomes "arrest-prone" and is statistically likely to acquire a lengthy record of subsequent arrests. ${ }^{74}$

An equally serious criticism of the probative value of arrest

Police Practices and the Juvenile Offender, 22 VAND. L. REv. 567, 571 (1969), whether alcoholism, similar disorderly conduct, and vagrancy arrests are memorialized, and the extent to which suspicion and dragnet arrests are made. In Menard v. Mitchell, 430 F.2d 486 (D.C. Cir. 1970), the court noted that in 1961 and 1962, over 6800 persons were arrested for "investigation" in the District of Columbia, of which about 6000 were released without charges of any kind ever being filed. 430 F.2d at 493 n.39. It has commonly been observed that the standards governing police discretion vary widely between different police departments. See, e.g., L. TrFfany, D. McInTYRE \& D. Rotenberg, Detrcion of Crime 38-40 (1967) [hercinafter L. TrFanY]. But equally important is the fact that police practices will vary even within a single city, with more aggressive policies being followed in ghetto and skid-row areas. Id. at xix. See also R. Nimmer, Two Million UnNecessary ARrests 36 (1971); Special Comm. on the YDl System of the Criminal Justice Coordinating Council, Staff Report: Juvenile Record-Keeping in New York City 77, July 1, 1971 (K. McMahon \& N. Dubler eds.) [hereinafter YD Study]. Partially as a result of such disparities in police practices, it has been estimated that 50 per cent to 90 per cent of American males residing in inner city areas have arrest records. See CHALI,ENGE OF CRrME, supra note 65, at 75 . Clearly, such statistics should not be taken at face value to indicate that urban males engage in more criminal activity than rural males. Indeed, one police administrator has estimated that as many as three out of four arrests may not have been based on the constitutionally required "probable cause" standard. See M. Hours, From ARREST to RELEASE 24 (1958), cited in Fishman, supra, at 727.

72. W. LAFAVE, ARREST 144-52, 437-82 (1965); L. Tiffany, supra note 71.

73. Morris, Politics and Pragmatism in Crime Control, 45 F.R.D. 183, 191 (1968). Morris estimates that arrests for drunkenness total approximately 2 million a ycar. See also R. Nimmer, supra note 71.

74. For a discussion of how individuals can become "arrest-prone" simply on the basis of a single prior arrest record, see Neier, Have You Ever Been Arrested, N.Y. Times, April 15, 1973, \& 6 (Magazine), at 16. According to expert testimony presented in Gregory v. Litton Systems, Inc., 316 F. Supp. 401 (C.D. Cal, 1970), modified, 472 F.2d 631 (9th Cir. 1972), a person who has been arrested once tends to accumulate additional arrests. The lifetime average for such a White male is 7 , and for a Black male, 12.5. Neier, supra, at 44. In particular, arrest records result from the police practice of "rousting," i.e., the process of "rounding up the usual suspects" in order to obtain 
records stems from evidence suggesting that the decision to record a police-citizen encounter in the form of an arrest record is highly discriminatory in that the status and demeanor of the subject are the critical variables. ${ }^{75}$ The pattern associated with the "suspicion" arrest exemplifies this phenomenon. In Gregory v. Litton Systems, Inc. ${ }^{76}$ a federal district court, noting the disproportionate percentage of "suspicion" arrests made in the case of Blacks, held that the use of arrest records by private employers was illegally discriminatory. ${ }^{77}$ Although Blacks represented only eleven per cent of the population, they accounted for twenty-seven per cent of the total arrests made annually, including forty-five per cent of "suspicion" arrests. ${ }^{78}$ Yet such arrests rarely, if ever, resulted in prosecutions. ${ }^{79}$

Statistics of this kind suggest that at the heart of the problem of who acquires an arrest record and who does not is the classic problem of the self-fulfilling prophecy: On the premise that the poor or members of minority groups are more likely to engage in criminal activity, police discretion is exercised more stringently against them, and the resulting disparity in arrest records between middle-income citizens and members of these groups is then cited as evidence of their past criminality in the event they ever reappear in the criminal justice system.

Yet, it is not only the poor or members of a minority group

leads to crimes. See Lemert, Records in the Juvenile Court, in ON RECORD, supra note 30 , at $380-81$. Thus, once one is identified as a suspect, repetition of the arrest pattern becomes foreseeable.

75. See Pilavian \& Briar, Police Encounters with Juveniles, 70 AM. J. SocroLogy 206 (1964). For official recognition of the discriminatory impact of such practices, see DEPT. of Health, Education, \& Welfare, Records, Computers and the Rights of Citizens 243 (1973) [hereinafter RECORDS, CoMPUTERS].

76. 316 F. Supp. 401 (G.D. Cal. 1970), modified, 472 F.2d 631 (9th Cir. 1972).

77. 316 F. Supp. at 403 .

78. 316 F. Supp. at 403. See also Carter v. Gallagher, 452 F.2d 315 (8th Cir. 1971), modified on other grounds, 452 F.2d 327 (8th Gir.) (en banc), cert. denied, 406 U.S. 950 (1972) (enjoining the consideration of arrest records in municipal hiring); Menard v. Mitchell, 430 F.2d 486, 493 \& n.38, 494 (D.C. Cir. 1970). Cf. W. LAFave, supra note 72 , at $287-88$.

In asserting that Blacks account for 45 per cent of all annual "suspicion" arrests, the Gregory court employed statistics from an abnormally high year. FBI records show approximate rates of 45.3 per cent for 1968, REPORTS 1968, supra note 63 , at 118 , 44.3 per cent for 1969, REPORTS 1969, supra, at 120 (presumably the most recent statistics available to the Gregory court), 29.8 per cent for 1970, REPoRTs 1970, stupra, at 131, 28.3 per cent for 1971, REPORTs 1971, supra, at 127, 35.2 per cent for 1972 , REPORTs 1972, supra, at 131, and 33.9 per cent for 1973, REPORTs 1973, supra, at 133. While the court's exact statistic was thus above the average for recent years, the court's conclusion that Blacks account for a disproportionate percentage of "suspicion arrests" was clearly correct.

79. One study cited by plaintiffs in Gregory showed that 98 per cent of "suspicion" or "investigation" arrests were never prosecuted. Neier, supra note 74, at 45 . 
who may be subjected to a false comparison by the use of arrest records. Studies have noted that wide variations exist in the style and extent of the records maintained between rural and urban police departments, and between middle-income and poverty-area police units. ${ }^{80}$ As a consequence, the danger exists that when dispositional authorities attempt to compare the pre-sentence histories of offenders on the basis of prior arrest records, they succeed only in comparing different styles of police record-keeping.

A final reason for expunging records of arrests not followed by conviction from the pre-sentence report is supplied by the "labeling" theorists. ${ }^{81}$ These theorists argue that once an individual is labeled a "delinquent" or "criminal" not only do future decision makers interpret the data before them to confirm and reinforce the preexisting label, but the labeled individual himself begins to assume the role attributed to him. ${ }^{82}$ Indeed, some experimental findings suggest that police records play a determinative part in the process by which the marginal delinquent matures into the role of a confirmed recidivist. ${ }^{83}$

80. Ferster \& Courtless, supra note 71, at 571.

81. Standard sources on "Iabeling theory" include V. EISNER, The DELINQueNcy LABer (1969); E. Lemert, Sociar Patholocy (1951); Faust, Delinquency Labeling: Its Consequences and Implications, 19 Crume \& Deurnguency 41 (1973); Payne, Negative Labels: Passageways and Prisons, 19 Crme \& Delinguency 33 (1973); Wheeler \& Cottrell, The Labelling Process, in Societx, Delinquency and Deringuent BEHAVIOR (H. Voss ed. 1970).

82. Payne, supra note 81 , at 34 (" $[\mathrm{P}]$ ositive and negative labels often occur before and lead to the behavior consistent with that label. ... [N] egative behavior [is created] by negative labels"). The dangers of premature labeling have also been recoge nized by the President's Commission: "Official action may actually help to fix and perpetuate delinquency in the child through a process in which the individual begins to think of himself as delinquent and organizes his behavior accordingly." Chatrengaz of CrIme, supra note 65, at 80 . See also E. ERIKson, IDENTITY: YouTh AND Crisis 254-56 (1968).

Labeling theorists have concentrated on the effect such "pre-delinquency" predictions have on the subject's self-image. Other commentators have emphasized the corresponding effect of such predictions upon the behavior of decision makers and have suggested that officials tend unconsciously to use such labels to distinguish the offender from the "ordinary" citizen and so deal with him more harshly. See note 107 infra and accompanying text.

The dangers of labeling have begun to receive some judicial recognition. In Mcrriken v. Cressman, 364 F. Supp. 913 (E.D. Pa. 1973), the district court found that the circulation of certain educational records relating to a drug prevention screening program created "the risk that the ... Program will operate as a self-fulfilling prophecy in which a child labeled as a potential drug abuser will by virtue of the label decide to be that which people already think he or she is anyway." 364 F. Supp. at 915. Based upon this and certain other dangers relating to record-keeping and the lack of adequate disclosure of the risks, the court enjoined the creation and circulation of the records at issue. $364 \mathrm{~F}$. Supp. at 919-20.

83. Sociologists Gold and Williams studied two groups, each consisting of 35 individuals, over an extended period. Both groups, chosen and "matched" from a sample of 847 individuals, had similar backgrounds and had committed similar crimes, but 
In defense of the present use of arrest records in sentencing, two arguments can be raised: first, the enlightened judge gives little, if any, weight to arrest-only entries; ${ }^{84}$ and, second, although a single arrest record may be meaningless, a lengthy string of such records is persuasive evidence of criminality. The first argument would seem to fall of its own weight-if "arrest-only" records are not considered by decision makers, their exclusion from the pre-sentence report should have little negative effect on legitimate law enforcement interests. Moreover, the premise that arrest records are inconsequential is inconsistent with the express numerical weighting given a prior arrest in prediction tables now used by dispositional authorities $^{85}$ and with the evidence of the devastating impact arrest records have when discovered by potential employers in the private sector. ${ }^{86}$

The second argument ignores the statistical evidence that a single arrest leads to multiple arrests because the individual becomes "arrest prone": If a subject's record shows only arrest entries and not convictions, this may indicate not recidivism, but a pattern of selective law enforcement. Moreover, if arrest reports are intermixed with

the members of one group had acquired police records while the members of the other group had not. Subsequently, members of the first group committed a greater number of crimes than members of the second group. As a result, the tentative conclusion was drawn that the experience of apprehension and the attendant labeling accultured the latter group to the role of delinquency. Gold \& Williams, National Study of the Aftermath of Apprehension, 3 U. Mrch. J. L. REF. 3 (1969). Cf. R. Rosenthal \& L. Jacobson, Pygmalion IN the Classroom (1968) (research involving student performance and official expectations).

84. See E. Green, Judicial Attitudes in Sentencing $44-45$ (1961). Edward Green's study, researched in 1957, was limited to practices in one court (the Philadelphia Court of Quarter Sessions). A statistically more sophisticated study undertaken by The Washington Law Review in 1971 of superior court judges in the State of Washington concluded that "the number of [the defendant's] prior arrests (particularly felony arrests) rather than convictions" was "an influential element" in the sentence assigned. See Comment, Discretion in Felony Sentencing-A Study of Influencing Factors, 48 WASH. L. REv. 857, 871 (1973). Indeed, no factor was identified as having a higher positive correlation to a decision to incarcerate than the number of defendant's prior felony arrests. $I d$. at 869 .

85. For a description of such a table see McGee, supra note 37 . While such tables are still infrequently used by sentencing judges (as opposed to parole boards), they appear to have been devised in part as an attempt to codify existing informal standards for the assessment of the offender.

86. See Schwartz \& Skolnick, Two Studies of Legal Stigma, 10 Social Prob. 133, 134-38 (1962) (showing, on the basis of a survey, that two-thirds of the potential employers questioned would not consider a prospective employee with a single arrest for assault even where the arrest was followed by an acquittal). While it is arguable that judges are able to ignore what private employers evidently cannot, the burden of proof clearly should rest on those making such an argument. In some jurisdictions, the sentencing judge is required in cases of serious crimes to receive a report on the offender's prior arrest record before passing sentence. See, e.g., N.Y. CRIM. Pro. LAW \$ 390.10 (McKinney 197I). 
records of convictions, exclusion of the arrest records would hardly blind the judge to the offender's past history. Only where the arrest reports stand alone without subsequent convictions are they likely to affect materially the assessment of the offender, and it is exactly in such a case that the inference of guilt is most unfair. ${ }^{87}$

c. Investigative and intelligence reports. Investigation of the defendant's activities for information that can be used to impute criminal behavior may encompass records even less reliable than arrest records. Police files contain large amounts of anecdotal and evaluatory information, gathered either in the course of investigations of specific crimes or by intelligence units. Probation guidebooks and official manuals exhort the probation officer to consult such sources to learn the defendant's "general reputation" in the community..$^{88}$ A recent survey of the criminal-history databanks maintained by state and federal authorities found a "virtually unlimited concept of what personal information should and would be collected" 89 in such files: "[I] nformation was regularly collected on such intensely private matters as the subject's finances, day-to-day movements, sex life, associates, and political beliefs." Menard $v$. Saxbe, the court of appeals found: "If the form is correct,

87. This does not mean that only convictions should be discussed in the presentence report. Some exceptions should be noted: the defendant may have confessed, or overwhelming evidence may have existed to support the charge, but the defendant was not prosecuted because of a more serious pending prosecution against him. In addition, some offenses, such as prostitution, may ordinarily go unprosecuted. What should be excluded is not specific information of involvement in a prior crime (if such information could be presented in reliable form and the defendant given an opportunity to rebut), but rather the neutral fact of the offender's prior arrest. Thus, information in organized crime files should be available if it can be substantiated. At present, with the exception of organized crime files, it seems unlikely that criminalhistory information is preserved with sufficient specificity to meet this standard.

88. Paul Keve, a leading authority on probation work, defends the practice as follows:

It seems to be generally accepted that the prior record section should include discussion of unofficially known delinquent or antisocial tendencies. In a great many cases you will hear tales of probable unlawful conduct which has not been officially tagged as such. The police will tell you of times that they have had strong reason to suspect your defendant but could not quite pin anything on him. A store owner, a neighbor, or a landlord may tell of times when your man cheated, fought, stole, or did other dishonest or disorderly things when no actual arrests were made. These need to be reported here and no apology needs to be made for the fact they are not official or completely verified reports.

P. KEVE, supra note 6 , at 77. Another leading probation manual recommends a similar procedure and advises the probation officer to ask local police officials about the defendant's general reputation. PRESENTENCE REPORT, supra note 6, at 11.

89. Databanks, supra note 30 , at 245.

90. Id. Similarly, the director of the New York State Identification and Intelligence System has reported that his agency had "carte blanche" to search the files of other state agencies for information it considered pertinent. Gallatti, The New York State Identification and Intelligence System, in INFORMATION TECHNOLOcY, supra note 34 , at 45 . 
the FBI will place in its criminal files virtually any information from local agencies arguably related to criminal activity." 11

Because such files are not primarily concerned with actual incidents (as arrest records at least are), the information and assessments contained in them have a tendency toward vagueness and are often not substantiated by specific detail..$^{22}$ On examination years later, much of this information can only be characterized as "cryptic." As in the case of arrest records, practices vary widely from jurisdiction to jurisdiction; 94 thus, the amount of adverse information recorded about an individual in such files may be as much a function of his exposure to the record-keeping process as it is a function of his own conduct. Methodologically, the information acquired is regularly recorded without editing or verification.

The latest and perhaps most ominous development in the area of police records has been the computerization of raw investigatory reports and the resulting creation of "status" codes. In their study of the Kansas City, Missouri Police Department, Professors Westin and Baker found that police intelligence data in that city had been compressed into single-word labels, such as "militant," "homosexual," and "mental." The initial impression received by an official using a computer terminal to ascertain an individual's background might thus consist of a pejorative and ill-defined conclusory label that was totally devoid of factual substantiation.

d. Juvenile records. Juvenile police records represent the ex-

91. 498 F.2d 1017, 1026-27 (D.C. Cir. 1974) (footnotes omitted).

92. Acknowledging these criticisms, the Fourth Circuit has ruled that allegations of criminal activity should not be included in a pre-sentence report unless referable to an "official record," apparently meaning arrest and conviction records. Baker v. United States, 388 F.2d 931 (1968). In Menard v. Saxbe, 498 F.2d 1017 (D.C. Cir. 1974), the court construed 28 U.S.C. \& 534 (1970) as precluding the FBI from maintaining in its central criminal-file records of encounters with law enforcement agencies that did not result in arrest. $498 \mathrm{~F} .2 \mathrm{~d}$ at 1029-30.

93. When in 1973, after pressure from civil liberties groups, the New York Police Department undertook to curtail its intelligence files on political extremists, it discovered that its "public security matters" files had burgeoned to include $1,220,000$ entries. After review, over 80 per cent of these names were deleted, because, according to First Deputy Commissioner William Smith, the references to them were either out of date or "so cryptic as to be useless." N.Y. Times, Feb. 9, 1973, at 70, col. 2.

94. Some cities, such as Milwaukee and Detroit, have regular procedures for the reporting of field interrogation reports, while others do not. See L. TIFFANY, supra note 71, at 73-80. See also LAFAVE, supra note 72.

95. Databanks, supra note 30 , at $80-87$, 98-99. In 1971, some 600 individuals were listed under the designations "militant," "activist," and "mental" in the files of the Kansas City Police Department. $I d$. at 85 . These files were accessible to law enforcement officials using a regional computer network that operated throughout much of Kansas and Missouri; during 1970, inquiries to this databank averaged 8000 a day. Id. at 81 . A related system is in operation in New Haven, Connecticut. Id. at 98. 
treme example of an all-inclusive approach to data collection. ${ }^{08} \mathrm{Be}$ cause pre-delinquency statutes eliminate the need for a triggering criminal offense, ${ }^{97}$ the individual police officer is generally free to record in the form of an arrest or similar record virtually any activity or attitude that he deems to be "misconduct" on the part of a juvenile. ${ }^{88}$ One commentator has estimated that about half the cases before the juvenile courts of a large metropolitan county involved behavior that would not be criminal in the case of adults. ${ }^{00}$ Yet the police files recording such instances of "misconduct" are not kept confidential (as are juvenile court records) and are generally available even years later to both juvenile and adult authorities. ${ }^{100}$

Symptomatically, the attempt to increase the scope of police records in the case of juveniles has been accompanied by a substantial deterioration in the quality of the data recorded. Efforts designed to identify the first sign of incident delinquency have resulted in the overloading of police record systems; more data is collected than can be intelligibly stored, assessed, or transmitted. An illustration is supplied by a 1971 official study of New York City's procedures for handling juvenile police records. Examining a system in which over 50,000 police reports (known popularly as "Y.D. cards") were annu-

96. For descriptions of the unique character of juvenile police records, see $A$. NzIER, supra note 30, at 48-56; Coffee, supra note 30; Lemert, Records in the Juvenile Court, in ON RECond, supra note 30, at 355; Note, Juvenile Police Record Keeping, 4 Couum. HUMAN Rights L. REv. 461 (1972).

97. Under a variety of descriptions-"person in need of supervision," "wayward child," "beyond parental control"-many juvenile court statutes make justiciable conduct that would not be criminal if committed by an adult. See S. Fox, supra note 46 , at $38-42$.

98. For a critique of the kinds of data justifiably recorded and preserved in police files under such statutes, see Note, California's Predelinquency Statute: $A$ Case Study and Suggested Alternatives, 60 CALIF, L. REv. 1163, 1170-74 (1972). See also Note, supra note 96 , at 467 .

One report, a detailed examination of the process by which juveniles acquired police records in New York City, stated that "[r]egardless of offense, if the child was disrespectful or defiant, he was more likely to receive a card." YD Study, supra note 71 , at 28. As that report emphasized, the absence of substantive standards governing the record-issuance decision invited selective law enforcement and made comparisons among juveniles based on such data highly unreliable. Id. at 71-79.

Several commentators have found that the pre-delinquency threshold of attention authorized by pre-delinquency statutes has particularly discriminated against the female juvenile, since it permits the police and the judiciary to focus on sexual activities that would be ignored in the case of a male. See, e.g., Gold, Equal Protection for Juvenile Girls in Need of Supervision in New York State, 17 N.Y.L.F. 570 (1971).

99. Morris, supra note 73, at 191. Neariy one-half of the over 50,000 Y.D. cards issued in New York in 1969 were "issued for behavior which, exercising discretion differently, might not have been administratively acted upon." Hanna, Zeitz \& Ferns, $A$ Qualitative and Quantitative Analysis of YDI Cards Issued in 1969 in YD Study, supra note 71, app. A, at 41 . For example, if a juvenile were disrespectful, he might receive a Y.D. card for a "dropped gum wrapper." YD Study, supra, at 30-31.

100. R. Dawson, supra note 6 , at 28-30. 
ally filed with respect to various forms of juvenile "misconduct," the study found that only 60 per cent of the records examined contained a specific statement of the alleged misconduct. ${ }^{101}$ Moreover, in order to simplify data handling, the information first recorded by the observing police officer was later condensed by record clerks into simplistic coded offense categories such as "harassment," "disorderly conduct," and "loitering." These vague categories often encompassed both serious and trivial offenses. ${ }^{102}$ When the data were disseminated by the police to probation officials, it was generally only this latter code that was released; often, in fact, only the number of past police reports on file would be requested by probation officials. ${ }^{103}$. As a result of this fragmentary transmission of data, the study concluded, a false equation was easily drawn by dispositional authorities: A "spate" of such reports was equated with a "trouble-oriented child,"104 although it was equally likely that these reports indicated only that police were keeping a "tight rein" on a specific area or that the youth's attitude "grated on the police."105 The result was "sloppy decision-making."

These findings underscore a problem that pervades the use of police records not leading to a conviction. Without providing distinctive information, such records reinforce what some criminolo-

101. Coffee, supra note 30 , at 583 . The author was attorney for plaintiffs in a lawsuit, Cuevas v. Leary, Civ. No. 70-2017 (S.D.N.Y., filed May 21, 1970), challenging the manner in which Y.D. data was disseminated to a variety of public agencies, including the probation department. Following the Y.D. Study (which was conducted by the Mayor's Criminal Justice Coordinating Council pursuant to a stipulation in Cuevas in order to investigate the principal allegations in the complaint), the lawsuit was settled on the basis of a final stipulation that, among other restrictions, denied access to Y.D. reports to probation officers conducting pre-sentence studies.

102. The nature of this distortion deserves a further word. Assume a police officer observes a group of teenagers, some of whom are annoying a girl. Because no prosecution is intended he files a report (known as a "Y.D. card") on each juvenile as a warning measure. A coding clerk would subsequently review the police officer's one-sentence summary and decide under which offense code to characterize the incident. Because the offense code chosen by him is often the only information transmitted to the probation officer preparing a subsequent pre-sentence report, his choice between an innocuous code (i.e., "throwing snowballs," "annoying a passerby") and more serious categories (i.e., "assault," "harassment," or one suggesting sexual molestation) could cause serious distortion. The New York study found that, as with arrest records, the results of follow-up investigations were seldom disseminated to the same persons who received the original report. Also, 18 per cent of all Y.D. cards issued were issued simply on the complaint of a citizen without police observation or investigation. YD Study, supra note 71 , at 28.

103. Cf. YD Study, supra note 71, at 54, 76-77. For a full discussion of the deficiencies in the Y.D. system's procedures for handling data, see Coffee, supra note 30, at 578-89.

104. Y.D. Study, supra note 71 , at 77 .

105. Id.

106. $I d$. 
gists have termed the "we-they fallacy": the idea that the offender is somehow markedly different from the ordinary citizen. ${ }^{107}$ Once enabled by such flawed records to conceive of the offender as either "sick" or a "habitual" criminal, the decision maker may then deal with him far more severely than he would an "ordinary" citizen.

\section{Educational Records}

Recent years have seen an explosive growth in the amount and scope of data that public school systems maintain with respect to their former pupils. ${ }^{108}$ Concomitantly, the accessibility of this data has been augmented by trends toward the computerization and centralization of educational records. ${ }^{109}$ While the school records of the offender do not appear to be consulted by probation officers with the same frequency as police records, probation manuals are unanimous in their insistence that the probation officer elicit the offender's "student behavior record" and any related "adjustment" data. ${ }^{110}$

In contrast to police records, the information found in school records is typically more intimate and anecdotal in content, ${ }^{111}$ and

107. Porterfield, The "We-They" Fallacy in Thinking About Delinquents and Criminals, in Befavioral Scienge and Modern Penology (W. Lyle \& T. Horner cds. 1973). See also Szasz, Some Observations on the Relationship Between Psychiatry and the Law, 75 AMA Archives Neurology \& Psychiatry 297 (1956).

This "we-they" distinction is also perpetuated by another common aspect of both juvenile police records and educational records: the tendency for such records to include "pre-delinquency" predictions. Often, based only on a trivial incident or on a tenuous assessment of the juvenile's personality, the probation officer, teacher, or police officer will include in his report a prediction that the juvenile is a "pre-delinquent" who should be watched closely. Thus, in Merriken v. Cressman, 364 F. Supp. 913 (E.D. Pa. 1973), the label "potential drug abuser" was applied to students, based largely on the highly unscientific methodology of distributing questionnaires that asked students and teachers to identify students who made "unusual or odd remarks" or who made "un usual or inappropriate responses during normal school activities." $364 \mathrm{~F}$. Supp. at 916 For a description of the various other means by which such predictions are made and memorialized, see $A$. NeIER, supra note 30 , at $36-47$.

108. See Goslin \& Bordier, supra note 34 . To understand the sheer volume of data concerning a student, gathered during his progress through the public school system, sce N.Y. State DePT. OF EDUc., Manual on PuPIL Records 3I (1967) [hereinafter N.Y. STATE MANUAL] (advocating a "record philosophy" of "uninterrupted accession" of information about the student from the beginning of his school life).

109. See Goslin \& Bordier, supra note 34, at 60; Privacy, The Collection, Use, and Computerization of Personal Data, Joint Hearings on S.3418, S.3633, S.3116, S.2810, S.2542 Before the Ad Hoc Subcomm. on Privacy and Information Systems of the Senate Comm. on Government Operations and the Subcomm. on Constitutional Rights of the Senate Comm. on the Judiciary, 93d Cong., 2d Sess. 195 (1974) (statement of S. Sallett, Senior Associate, National Comm. for Citizens in Education) [hereinafter Joint Hearings].

110. See P. KEvE, supra note 6, at 103 . Keve adds that no other information is as "vital" in the case of the juvenile defendant. Cf. Guides for SEntencing, supra note 6, at 77 .

111. Anecdotal records (i.e., a sketchy note by a teacher that Johnny seemed "dis. turbed" one morning, or an accusation that he "molested" a female student) present 
(at least in the case of the adult offender) far more stale. While such considerations do not appear to have given pause to probation professionals, educational authorities have begun to express serious reservations about the use of such data outside educational channels. They have pointed out that such records regularly contain highly tentative and contradictory personality evaluations of the student that may often include unverified or anonymous accusations of serious charges.112 One study has found that "thousands of children have been labeled as 'predelinquents' in school," and that such characterizations have been transferred to police criminal-information systems. ${ }^{113}$ Because of the unparalleled quantity of raw data contained in student records, it seems highly unlikely that either the probation officer or the sentencing judge is in a position to evaluate the information acquired from school files.

One national conference of educators, convened to consider the problems of school record-keeping, has strongly urged that under no circumstances should a student's complete file be made available without his informed consent. Under their proposed guidelines, access would be limited to "verified information of clear impor-

particularly acute problems in the case of educational data. Goslin and Bordier found that anecdotal records were permanently preserved (although not necessarily on the student's "permanent record form") in the vast majority of schools they surveyed. Goslin \&: Bordier, supra note 34 , at 7. In addition, in approximately 43 per cent of the cases they studied, juvenile court probation officers always had access to the student's entire file, including such raw data. Id. at 56 . Given the interest of probation manuals in locating the earliest date of "criminal activity" in an offender's past as an indicia of his potential for recidivism, see GuIDES FOR SENTENCING, supra note 6, at 38, such reports may well be given an interpretative gloss never intended by their authors.

112. See A. NEIER, supra note 30 , at 17-27. Neier cites instances of the same child being given absolutely contradictory personality assessments by different teachers. Id. at 21. The clearest statement of the dangers of describing the "whole child" in permanently preserved records is to be found in GuIDELINES FOR THE Collection, MAINTENANCe AND Dissemination of PUPIL Records (1970) [hereinafter PupLl-Record GuideLINES], a report prepared by a national conference of educators and related juvenile authorities convened under the auspices of the Russell Sage Foundation in 1969 to consider the "ethical and legal aspects of school record-keeping." The report emphasized the considerable range in the reliability of the data preserved by school authorities: "The total set of student personnel data extant in a school at a given time ranges from tentative uncorroborated reports on alleged student behavior to highly stable information. To illustrate: on one end of the continuum a memo may contain a report or allegation that a particular student molested a child, disrupted a class, or wept for several hours yesterday; at the other extreme records will show that a student has completed grade five .... These differing kinds of data require differing arrangements for security and access." $I d$. at 20.

113. Joint Hearings, supra note 109, at 195 (statement of S. Salett, Senior Associate, National Comm. for Citizens in Education). In Merriken v. Cressman, 364 F. Supp. 913 (E.D. Pa. 1973), the court expressed considerable doubt about the "confidentiality" of educational records that labeled certain students as "potential drug abusers," $364 \mathrm{~F}$. Supp. at 920 , and noted that such records might eventually come to the attention of law enforcement authorities. 364 F. Supp. at 916. 
tance,"114 and even such restricted access would be preconditioned upon the total file of available information being periodically evaluated, updated, and summarized by a committee of school professionals. ${ }^{115}$ This compromise makes sense and should serve as a model for the resolution of similar problems in the case of welfare data. ${ }^{\mathbf{1 1 0}}$ Neither welfare nor school records are as inherently pejorative as police records, and completely foreclosing access to this data might cut off a source of redemptive information. However, without internal editing and evaluation prior to release, the records of any agency possessing parens patriae powers are likely to be ambiguous and potentially misleading.

Unfortunately, in the Family Educational Rights and Privacy Act of $1974,{ }^{117}$ Congress has not followed this approach and has instead taken an all-or-nothing course. As a condition of the receipt of federal funds, all educational institutions must refuse to release student records when consent has not been obtained from the student or his family, ${ }^{118}$ unless the student's file is subpoenaed or its disclosure is ordered by a court. ${ }^{119}$ Because of the breadth of this exception, the Act promises to have at best limited relevance in the

114. PupIL-ReCord Guidelines, supra note 112, at 20. This category would include "systematically gathered teacher or counselor ratings and observations, and verified reports of serious or recurrent behavior patterns." Id. The guidelines limited the availability of even this information to agencies exercising a subpoena power, $i d$. at 26; yet it is difficult to see why the amount of data available to the probation officer should hinge on the procurement of a subpoena.

115. Id. at 20-21. Except for significant information that could be verified, "uneval. uated data" would be destroyed on an annual basis. Id. at 21-22. The conference further recommended that even verified information be purged once it becomes dated. Id. at 24. See also N.Y. State Manual, supra note 108, at 32-33. Recently, New York City has gone even further, providing parents with an opportunity to challenge and, if successful, expunge inaccurate data in school files. See N.X. Times, Jan. 21, 1973, § 4, at 11, col. 3 (late city ed.).

116. Welfare data may contain equally intimate information developed by caseworkers through home visits. Such data is generally obtained through "social service exchanges," which serve as clearing houses and keep track of an individual's contacts with all social agencies. Clearance of the offender's name through such an exchange is considered an essential procedure by the federal probation manual. PrEsENTENce REPORT, supra note 6, at 7-21. Welfare databanks appear to include an even greater breadth of information, much of it "soft" evaluative information, than do educational records, and welfare agencies seem willing in many instances to serve as information clearinghouses for other public agencies. See Note, Computerization of Welfare Recipients: Implications for the Individual and the Right to Privacy, 4 RuTGERs J. COMPUTERS \& L. 163, 170-76 (1974).

Moreover, welfare data, particularly information that an offender has failed to support his family adequately, may elicit strongly negative, moralistic reactions from some judges. See United States v. Holder, 412 F.2d 212 (2d Cir. 1969).

117. 20 U.S.C.A. \& 1232g (Supp. Feb. 1975).

118. 20 U.S.C.A. \& 1232g(b)(1) (Supp. Feb. 1975).

119. 20 U.S.C.A. § 1232g(b)(2)(B) (Supp. Feb. 1975). 
context of sentencing and parole. If the offender should dare to withhold his consent, the probation officer can simply request a subpoena from the sentencing court. A more intelligent approach to the problems of student records would have been to condition the receipt of federal funds upon the adoption of a program for the periodic review and updating of verifiable student data and the destruction of stale and unreliable records. Such a program would ensure that unreliable information, denied to most other decision makers, both public and private, would not remain available to the sentencing judge.

\section{Clinical Data}

Psychiatric information about the offender reaches the sentencing judge either pursuant to a referral to a court clinic ${ }^{120}$ or to an outside psychiatrist, or through the probation officer's discovery of pre-existing psychiatric evaluations in the files of public agencies. ${ }^{121}$ A dilemma, however, surrounds the use of clinical data: On the one hand, it has been observed that judges tend to greet psychiatric recommendations with an attitude approaching total deference. ${ }^{122}$ On the other hand, the consensus of recent commentators has been that the recommendations of the examining clinician are often based on little more than casual impressions or clinical hunches. ${ }^{123}$ Charac-

120. The existence of a specialized court clinic remains the exception rather than the rule. See Note, Sentencing: The Good, The Bad and the Enlightened, $57 \mathrm{KY}$. L.J. 456,485 (1969). For general descriptions of the operations of court clinics, see sources cited in note 35 supra. In addition to court clinics, specialized multi-state databanks for psychiatric records now exist; in general, probation officers have access to such records. See A. NEIER, supra note 30 , at 76.

121. Again, use of a pre-existing report raises the problem of staleness. Equally important, however, is the question whether the pre-existing report is addressed to the principal issue confronting the sentencing judge-the dangerousness of the defendant. The point has been repeatedly made that psychiatric data or evaluations tendered in answer to one question (e.g., competence to stand trial, or general social adjustment) are misleading if taken as an answer to a different question (e.g., potential for violence or recidivism). See Bendt, Balcanoff \& Tragellis, supra note 35, at 371; Rosenberg, Competency for Trial: A Problem in Interdisciplinary Communication, 53 JUDICATURE 316 (1970).

122. See, e.g., Vann, Pretrial Determination and Judicial Decision-Making: An Analysis of the Use of Psychiatric Information in the Administration of Criminal Justice, 43 U. DET. L.J. 13, 24 (1965). Professor Dawson has found that parole will seldom, if ever, be granted in the face of an adverse psychiatric report. Dawson, The Decision to Grant or Deny Parole, 1966 WASH. U. L.Q. 243, 253.

123. Consider the following evaluation by an experienced medical commentator: "Too often conclusions given are the result of impressions, intuitions and even hunches .... The most superficial details seem to suffice to support a decision." Meyers, The Psychiatric Examination, 54 J. CRIM. L.C. \& P.S. 431, at 431-32 (1963). See Roberts, Some Observations on the Problems of the Forensic Psychiatrist, 1965 Wrs. L. REv. 240, 243 (noting that "minimal psychiatric evaluation" is often presented as a full evaluation). 
teristically phrased in a style of exaggerated overstatement, ${ }^{124}$ these recommendations have exhibited a significant tendency to err on the side of overprediction. ${ }^{125}$

A variety of theories have been offered to explain the poor quality of the clinical reports provided to the courts. Medical commentators have been particularly critical of the reports submitted when the patient is referred (as typically occurs) to an outside clinician. ${ }^{120}$ The independent clinician usually has had little experience in the area of forensic psychiatry and even less in dealing with the members of the low-income and minority groups who populate the criminal courts. Accordingly, it has been suggested that outside clinicians are predisposed to diagnose such patients as abnormal merely because they differ significantly from the clinician's usual clientele. ${ }^{127}$

The relatively recent development of court clinics, designed to serve the judicial decision maker, has not abated criticism: On examination, observers have found that the constant pressure of heavy caseloads has led to the use of assembly-line methods and hasty interviews that have ultimately resulted in stereotyped descriptions. ${ }^{128}$

While medical commentators have stressed the need for minimal diagnostic standards to govern the professional adequacy of clinical recommendations made to courts, ${ }^{129}$ formulation of such procedures seems only a partial answer. Standing alone, such procedures are not in themselves sufficient because of both the tendency for the lay diagnosis by the sentencing judge to control later findings, and the communications-gap that frequently arises between the judge and the clinician. Each of these two factors merits a brief analysis.

Empirical studies have indicated that a low percentage of the offenders who come before the court are referred for psychiatric

124. See Comment, The Language of Involuntary Mental Hospitalization: A Study in Sound and Fury, 4 U. Mrch. J. L. REF. 195 (1970).

125. See Dershowitz, Psychiatry in the Legal Process: A Knife That Cuts Both Ways, Trial, Feb.-March 1968, at 29, 33; Meehl, Psychology and the Criminal Law, 5 U. RICH. L. REv. I, 26 (1970). Cf. Campbell, supra note 35, at 315; Settle \& Oppegard, supra note 16 , at 480 . For a survey of recent literature critical of the reliability of psychiatric diagnoses see Nietzel, supra note 21. (1965).

126. See, e.g., Heller, Mental Health and Criminal Behavior, 40 F.R.D. 417, 421

127. Id. at $420-21$.

128. Id. at 421. See also Kutner, The Illusion of Due Process in Commitment Proceedings, 57 Nw. U. L. REv. 383, 385 (1962); Rome, Identification of the Dangerous Offender, 42 F.R.D. 185, 186 (1966).

129. Dr. Heller, for instance, recommends the following as minimal standards: at least two lengthy interviews with the subject alone coupled with two joint interviews with the subject and his family, a battery of tests, and an evaluation conference in which all members of the clinical staff would participate. Heller, supra note 126, at 421-23. These standards appear to be seldom satisfied under current practice. 
study. ${ }^{130}$ The referral decision generally will be based on the judge's personal perceptions of what behavior is "normal," and such perceptions are unquestionably influenced by the social and economic background of each judge. Thus, it is not unreasonable to expect a disproportionate referral of offenders whose backgrounds are different from that of the typically middle-to-upper-income judge. On referral, the examining clinician will often receive the file containing the probation officer's preliminary findings and the police and educational records, the reliability of which has been criticized above. Indeed, the very fact of referral is apt to be interpreted by the clinician as persuasive evidence that the subject is mentally ill. ${ }^{131}$ Given the time and caseload pressures under which the clinician must operate, the initial lay diagnosis by the referring judge may prove decisive-the psychiatrist may perform only the descriptive function of attaching the appropriate clinical label to the alleged symptoms recognized by others. ${ }^{132}$

The clinician may have a far different conception of the signifcance of the label he has attached to the offender than does the court that receives his diagnosis. The literature of sentencing is filled with admissions by experienced and sensitive judges that they are uncertain as to the substantive meaning of much of the psychiatric information presented to them. ${ }^{133}$ Psychiatric terminology can be highly pejorative, carrying connotations that sound ominous to the layman. In addition, random surveys have shown that psychiatrists would apply labels indicating neurosis to a high percentage of the general population. ${ }^{134}$ Thus, dispositional decision makers

130. In 1969 only five per cent of all defendants in Massachusetts, a state that made early use of the court clinic, were referred for psychiatric evaluation. Campbell, supra note 35, at 292.

131. See also Mechanic, Some Factors in Identifying and Defining Mental Illness, 46 Mental Hygene 66, 69 (1962).

132. See also id. at 69-70; Dix, Acute Psychiatric Hospitalization of the Mentally Ill in the Metropolis: An Empirical Study, 1966 WASH. U. L.Q. 485, 509. While these studies focused on the civil-commitment process, it is likely that the diagnostician in the sentencing context typically assumes that referral by a public agency is conclusive of illness.

133. See, e.g., Murrah, The Dangerous Offender Under the Model Sentencing Act, 45 F.R.D. 161 (1967).

134. A study conducted in Manhattan in the early 1960's concluded that only $\mathbf{1 8 . 5}$ per cent of the individuals surveyed appeared free of significant symptoms of mental pathology. L. Srole, T. Langer, S. Michaels, N. Oppler \&. T. Rennie, Mental Health IN THE METROPOLIS 138 (1962). Arguably, such a study also demonstrates the tendency toward overprediction noted earlier. See text at note 125 supra. See also Lanham, Psychiatric Diagnostic Services, 54 F.R.D. 307, 309 (1968) (noting that 75 per cent of the patients referred to Saint Elizabeth's Hospital in the District of Columbia for diagnosis were classifiable as suffering from psychiatric disorders). See also text at notes $211-17$ infra. 
may be drawing false comparisons between the offender who is referred for examination and diagnosed as neurotic, and the offender who is not referred and is incorrectly assumed to be "normal."

In short, the current dialogue between clinician and sentencing judge leaves too much unsaid. ${ }^{135}$ Even if the report of the examining clinician were disclosed to defense counsel, it would remain impregnable because its basic assumptions, methodology, and theoretical foundations are seldom set forth. ${ }^{136}$ To ensure both judicial comprehension and an opportunity for effective rebuttal by defense counsel, the report must be communicated in a form that is "attackable."137 At a minimum, this would require both expansion and standardization of the psychiatric report to cover such areas as methodology, interview procedures, and a statement of the major diagnostic factors relied upon. In addition, it has been suggested that the initial report should include a comparative evaluation of the offender in terms of such categories as motives, capacity for self-control, need for treatment, and character assets. ${ }^{138}$ Upon disclosure of such a report, defense counsel should be permitted to submit written questions designed to inquire into the degree of certainty behind the diagnosis, the adequacy of the procedures employed, and to determine if any redeeming information known to defense counsel would alter the original diagnosis. This type of dialogue might be time-consuming, but, given the communications problems inherent in psychiatric reports, it seems to be the only alternative to the in-court cross-examination of the clinician.

\section{B. The Acquisition Stage: An Overview}

Several problems seem to reappear throughout the data acquisition stage, regardless of the type of information sought. Analytically, most of these problems can be grouped under one of three headings:

135. The chief communication problem faced by the clinician stems from the fact that he is seldom told what the court wants to know: Is he to evaluate competency to stand trial, the need for commitment, or latent tendencies towards violence? $C f$. Bendt, Balcanoff \& Tragellis, supra note 35 (discussing the protocols used to alleviate this problem in Massachusetts).

136. For example, it is generally recognized that there exist divergent schools of thought within the psychiatric profession that would produce different diagnoses on the same facts. See Roberts, supra note 123, at 244. Disclosure is without meaning or effect if such differences remain hidden.

137. Campbell, supra note 35, at 312. I rely on Campbell for much of the procedure recommended at this point. See also Bendt, Balcanoff \& Tragellis, supra note 35 (discussing the meed to create formal protocols to govern communications between courts and clinicians).

138. Campbell, supra note 35, at 318-20. 
(1) problems of data quality, (2) problems of data transmission, and (3) problems of parity.

\section{Problems of Data Quality}

In assessing the character of the data assembled during the presentence investigation, two deficiencies stand out. First, a significant amount of the information collected is irredeemably stale: Ancient police reports, records of juvenile misbehavior, and educational or clinical estimates of the adolescent personality are notable examples. All such information ignores the simple truth that, while individuals change over time, records remain static. The consequence is the appearance of a "Gresham's Law of Information": The bad information drives out the good simply because it is easier for the probation officer to rely upon any prior adverse record than to conduct his own independent investigation of the offender's current status. ${ }^{139}$

A second and more important deficiency is the absence of any recognition that a record may be adequate for one purpose and woefully inadequate for another. For example, unevaluated anecdotal data may be of legitimate use to school officials who maintain day-to-day supervision over the individual and yet be highly misleading when used by dispositional decision makers who are likely to be far less familiar with the individual.

In general, the picture is one of an elaborate data-gathering process in which no more than a limited effort is made to ensure the reliability of the information collected. . $^{140}$ The basic impression that emerges is of a pressure to extrapolate adverse conclusions about the offender from relatively tenuous informational resources. The reasons for this tendency are less certain. Some commentators have emphasized the basically accusatorial orientation that sometimes surrounds the pre-sentence inquiry ${ }^{141}$ and have suggested that the probation officer's outlook is distorted by his "role commitment" to law enforcement. ${ }^{142}$ An alternative explanation may lie in the ten-

139. YD Study, supra note 71, at 77. The study found that because recorded information was more "accessible," it was "easier and quicker to rely on what purports to be a past 'record' than to discover the relevant information from other sources, such as interviews with the defendant, his family and those who have continuing contact with him." Id.

140. For a similar conclusion, see R. DAwson, supra note 6, at 13.

141. A study of pre-sentence reports prepared for Michigan courts reached the following conclusion: "The approach is definitely investigative rather than diagnostic .... To some professional social workers who viewed this practice, the function of the investigators appeared 'prosecutory' with little effort to 'diagnose or make a case analysis ...." D. NEwMAN, supra note 6 , at 15 .

142. See Hazelrigg, An Examination of the Accuracy and Relevance of Staff Perceptions of the Inmate in the Correctional Institution, 58 J. CRIM. L.C. \& P.S. 204 (1967) 
dency of probation guidebooks and manuals to stress the investigative nature of the probation officer's job, while more or less explicitly suggesting that questions of data reliability and interpretation should be left to the dispositional decision maker. ${ }^{143}$

\section{Problems of Data Transmission}

The information collected in the data-gathering process is communicated to the court or parole board in an often incomplete and sometimes cryptic fashion. Again, this tendency seems partially attributable to a preoccupation with adverse information. An obvious example is the dependence upon FBI arrest records, which generally lack information as to subsequent dispositions. Use of such files without an attempt to obtain the ultimate disposition of the recorded incident evinces an intolerable indifference to the possibility of redeeming information. ${ }^{144}$ Even where dispositional information is readily available, some studies have detected a tendency for probation workers to focus only upon the accusatory information. ${ }^{145}$

A second factor responsible for the fragmentary character of the information presented to the dispositional authority is the pressure for compression of complex information into simplified evaluatory labels. In order to manage large quantities of information efficiently, data-handling systems (particularly when computerized) have a tendency to oversimplify by eliminating narrative detail. ${ }^{146}$ Classic ex-

(an empirical examination of the manner in which the "role commitment" of probation officers operating in a custodial setting produced "stereotyped perceptions" of the offenders with whom they dealt). See also M. FRANKEL, supra note 1, at 34.

143. Perhaps the leading example of this tendency is Paul Keve's book, The Probation Officer Investigates, which justifies tender of unsubstantiated accusations on the ground that in the aggregate they show the "aura of reputation" surrounding the offender. Keve advises that where the information consists only of rumor and hearsay, it should still be included, but should be carefully labeled as such. P. Keve, supra note 6, at 77. This compromise-i.e., include doubtful information but express skepticism-ignores the probability that the ultimate dispositional authority (be it judge or parole board) will assume that the probation officer has already determined that the information presented in the pre-sentence report is reliable before including it.

144. Obtaining up-to-date dispositional information from local courthouse or police files (at least those within the same state) would not seem to pose insurmountable obstacles and is apparently regularly accomplished in Arizona. See Lobel, The Arizona Total Criminal Justice Information and Communications System, 10 JuRIMETrics J. 95, 97 (1970).

145. Thus, the YD Study found that the results of follow-up investigations conducted with respect to a YD report were rarely communicated to, or requested by, probation officers. XD Study, supra note 71, app. A. See Coffee, supra note 30, at 58586. Judge Frankel has reported that probation officers tend to consult only the prosecution and not defense counsel in their pursuit of dispositional information. M. Franker, supra note 1 , at 28-34.

146. See Note, Protecting the Subjects of Credit Reports, 80 YALE L.J. 1035, 1041 n.29 (1971). Some commentators have pointed out that the problem of stereotypical 
amples of this form of unintended technological distortion were discovered in the Y.D. Study. Because of imprecise coding, incidents of widely varying character were often found to have been equated in their significance. A minor scuffle and a serious assault might each have been assigned the same vague, overlapping classification code of "harassment." Because, in general, only single-word codes were communicated to the probation officer, the information ultimately reaching the decision maker was usually imprecise. ${ }^{\mathbf{1 4 7}}$

In short, a consequence of overcompression can be the reduction of dissimilar events and incidents into basically fungible units of data. Once data are made fungible, the final step is simply to count the number of units. Several recent studies of juvenile court practices have thus discovered that probation workers often engage in a practice known as "frequency counting"-police reports on an individual are simply counted rather than examined. ${ }^{148}$ For example, a statistical analysis conducted as part of the Y.D. Study found a one hundred per cent correlation between the existence of four or more prior Y.D. reports on a juvenile and a decision by the probation officer to refer charges for court action; ${ }^{149}$ probation officers frequently would call police-record custodians and ask only for the number of prior reports on a juvenile. ${ }^{150}$ A 1972 study of Texas juvenile-court practices produced similar findings and concluded

coding did not originate with the computer, and is also prevalent in manual recordkeeping systems. See, e.g., Databanks, supra note 30, at 264-66. The basic point is that, whether manual or computerized records are involved, the attempt to transmit sensitive information in coded form generally involves the loss of important detail. Moreover, the translation of raw data into coded categories not only requires extreme condensation, but involves an important information-processing stage that is generally unsupervised that may involve the making of key evaluative decisions by persons who have no contact with the observer who provided the raw data.

147. Coffee, supra note 30 , at 583-85. The procedures used for the coding of Y.D. information are not unique, but rather present a paradigm of the problems involved in the transfer of information. Another example is the experience of the armed forces in using coded discharge numbers, known as "SPN" or "SDN" numbers, which were printed on a serviceman's discharge papers. Some 530 different numbers were used; such coded numbers might indicate that a serviceman was a "homosexual," a "bedwetter," or was discharged for such vague reasons as "criminalism," "unsuitability," or "sexual perversion." For example, in 1973, some 21,000 servicemen were discharged with coded numbers indicating that they suffered from "character or behavior disorders." The codes, though not disclosed to the former servicemen, were readily made known to public agencies and personnel departments of employers. No narrative descriptions of allegations supporting these stigmatizing descriptions were preserved. A. NEIER, supra note 30, at 78-80. Thus, rebuttal was effectively impossible.

148. Copeland, Juvenile Delinquency "Referrals" and Their Effect on Dispositions, 1 AM. J. CrRm. L. 296 (1972); Terry, The Screening of Juvenile Offenders, 58 J. Crum. L.C. \& P.S. 173, 180 (1967).

149. Coffee, supra note 30 , at 586-87.

150. Cf. YD Study, supra note 71, at 54, 76-77. 
that the number of prior police reports on a juvenile was the determinative factor in the court's decision to grant or deny probation, outweighing even the seriousness of the prior charges. ${ }^{151}$ Yet this study also found the same high level of error and ambiguity in the substantive content of the juvenile police reports as was detected in the Y.D. Study. ${ }^{152}$ Thus decision makers in both instances were left to count the number of prior reports against some administratively determined cut-off level in a system that blurred the distinctions between a police-citizen encounter and proof of guilt.

Such "frequency counting" is, however, only one example of distortion caused by overcompression of sensitive information. Another example, reported by Professors Westin and Baker, is police department "status codes" on individuals, which consist of terse conclusory labels, such as "militant" and "homosexual."153 Still another example is the use of single-sentence psychiatric evaluations. In all these practices there exists a process of gradual reification: first, a label is applied to a complex fact pattern, then, somewhere in the datatransmission process, the label becomes increasingly divorced from the factual summary until ultimately it alone is communicated to the dispositional decision maker.

\section{The Problem of Parity}

In practice, sentencing determinations appear to be basically comparative: Offender $X$ is measured against offender $Y$ in order to determine the appropriate disposition. But, because the theoretical goal of individualized sentencing presupposes that each individual offender is to be understood in his own unique terms, the presentence investigator is told to portray his subject in almost novelistic detail. ${ }^{154}$ The consequences of this divergence between theory and practice are important.

A theory that emphasizes maximum data collection may aggravate the danger of false comparisons by magnifying the disparities in exposure to record-keeping among individuals. Variations in the

151. Copeland, supra note 148, at 309-10. Copeland found that juveniles committed to institutions averaged 6.4 prior referrals, those placed on suspended commitment, 5.1 prior referrals, and those given only probation, 2.92 prior referrals. Id. at 307. See also Terry, supra note 148, at 180 .

152. Copeland estimated that 46 per cent of the "referrals" that dealt with actual violations of the criminal law (as opposed to behavior problems) were "unprovable." Copeland, supra note 148 , at 309 . The content of the referral reports ranged from a simple notation that a prior "referral" had been made to a lengthy statement. Id. at 305.

153. See text at note 95 supra. Cf. note 147 supra.

154. See note 158 infra. 
degree to which an individual's prior conduct will give rise to accessible records depend upon such factors as styles in record-keeping, geographic location, selective law enforcement, and the tendency of benevolent institutions to pre-select certain individuals for more careful observation. Unless the subjects of the inquiry all share an equal exposure to record-keeping, individuals with identical pasts may appear differently. Thus, fairness to the record-prone individual requires a normative theory that subordinates the goal of acquiring all available information to the need for parity. In turn, the goal of parity requires standardization of the types of information brought to the attention of the decision maker. ${ }^{155}$ So long as the reality of sentencing practice emphasizes the comparative differences among offenders, the uniformity and evenness of the pre-sentence inquiry are critical variables. Unfortunately, as we shall next see, these are the very variables ignored by the current dominant approach to the processing of dispositional information.

\section{The Assessment of Sentencing Information}

Beyond the problems relating to the quality of the data included in the pre-sentence report is the overriding issue whether the present pre-sentence report system constitutes an effective and impartial means for the communication of essential information from the probation department to the dispositional authority. In this section, we will look first at the dominant approach to the presentation of sentencing information, the social worker's "case attribute" method, and then at currently utilized statistical and clinical alternatives.

\section{A. The Case Attribute Method}

In essence, the "case attribute" approach analogizes the probation officer to the social worker investigating a client. In the belief that facts which may initially seem irrelevant will possess clinical significance when viewed in the proper context, the case attribute approach asks the pre-sentence investigator to develop and present

155. Clearly, it would be irrational to allow the comparative appearance of two offenders to depend on the relative zeal of their respective probation officers in ferreting out prior instances of misconduct. Yet exactly the same "uneven" inquiry results where individuals are investigated equally, but do not share the same degree of exposure to record-keeping. Explicit criteria need to be developed to exclude nonessential adverse information that is not approximately equally accessible with respect to all offenders. Rather than prejudice the record-prone individual, it seems fairer to disregard most pre-conviction data, such as juvenile police reports and arrest records, on the ground that such information is fundamentally "uneven," even though these records might possess diagnostic significance for the analysis of a single offender, standing alone. 
all the " attributes" of his client in a full-scale profile. ${ }^{150}$ At its worst, this approach amounts to little more than a cut-and-paste technique in which every available report or document concerning the subject is quoted without regard to internal consistency. ${ }^{157}$ More typically, the probation officer is asked to present a consistent view by adopting a novelistic approach to his subject. Standard probation manuals exhort the probation officer to portray his subject in vivid, fleshand-blood terms in order to make the offender "come to life."158

It is highly questionable whether the average probation officer is competent to make the subjective evaluations required by this technique. ${ }^{159}$ According to Judge Marvin Frankel, a "simplistic conventionality" permeates the typical pre-sentence report: If the offender attends church, he is assumed to be a safe risk; if he lives with a woman to whom he is not legally wed, he is assumed to be amoral and a higher risk. ${ }^{160}$ Similarly, the probation officer accepts

156. For a fuller definition of the "case attribute" system see W. REckLEss, supra note 37, at 97-99. Professor Dawson has found that this same desire to collect "every piece of relevant information" about the offender, regardless of whether such information is regularly available about other offenders, also persists at the parole board level. R. DAwson, supra note 6, at 251.

157. G. Grardini, The Parole Process 113-14 (1959). Mr. Giardini, Superintendent of Parole Supervision for the Pennsylvania Board of Parole, noted that a result of such unintegrated pre-sentence reports is the frequent inclusion of contradictory statements.

158. The following representative advice comes from the official federal manual on the preparation of pre-sentence reports: "[F]acts alone do not give an account of a living person-his character and personality in action. People in the report must come to life. Instead of giving an accumulation of cold facts the report should rather present a true, vivid, living picture of the defendant." PRESENTENCE REPORT, supra note 6, at 3. This exhortation to deal "vividly" with what are highly subjective concepts in order to make the portrait of the offender "come to life" has often been repeated in remarkably similar language. See P. KEvE, supra note 6, at 77; Kennedy, The PreSentence Investigation Report Is Indispensable to the Court, FED. Probation, AprilJune 1941, at 3; Sharp, supra note 6, at 484; Wallace, supra note 26, at 437. For a skeptical view of whether the subtle nuances sought by such recommendations are meaningful to the decision maker, see Glueck, supra note 11, at 16.

It cannot be ignored that another reason for the popularity of the case attribute system is the professional enhancement it gives to the status of the probation officer. Its insistence that the probation officer perform the roles of clinician and novelist in describing the offender elevates the probation officer from clerical to "professional" stature.

159. Some of the pre-sentence report deficiencies noted by critics may also result in part from the inability of many probation officers to devote the amount of time to a report required by the case attribute approach. The President's Commission has recommended that a full-time probation officer handle no more than ten pre-sentence reports a month. TASR FORGE REPORT: CORRECTIONS, supra note 2, at 18. As the report points out, many probation officers handle substantially more than this number each month.

160. M. FRANKEL, supra note 1, at 34. With obvious restraint, Dr. Gaylin has expressed similar criticism: "In actuality, pre-sentence reports are not very good. Those that I have inspected would not have been very highly valued in a department of 
at face value charges passed along to him by the prosecutor, while seldom, if ever, consulting defense counsel. ${ }^{161}$

A more fundamental criticism of the case attribute approach has come from the social scientists who have attacked the assumption that the inclusion of all accessible information about the offender assists analysis. They have argued that the vast array of detail frequently included in dispositional reports chiefly serves to confuse decision-making. ${ }^{162}$ The Task Force on Corrections of the President's Commission summarized the essential elements of this critique:

Presentence reports in many cases have come to include a great deal of material of doubtful relevance to disposition in most cases. The terminology and approach of reports vary widely with the training and outlook of the persons preparing them. The orientation of many probation officers is often reflected in, for example, attempts to provide in all presentence reports comprehensive analyses of offenders .... In many cases this kind of information is of marginal relevance to the kinds of correction treatment actually available or called for. Not only is preparation time-consuming, but its inclusion may confuse decision-making. ${ }^{103}$

When the decision maker is seeking to make comparative judgments about offenders, overinclusion of information poses a considerable danger to those defendants who have received a relatively

sociology." W. GayLIN, supra note 6, at 99. For studies critical of the probation officer's ability to perceive impartially the offender, see sources cited in notes 141-42 supra.

161. M. FrankEx, supra note 1 , at 28. Similarly, there is evidence that correctional and probation officials rarely listen to or accept the offender's version of certain critical facts. See Project, supra note 58, at 835-37.

162. In Sentencing as a Human Process, Professor Hogarth concluded after considerable empirical research that the pre-sentence report was often not an "effective medium of communication" because of its length and complexity. J. FiocArTH, supra note 6 , at 390 . He writes: "The difficulty arises from the fact that the human mind has a very limited capacity to deal with a large body of information." Id. at 391. Professor Dershowitz has reached a similar conclusion, Dershowitz, Character Tests for Law Students, 58 A.B.A.J. 815, 819 (1972), as has the President's Commission. TASK FORCE REPORT: CORRECTIONs, supra note 2, at 14. As a computer scientist has phrased it, decision makers suffer not so much from the lack of relevant information as from an "overabundance of irrelevant information." Ackoff, Management Misinformation Systems, in InFormation TEChNOLOGY, supra note 34, at 264, 265. Cf. Stuart, Aftermath of Apprehension, Social Scientist's Response, 3 U. MrcH. J. L. REF. 13, 21 (1969).

163. TASK FORCE REPORT: CORREctions, supra note 2, at 19 (emphasis added). This theme of confusion because of informational overload appears to have been corroborated by a number of empirical studies. See W. RECKLEss, supra note 37, at 751; Schuessler, Parole Prediction: Its History and Status, in REAdINGS IN CRIMINOLOGY AND PENOLOGY 598 (D. Dressler ed. 1964) [hereinafter READrnGs]. In one of the better known of these experiments, experienced parole administrators were unable to outperform either inexperienced laymen or random selection when seeking to predict future parole violators on the basis of undigested case summaries. See Grant, Various Uses of Prediction Procedures, in READINGs, supra, at 607, 608-10. 
more thorough examination of their past lives. While differences in the depth of the pre-sentence inquiry may have a decisive impact on the relative appearance of different offenders to the sentencing judge, this variable of comparability has been ignored by the case attribute technique. A study by sociologist Yona Cohn ${ }^{164}$ of presentence reports submitted in a New York court illustrates both the inadequacy of the pre-sentence report as an instrument for the comparative evaluation of offenders and the discretion given the probation officer to introduce or withhold significant data. Cohn discovered that certain findings in the pre-sentence report, such as the probation officer's evaluation of the offender's personality and his home life, were more important determinants of disposition than the severity of the actual offense. Yet, in a high proportion of the several hundred cases Cohn surveyed, the probation officer's report was silent on these factors. ${ }^{165}$ In summary, she found a general spottiness evident in the pre-sentence reports: A probation officer might focus on a sensitive factor in one case, and then ignore it altogether in the next. ${ }^{168}$ As a result, she concluded that "the probation officer was unaware of the importance of the criteria he was actually using." 107 The unevenness noted by Cohn flows in part from the emphasis placed upon a novelistic approach-word pictures of each individual defendant are inherently unstandardized and noncomparable. ${ }^{168}$

164. Cohn, Criteria for the Probation Officer's Recommendations to the Juvenile Court Judge, 9 Crime \& DeLinquency 262 (1963).

165. Id. at 268-69.

166. $I d$.

167. Id. at 273-74. Another study conducted in Northern California has also concluded that probation officers tend to communicate information in highly individual ways, each tending to base his recommendations on different types and amounts of information. Carter, The Presentence Report and the Decision Making Process, $4 \mathrm{~J}$. Research Crime \& Delinguency 203-11 (1967). Cf. J. Hogarti, supra note 6, at 249. The study further concluded that, once a tentative decision was reached by the probation officer, the officer seemed to utilize only such additional data in reaching a recommendation as confirmed his original conclusion. See notes 171, 174 infra. Cf. J. HogarTH, supra, at 249. A similar study by British researchers (in which a representative sample of probation officers was tested to see which of various pre-sclected items of information would influence their recommendations) also reached the disturbing conclusion that the "way in which probation officers seek and utilize information in the course of making decisions is more a characteristic of the officers rather than the nature of the information." Wilkins \&: Chandler, Confidence and Competence in Decision-Making, 5 BrIT. J. Criminol. 22-35 (1965), quoted in R. Hood \& R. Srarks, Key Issues in Criminology 164-67 (1970). Because the sentencing judge has been found to rely heavily upon the recommendations made by the probation officer, see note 24 supra, it has been suggested that variations in sentencing may frequently reflect variations in the style and approach of different probation officers. R. Hoon \& R. SPARKs, supra, at 165 .

168. See also TASR FORCE: CoRRections, supra note 2, at 15. One critic of the case attribute system has suggested that its entire process of information-gathering is mis. 
Ultimately, the central question involves the behavior of the sentencing judge or other dispositional decision maker: What is their reaction to the wide scope of data communicated to them by the case attribute approach? Only recently, with the publication of Sentencing as a Human Process by the Canadian sociologist John Hogarth, has this question been directly addressed. Hogarth's findings, based on the most extensive empirical investigation of the sentencing process yet conducted, are striking. First, he rejects the " $a$ priori hypothesis that the pre-sentence report will lead a magistrate to come closer to the probation officer's view of the case."169 In fact, not only do many judges fail to assimilate its contents, but they often react negatively to it, and "in doing so obtain a picture of the offender which is opposite to that communicated to him by the probation officer."170 According to Hogarth's findings, judges tend to interpret the data contained in the pre-sentence reports selectively in order to support whatever preconceived attitude they bear toward the offender.171 Thus, because each judge is apt to react differently to the same data, he concludes, "The notion that magistrates can sentence better if they know 'all about' offenders has been shown to be a myth."172 In the hands of a judge with a punitive penal philosophy, the pre-sentence report serves not as a means of individualizing justice, but as a device "to justify sentences that would appear punitive if based solely on the offense."173

guided because it ignores the needs of the decision maker: "Correctional agencies, like other social agencies, have two main concerns: keeping case records and making decisions. Both represent ... expenditures of time and money, but the two activities have little influence on each other. The information-collectors are busy describing the whole person. The decision-makers are busy trying to cope with a multitude of pressures in a field where little systematic study or body of facts is available." Grant, supra note 163 , at $609-10$.

169. J. Hogarth, supra note 6 , at 261.

170. $I d$.

171. Hogarth states: "It seems that the degree of pathology seen in certain areas of the offender's life is associated with selective interpretation of data in the interests of resolving conflict which may arise between the facts of the case and what the magistrate would like to do by way of sentence ... . The attitudes and penal philosophies of magistrates appear to function as filters through which information is perceived selectively." Id. at 276. Professor Hogarth's findings seem to confirm a hypothesis offered by Professors Hood and Sparks of Cambridge University, who earlier opined: "We suggest that it is primarily differences in the way in which information is categorised and perceived, especially in cases of intermediate gravity where there is obviously more room for disagreement, which explains disparity in sentencing." $R$. Hood \& R. SPARKs, supra note 167 , at 159.

172. Id. at 390.

173. Id. at $390-91$. Judges may have a tendency to use psychiatric evidence to enable them to mete out strong sentences about which they would otherwise feel guilty. Cf. Szasz, supra note 107, at 310-13. For a discussion of the process by which the probation officer may help the judge to rationalize a sentence that the judge already wishes 
Hogarth's conclusion that the pre-sentence report is seldom "an effective medium of communication" should not be surprising. His specific findings concerning the selective use of sentencing data have been foreshadowed by a generation of more generalized research by psychologists who have studied the cognitive process by which conflicting items of information are resolved. Basically, they have agreed that decision makers interpret data so as to emphasize those items of information that reinforce their preconceptions and minimize those items that conflict. ${ }^{174}$ This view is applied by Hogarth to the sentencing context in the following manner: The sentencing judge forms an initial impression of the defendant either at trial or immediately after the issue of guilt is determined; at this point, he has identified in his mind the principal issues that will affect his dispositional decision. Only thereafter is he given the pre-sentence report, at a time when his judgment is already substantially predetermined. ${ }^{175}$

In summary, the case attribute technique is an impressionistic approach, the methodology of which is ill-suited to any practical evaluation of the relative risks that different offenders pose. Although it has few proponents among those who have studied it in operation, it remains (and is likely to remain) the predominant technique for the communication of dispositional data. Why? Chiefly because it alone offers the participants the illusion that they are dispensing a truly individualized form of justice. ${ }^{176}$

to impose, and of the possibility that the probation officer may attempt (consciously or unconsciously) to anticipate the judge's own attitudes in his pre-sentence report, sec A. Blumberg, Crmminal Justice 124-25, 137 (1967), quoted in R. Hood \& R. Sparks, supra note 167 , at 166 .

174. Both the theory of cognitive dissonance, as postulated by Professor Festinger, and several related theories (the influence of which are acknowledged by Professor Hogarth) suggest that the human mind has an innate drive to maintain consistency between its pre-existing attitudes and the information it receives. Consequently, the mind interprets information selectively so as to conform as much as possible to its pre. existing attitudes. See L. Festinger, A Theory of Cognitrve Dissonance (1957); C. Hovland, I. Janis \& H. Kelly, Communication and Persuasion (1953); M. Roreach, The Open aNd Closed Mind (1960). For an excellent recent summary, sec H. Schroder, M. DRtver \& S. Streufert, human Inforatation Processing (1967).

175. J. Hogarth, supra note 6, at 229-31.

176. Gordon Tullock has written that the rehabilitation model of the correctional process persists in the face of the mounting critical evidence that it simply does not work chiefly because it permits society to maintain a "pleasant" image of the correctional system. Tullock, Does Punishment Deter Crime?, 36 Pus. INTEREST 103, 110 (1974). A quite similar observation has been made by Dr. Gaylin, who writes that the continued belief in the "conventional kind of treatment" of the offender "represents that massive denial that occurs with frustration." Rather than face despair, society, in his view, insists on pretending that an "inadequate" system is "effective." W. GaYLIN, supra note 6 , at 100 . 


\section{B. The Categoric Risk Approach}

If the major deficiency of the case attribute method is its unscientific dependence on an impressionistic portrayal that cannot be compared with other such reports, an obvious alternative would be to develop a standardized rating system. Typically, proponents of such an approach have urged that it be accomplished as follows: first, on the basis of the statistical relationship between a given criterion and tabulated recidivism rates, preselect the criteria that are to be employed; second, collect only such data as bears on the chosen criteria; and finally, measure each offender in terms of these uniform standards.

The essence of this approach-the "categoric risk" techniqueis to assume not that the facts of each case are unique, but that the risk of recidivism is relatively uniformly distributed within groups sharing similar characteristics. ${ }^{177}$ As a result, an individual's risk level is to be measured on the basis of his membership in certain "population groups." Methodologically, this involves the creation of a prediction table that classifies the offender on the basis of various social, educational, psychiatric, and criminal-history categories. Each category carries a risk level that has been predetermined on the basis of empirical studies of the subsequent careers of selected offenders who shared the same demographic characteristics. ${ }^{178}$ Social scientists have long argued that the cumulative efficiency of using multiple predictive factors and then reducing the results to a numerical ranking would consistently outperform the "separate, isolated impressions" that dispositional decision makers gain from reviewing the merits of each case. ${ }^{179}$

177. Stuart, supra note 162, at 21.

178. For an excellent capsule description of the methodology and issues surrounding the use of categoric risk prediction systems, see R. HOOD \& R. SRARKs, supra note 167, at $119,182-86$. The authors emphasize that the accuracy and reliability of prediction tables "depends entirely on the quality of information which is available about offenders," which they find to be "very low," id. at 85, largely because of haphazard record-keeping and the uneven availability of information. See also Katkin, supra note 6 , at 21 .

179. See W. REckLess, supra note 37, at 751. See also M. FRANKEL, supra note I, at 113-14; M. Paulsen \& S. Radish, Criminal Law and Its Processes 113-14 (1962).

While prediction tables do outperform the results of decision-making based on clinical evaluations or intuition, the expectations of their proponents have generally not been confirmed when the results obtained from such tables have been reviewed by independent researchers. In 1971, the British Home Office sought (as an intended prelude to implementing a probation-prediction system) to analyze systematically the results obtained by all major earlier attempts. That study reluctantly concluded: "[O]ne of the chief reasons why, although many prediction tables have been constructed and much has been written about them, they have still been put to relatively little use may be that for practical purposes their real predictive power is usually rather low." F. Simon, Prediction METhods In Criminology 14 (1971). After 
In assessing a prediction table, three questions must be asked. First, what is really being measured? Second, does this system discriminate unjustifiably against those who are either young, members of minority groups, or poor? Third, is it in any event justifiable to assign individuals to prison on the basis of morally neutral characteristics that are shared by a great number of individuals who have committed no crime? These questions come into clearer focus once we examine a typical prediction table. The following "base expectancy table" has been reported to be in current use by the California Youth and Adult Corrections Agency and has a maximum score of seventy-six; a score of fifty-three or above represents a seventy-five per cent chance of success on parole: ${ }^{180}$

Factors Points

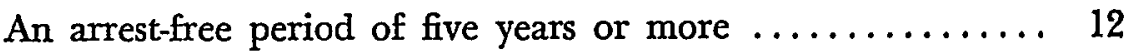

No history of opiate use $\ldots \ldots \ldots \ldots \ldots \ldots \ldots \ldots \ldots \ldots, 9$

Two or less jail commitments $\ldots \ldots \ldots \ldots \ldots \ldots \ldots \ldots \ldots, 8$

The charge is not checks or burglary ............. 7

No family criminal record $\ldots \ldots \ldots \ldots \ldots \ldots \ldots \ldots \ldots, 6$

No alcohol involvement related to offense $\ldots \ldots \ldots \ldots \ldots 6$

Not first arrested on auto theft $\ldots \ldots \ldots \ldots \ldots \ldots \ldots \ldots \ldots, 5$

Six or more consecutive months of work for one employer .... 5

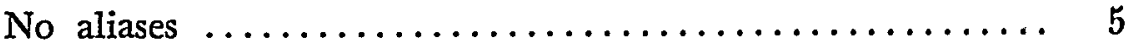

First imprisonment under this serial number $\ldots \ldots \ldots \ldots \ldots, \mathbf{5}$

Favorable living arrangements $\ldots \ldots \ldots \ldots \ldots \ldots \ldots \ldots, 4$

Few prior arrests (zero, one or two) $\ldots \ldots \ldots \ldots \ldots \ldots \ldots, 4$

On a brief inspection, it is evident that the foregoing scale can produce some strange results: an alcoholic without a single prior arrest who passes bad checks could start off behind a previously convicted murderer. Similarly, a first offender (in terms of prior convictions) who has a prior history of arrests (including an arrest

reviewing the results of some 40 prediction systems, the report found that it was "rare to achieve a correlation of more than .40 between the predicted and observed probability of recidivism," id. at 156, and that while such tables could be used effectively to select "small groups of good or bad risks," $i d$. ., "the accumulated evidence suggests that for a large middle range of offenders, it is unlikely that future criminal behavior can be predicted to a useful extent from a knowledge of past history." Id. at 158. Such research, it concluded, had reached "a point of diminishing returns." Id.

180. McGee, supra note 37, at 195. For other examples of sentencing tables, see Institute on Sentencing for United States District Judges, 35 F.R.D. 381, 403-04 (1964); Stern, Courts and Computers: Conflicts in Approaches and Goals, 58 JUdicsture 222, 226-27 (1974); Vondracek, Urban \& Parsonage, Conceptualization and Development of a Computer Assisted Diagnostic and Prescriptive System for Juvenile Delinquents, 4 RuTGERS J. CoMputers \& L. 86 (1974). 
for auto theft), and a relative with a criminal record, could already be below the important seventy-five per cent success threshold.

The obvious importance attached by this system to prior arrests, coupled with its relative indifference to convictions, indicates that the table ultimately measures not the dangerousness of the offender, but the relative likelihood that the individual will later come to the attention of the criminal justice system. Thus, the alcoholic who writes bad checks, and thus poses a relatively minor threat to society, but who is more susceptible to being apprehended than other offenders, may be evaluated more severely than an offender previously convicted of violent crimes. Although factors such as prior arrests or relatives with a criminal record may not indicate individual culpability, they do serve as a fairly accurate measure of whether an individual will again come to the attention of the criminal justice system, in part, because these same factors influence future police discretion.

Efforts to design a predictive scale that can identify violent or dangerous offenders have not succeeded in producing satisfactory statistical relationships. ${ }^{181}$ For a number of critics, the attempt to discover criteria that will identify "dangerousness" represents the pursuit of a "non-question"- an attempt to define an inherent state that they doubt exists. ${ }^{182}$ In their view, external factors such as the rate of unemployment or intense situational pressures are far more likely to determine whether an individual becomes a recidivist than any internal character deficiency. ${ }^{183}$

Even more important than the question of what the statistical profile can or does measure is the fundamental question of the fairness of its use. The most valnerable aspect of prediction tables is their tendency to assign much higher risk levels to offenders who are either young, Black, or poor, ${ }^{184}$ as opposed to those who are middle-aged, White, or middle-class. Many of the factors used in

181. See McGee, supra note 37, at 196. See also Murrah, supra note 133, at 168. A recent summary of the lack of success encountered by researchers attempting to predict "dangerousness" is set forth in Morris, supra note 16, at 1164-73. See also Diamond, supra note 16. Recently, one federal judge has even found the term "dangerous" as used in the federal dangerous offender statute, 18 U.S.C. 3575(f) (1970), to be unconstitutionally vague. See United States v. Duardi, 384 F. Supp. 874, 885-86 (1974).

182. See generally Morris, Politics and Pragmatism in Crime Control, 45 F.R.D. 183, 194 (1968); Diamond, supra note 16, at 447-52. Cf. STRUGGLE FOR JUSTICE, supra note 2 , at $78-82$.

183. See Schuessler, supra note 163 , at 606 .

184. Proponents of the prediction table have frankly admitted that it adversely affects offenders in these categories. See G. GIardin, supra note 157, at 138; W. RECKLEss, supra note 37, at 98.99. But see Project, supra note 58, at 877 n.329. 
these tables (for example, level of education, period of unbroken employment, legal status of relatives) distinguish the fortunate from the unfortunate, but involve no element of personal culpability. Indeed, at least one table in use places significant weight on "economic information," thus expressly separating the poor from the rich and middle-class. ${ }^{185}$ While it would certainly be unacceptable to assign a higher risk level according to race, such criteria indirectly approximate this result. ${ }^{186}$

Prior to 1973, prediction tables constituted at most a footnote to any discussion of the problems of dispositional decision-making.

185. See Stern, supra note 180, at 226-27. The "behavior profile index rating" table described by Stern, recently instituted in juvenile court to determine pre- and posttrial incarceration, also penalizes the juvenile if a neglect petition has even been filed against his parents. A similar theme of "guilt by association" runs through those tables, such as the California table discussed in the text at and following note 180 supra, which penalize the offender if a relative has a criminal record. Outside the context of sentencing, courts have been quite willing to find unconstitutional any practice by a state agency that involves "guilt by association." See, e.g., St. Ann v. Palisi, 495 F.2d 423 (5th Cir. 1974) (finding unconstitutional the suspension of a student because of actions of a relative). For a further discussion of this case, see note 196 infra.

186. In the development and testing of the United States Board of Parole's Salient Factor Score, the status of being Black was found to correlate with many of the social and economic factors used by the Board to predict parole failure. Project, supra note 58, at 877 n.329. The experimenters who designed the Salient Factor Score decided not to include race as a factor in classifying offenders partially on "ethical" grounds and partially on "mathematical" grounds (since there was a "substantial" degree of overlap between race and the other criteria chosen). Id. However, if sociocconomic factors having a known high correlation with membership in a particular racial group are used, the result achieved will be substantially the same as if race were itself used as a factor. In reply to this, it has been argued that the Salient Factor Score does not have a discriminatory impact in terms of prison populations since both the highest risk and lowest risk groups have apparently somewhat more White than Black members on a proportional basis (while Blacks are disproportionately present in the middle groups). Id. Two points must be made with respect to this argument: First, it is at least arguable that the issue whether a screening device has a discriminatory impact upon a protected class should be judged in terms of its effect on the ability of that class to obtain the highest classification. In other words, if the highest classification on the Salient Factor Score (i.e., the "Very Good" rating, which results from nine to eleven point score) were to a material degree disproportionately White, this showing of adverse impact is not necessarily rebutted by demonstrating that the lowest classification is also disproportionately White. Second, even if the Salient Factor Score does not have a discriminatory impact on the prison population, it does not follow that it will not have a discriminatory impact on the quite different population that comes before the sentencing judge. In part because of the impact of plea bargaining (which favors the wealthier defendant who has retained experienced private counsel) and the lesser likelihood that middle-class defendants will receive a prison term, the racial breakdown of the population of offenders at this stage of the criminal process more closely resembles the general population than does the racial breakdown of the population of offenders who are actually imprisoned. In short, it seems a likely hypothesis that the population of offenders facing sentencing will experience much of the same discriminatory impact as does the general population when such racially sensitive criteria as level of education, arrest. records, and marital status are applied to it. 
But in that year, the United States Board of Parole adopted a "Guideline Table" for parole-release decisions that in essence amounts to the formalized use of a prediction table on a national scale. ${ }^{187}$ Under this guideline system, two classifications are made with respect to each offender: (1) the actual offense committed by the offender is ranked on an "Offense Severity" scale, ${ }^{188}$ and (2) the offender is classified into one of four "risk" groups, depending on the rating he receives on a "Salient Factor Score."189 As the following abbreviated diagram of the Guideline Table ${ }^{100}$ shows, each of these two scales represents an axis on a matrix that the Board of Parole uses to determine ${ }^{191}$ the range of months within which an inmate may be released on parole:

SALIENT FAGTOR SCORE

\begin{tabular}{|c|c|c|c|c|}
\hline $\begin{array}{l}\text { Offense } \\
\text { Severity } \\
\text { Rating }\end{array}$ & $\begin{array}{l}\text { Very } \\
\text { Good }\end{array}$ & Good & Fair & Poor \\
\hline Low & $\begin{array}{c}6-10 \\
\text { months }\end{array}$ & $\begin{array}{c}8-12 \\
\text { months }\end{array}$ & $\begin{array}{l}10-14 \\
\text { months }\end{array}$ & $\begin{array}{l}12-16 \\
\text { months }\end{array}$ \\
\hline Moderate & $\begin{array}{l}12-16 \\
\text { months }\end{array}$ & $\begin{array}{l}16-20 \\
\text { months }\end{array}$ & $\begin{array}{l}20-24 \\
\text { months }\end{array}$ & $\begin{array}{l}24-30 \\
\text { months }\end{array}$ \\
\hline Very High & $\begin{array}{l}26-36 \\
\text { months }\end{array}$ & $\begin{array}{l}36-45 \\
\text { months }\end{array}$ & $\begin{array}{l}45-55 \\
\text { months }\end{array}$ & $\begin{array}{l}55-65 \\
\text { months }\end{array}$ \\
\hline
\end{tabular}

Using this matrix, an offender who has committed a crime of "very high" severity may serve a term as short as 26 months or as long as 65 months, depending upon his Salient Factor Score. The Salient Factor Score is, in turn, determined by weighing nine preselected personal characteristics of the offender, including such racially sensitive but morally neutral factors as level of education, past employment history, and marital status. ${ }^{192}$ The impact of the Salient

187. A comprehensive discussion of the Board's Guideline Table and Salient Factor Score is contained in Project, supra note 58, at 822-33. The governing regulations are set out at 28 C.F.R. $\S \S 2.1-.57$ (1974).

188. 28 C.F.R. $\S 2.20$ (1974). There are six severity ratings ranging from "low" to "greatest."

189. See 28 G.F.R. $\$ 2.20$ (1974).

190. The full table is set out in 28 C.F.R. $\S 2.20$ (1974).

191. While the guidelines are not mandatory and a "clinical evaluation of risk may override" the indicated prognosis that the table yields, 28 C.F.R. $\S 2.20(\mathrm{e})$ (1974), recent Board of Parole statistics indicate that between 81 and 89 per cent of all parole release decisions were within the guideline ranges. Project, supra note 58, at 869 n.293.

192. The Salient Factor Score has eleven points. Any score above eight yields a "Very Good" parole prognosis rating; a score of six, seven or eight results in a "Good" rating. Scores of four or five are rated "Fair"; scores less than four indicate a "Poor" parole prognosis. One point is lost if the offender does not have the equivalent of a high school diploma; another point is forfeited if he has not had verified employment (or full-time school attendance) for at least six months during the past two years. 
Factor Score on persons who lack a middle-class background can be severe, even if they are first offenders. For example, an unmarried offender who lacks the equivalent of a high school diploma and does not have the requisite prior employment history has already lost three points and cannot obtain the most favorable "risk" category rating even if he has no prior arrest or conviction record.108 In contrast, an offender of middle-class background who has a history of prior convictions will lose only two points if he has never been incarcerated and at most four points if he has. ${ }^{104}$

Two facts quickly become evident upon even a brief examination of the Guideline Table: First, its aim is incapacitation, not rehabilitation, since it relies exclusively upon "static" factors that exist at the time of the offender's conviction and ignores such variables as progress toward rehabilitation while in prison; ${ }^{105}$ and, second, in seeking to rank offenders in terms of their marginal risk of recidivism, the Salient Factor Score relies at least as much on information relating to the social and economic status of the offender as on information relating to his prior misconduct.

This reliance upon morally neutral criteria in an area where human liberty is at stake underscores two earlier-noted issues: can the use of such criteria be justified if it selects a disproportionate number of minority group members, and to what extent is it justifiable to classify offenders on a basis other than their actual conduct?

With respect to the first of these questions, the proponents of predictive indexes can argue that sentencing inevitably involves the making of probabilistic determinations and that their techniques, having been scientifically validated, are demonstrably more accurate than any other procedures developed to date. Yet, in a system of

Other factors employed (single marital status, history of drug use, number of prior incarcerations and, in particular, young age at first commitment) are also disproportionately possessed by Blacks in comparison with Whites. See Project, supra note 58, at 877, n.329. The factors employed by the Salient Factor Score are enumerated at 28 C.F.R. § 2.20 (1974).

193. Such a defendant can receive at most 8 points and will therefore receive a "Good" rather than a "Very Good" classification. See 28 C.F.R. \$ 2.20 (1974). The difference for such an offender in the case of an offense of a "Very High" severity rating will be a delay of 10 months in the date of earliest parole eligibility (36 months as opposed to 26 months for a "Very Good" rating) and of nine months in the date of assured release on parole ( 45 months versus 36 ).

194. See 28 C.F.R. $\S 2.20$ (1974).

195. Variance from the indicated time ranges is authorized "for cases with good institutional adjustment and program progress." 28 C.F.R. § 2.20(b) (1974). On the other hand, since the Salient Factor Score is based on the assumption that progress toward rehabilitation cannot be realistically judged, it is uncertain to what extent this authority is actually used. 
justice that prides itself on the irrelevance of social, racial, or economic status, predictive efficiency is neither the sole nor the paramount consideration. Some safeguards are then needed to minimize the discriminatory impact of criteria that, unlike a prior conviction or other evidence of misconduct, do not possess independent moral authority. While the price paid for such safeguards may be the loss of some predictive efficiency (although, as will be discussed later, less restrictive alternatives to the use of racially sensitive criteria may be available), the ugly alternative is a form of individualization increasingly based on status rather than on conduct.

This then raises the second and more troublesome issue: Even apart from the discriminatory impact of such criteria, should there not be some limit placed on the ability of the state to classify offenders on the basis of factors relating to status rather than to conduct? ${ }^{198}$ Carried to the extreme, this emphasis on status would

196. It is, of course, possible to argue that constitutional prohibitions on the punishment of "status" exist. See Robinson v. California, 370 U.S. 660 (1962). Such cases, however, seem concerned with (and thus only provide a remedy for) individuals, such as drug addicts or vagrants,' who fall into certain disfavored social categories. To challenge the more generalized use of neutral socioeconomic criteria, at least where the use of such criteria does not produce a racially discriminatory impact, it seems necessary to find a principle of greater utility than that afforded by Robinson and its progeny. One alternative might be the use of what has been termed the "personal guilt" doctrine. In Scales v. United States, 367 U.S. 203 (1961), the Supreme Court first enunciated the idea that punishment must be based on "personal guilt": "In our jurisprudence guilt is personal, and when the imposition of punishment on a status or on conduct can only be justified by reference to the relationship of that status or conduct to other concededly criminal activity ...., that relationship must be sufficiently substantial to satisfy the concept of personal guilt in order to withstand attack under the Due Process Clause of the Fifth Amendment." 367 U.S. at 224-25 (emphasis added). See also Weber v. Aetna Cas. \& Sur. Co., 406 U.S. 164, 174 (1972); Levy v. Louisiana, 391 U.S. 68 (1968); St. Ann v. Palisi, 495 F.2d 423, 425-26 (5th Cir. 1974).

Concededly, the "personal guilt" requirement is a principle of substantive criminal law and not of the law of corrections. According to traditional doctrine, the issue at sentencing is not whether the individual is to be punished, but to what extent, and, in answer to this latter question, it is permissible to consider factors relating solely to his status in so far as they offer a probabilistic guide to his future behavior. In short, the requisite relationship between punishment and personal guilt can be said to exist by virtue of his criminal conviction. Yet is this relationship between punishment and personal guilt "sufficiently substantial" (in the Scales terminology) if the actual length of sentence depends more on the offender's status than on the criminal act for which he was convicted? Viewed in this light, the approach of the Fifth Circuit in St. Ann seems particularly interesting. Starting with the premise that "punishment must be founded on an individual's act or omission, not his status, political affiliation or domestic relationship," 495 F.2d at 425 , the Fifth Circuit then utilized the less drastic means doctrine to consider whether a compelling governmental interest existed (because of the lack of reasonable alternatives) to justify an "inroad upon the theory of personal guilt." 495 F.2d at 428 . By analogy, this same form of analysis could be used in situations in which the relationship between the actual crime and the sentence imposed seemed insubstantial. For an examination of the manner in which a court could inquire if reasonable alternatives to classification based on status existed, see text at notes $341-48$ infra. 
not only abandon the individualized-treatment model's preoccupation with rehabilitation, but would also reject any consideration of the proportionality of the offense committed by the offender (in terms of its severity) to the length of his incarceration. ${ }^{107}$ Thus, in a jurisdiction employing an extreme indeterminate sentencing structure (such as the one-year-to-life sentence frequently assigned in California), a reliance on factors relating primarily to status rather than conduct could create (in the absence of a principle of proportionality) a system of almost Calvinistic predestination in which the offender would be classified as either among the "elect" or the "damned." 198 If one acknowledges that there is something fundamentally unfair about one offender serving a twenty-year sentence for a crime for which another offender serves only three years (where each offender is similarly situated, except for factors relating exclusively to their respective social and economic status), then one is forced to concede that some balance must be struck between efficiency and fairness that may result in denying the state the right to classify the

197. Recent commentators on the philosophy of punishment have generally agreed that punishment that is imposed in order to incapacitate the offender cannot be justifiably increased on the basis of predicted dangerousness beyond, in Norval Morris' phrase, the maximum "deserved by the last crime or series of crimes for which the offender is being sentenced." This limitation Morris terms the "principle of desert." N. Morris, The Future of IMprisonMent 73-77 (1974). Both Morris and the American Friends Service Committee, which wrote Struggle for Justice, are in agreement that offenders will, understandably, be unable to accept sentencing disparities based on the offender's "similarity to an imprecisely defined group of people, some of whom seem to have behaved in a like manner in the past." N. Morrus, supra, at 35. Here, however, they part company: Morris uses the principle of desert only to establish a maximum on the imposition of punishment and would thus apparently permit the consideration of categoric-risk factors to justify clemency; the authors of Struggle for Justice insist upon mandatory fixed sentences. Compare id. at 75 with STRUGGLE FOR JUSTICE, supra note 2 , at 144,148 . Without endorsing the rigidity in. herent in the position of the American Friends Service Committee, I believe that Professor Morris" confidence in the "principle of desert" to establish a satisfactory maximum boundary may be misplaced, since there is still relatively little evidence (with the notable exception of the state of California) that sentencing judges have accepted a principle of proportionality between the severity of the crime and the length of the punishment. Thus, this article proposes that fairness requires that the classification of offenders within the maxima and minima suggested by Professor Morris be accomplished primarily by reference to the actual conduct, rather than the status of the offender. Admittedly, the distinction between conduct and status blurs at the margins, but it possesses a fundamental and perceivable equity, which the offender can understand and accept. Such an emphasis on conduct also seems compelled by the limited predictive powers that prediction tables and similar screening devices have exhibited to date. See F. SIMoN, supra note 179; Diamond, supra note 16.

198. The Board of Parole's Guideline Table is not subject to this criticism, however, since the result of balancing the Salient Factor Score against an Offense Severity rating is to incorporate the concept of proportionality between the offense and the sentence into the Table. The California base-expectancy table, discussed in the text at note 180 supra, however, does not appear to have explicitly recognized such a limitation on categoric-risk sentencing. 
offender on the basis of the most accurate system available to it. So long as any predictive system yields a material number of false positives, the concept of fairness should not be equated with that of predictive efficiency (the goal of reducing to the minimum possible the total number of false positives), since the concept of fairness seems necessarily broader in that it requires that we look beyond the total number of false positives and consider the relationship between those offenders who are selected to receive incremental punishment for a given crime and those who are not. ${ }^{199}$

Assuming then that efficiency must to some degree be sacrificed to fairness, what is the watershed between a "fair" and an "unfair" prediction system? Perhaps the answer lies in the fundamental premise that the criminal law is ultimately dependent upon concepts of personal responsibility. ${ }^{200}$ It is exactly such concepts that are

199. To illustrate, assume two prediction tables, one of which is 75 per cent efficient (meaning that 25 per cent of those it identifies as recidivists are false positives) and operates virtually exclusively on the basis of socioeconomic information about offenders, and the other of which is only 65 per cent efficient but operates principally on the basis of factors relating to prior misbehavior of the offenders. Assume further that the first table will treat many youthful first offenders more severely than multiple offenders because their youth makes them statistically more likely to commit further crimes. In contrast, the second table will generate a higher number of false positives, but, proportionally, more of these false positives will be individuals who share a lesser entitlement to clemency because of their prior transgressions. Although this example may seem extreme, its point is that the concepts of fairness and predictive efficiency can point in divergent directions.

An appropriate balancing of the competing principles of fairness and accuracy cannot be accomplished in the abstract, but two considerations seem to stand out: First, what level of accuracy is obtainable? Even though prediction devices may be relatively more accurate than intuitive decision-making, they may still be highly inaccurate in an absolute sense. Thus, the role to be accorded concepts of fairness as a constraint upon the use of such devices should depend on the absolute level of predictive efficiency obtainable. For example, if a prediction table could be shown to be 95 per cent effective, the concept of fairness among offenders might deserve only a modest role. Conversely, if prediction tables are able to achieve only a 40 per cent correlation between actual and predicted results (which may be their present level of efficiency, see note 179 supra), then concepts such as equality and relative blameworthiness deserve a much greater role, since otherwise we are faced with the worst possible combination: a prediction system that is both "unfair" and inaccurate.

Second, what cost is incurred in terms of loss of predictive efficiency by recognizing a principle of fairness? Assuming that the trade-offs between efficiency and fairness can be quantified, it seems likely that most would agree that, in the example given above, since the loss of predictive efficiency is slight, the less efficient table, which does not prejudice the young first offender, is preferable.

While questions involving the appropriate trade-offs between fairness and accuracy may on occasion present seemingly intractable problems, the considerations outlined above could at least be weighted and evaluated by appellate courts on a class action basis without the expenditure of judicial time that a case-by-case review of individual sentencing determinations would require.

200. For a modern reaffirmation of the role of personal responsibility in the jurisprudence of the criminal law and, in particular, its importance in the assignment of punishment, see H. HART, PUnISHMENT AND RESPONSIBICITY ch. VII et passim (1968). Basically, Professor Hart maintains that whatever the underlying purpose of punish- 
ignored by categoric risk prediction systems that focus not on the likelihood of recidivism by the individual in question, but on the base-expectancy rate for the various groups to which he belongs. The distinction between predictions based on past conduct of the individual and predictions based on his group status is premised on the root concept that punishment must be proportional to what the individual has actually done. ${ }^{201}$ To abandon this distinction is to stray perilously far from the moral foundation of personal responsibility that underlies the criminal law. To summarize: Sentencing does involve the making of probabilistic determinations, but to the degree that the basis for assessment depends not on what the individual has done, but rather on what others allegedly similarly situated have done, the offender can legitimately complain that the punishment imposed is unfair.

Serious methodological problems also surround the use of prediction tables. ${ }^{202}$ For example, it is never certain that the factors

ment (e.g., whether a deterrent theory or a retributive theory is employed) the concept of personal responsibility remains important and should inhibit us from treating men as "alterable, predictable, curable or manipulatable things." Id. at 183. While his arguments cannot possibly be summarized in this article, it is worth noting that Professor Hart suggests that the requirement that "like cases be treated alike" is "infringed ... when the ground for different punishment for those guilty of the same crime is neither some personal characteristic of the offender connected with the commission of the crime nor the effect of punishment on him." Id. at 24. It is difficult to see how, for example, the offender's status as an unmarried person, which is considered by the Salient Factor Score, would satisfy either of these preconditions for variation of punishment.

201. Norval Morris has recently suggested that not only is prediction based exclusively on the individual's prior conduct (an "anamnestic" prediction in his phrase. ology) the only fair method of classification for parole selection, but it is increasingly becoming the most precise and efficient method of prediction. See N. Morris, supra note 196 , at $31-34$.

202. The various methodological issues concerning the use of particular prediction tables are beyond the scope of this article. Suffice it to say, however, that considerable debate has been engendered over such issues as whether prediction tables have cross-cultural validity, whether they become stale over time so that an undetected "shrinkage" in predictive power occurs, and whether, in particular, subjective criteria that involve the use of judgment (such as the attitude of the offender) can legitimately be built into such tables. See Laulicht, Problems of Statistical Research: Recidivism and Its Correlates, 54 J. CrRM. L.C. \& P.S. 163 (1963). One system using such subjective criteria is the juvenile court "behavior profile index rating," discussed in note 185 supra. A child who claims to be blameless receives five adverse "points," while a youth deemed "remorseful" receives but one. Stern, supra note 180 , at 226 . The extent to which a probation officer is able to judge "attitude" in a manner consistent with that of his fellow officers is open to considerable doubt. See Prigmore, An Analysis of Rater Reliability on the Glueck Scale for the Prediction of Juvenile Delinquency, 54 J. Crum. L.C. \& P.S. 30 (1963). The culmination of the trend exemplified by the prediction table would be the automation of the process of deciding what form of "treatment" to prescribe for a given diagnosis. Already, some computerized applications of the prediction table approach have been put into use so as to produce not only a statistically based "diagnosis," but also a suggested form of treatment. See Vondracek, Urban \& Parsonage, supra note 180, at 94-97. 
isolated by the statistician as bearing a positive correlation with recidivism are as narrowly limited as possible. More discriminating criteria may exist. ${ }^{203}$ Another problem is that, despite their seemingly automatic precision, prediction tables are subject to manipulation by administrative personnel and can cloak highly discretionary decisions. ${ }^{204}$ Finally, the ranking of offenders in different risk categories according to slight numerical differences in their scores can be misleading. No attributes have yet been discovered that sharply differentiate outcome groups; distinctions can be made only in terms of marginal probabilities. For example, the earlier noted California base expectancy table yields a bottom seventeen per cent, of which only forty-six per cent will fail on parole within the prescribed time period. $^{205}$ Characterizing any offender as being at the bottom of this scale is thus misleading since the actual probability is that he will not fail on parole. Arguably, a minimal prerequisite for use of such a table is that it yield outcome groups having significantly different probabilities of success or failure.

In summary, the categoric risk technique has certain virtues: it encourages uniformity of treatment, simplifies data-handling, and outperforms clinical techniques. But, notwithstanding its increasing acceptance, a legal framework has not yet been created in which the competing considerations of fairness and efficiency can be balanced.

\section{The Clinical Prediction Procedure}

Those criminologists who favor clinical classification methods

203. Cf. Dershowitz, supra note 162, at 816. For example, suppose a false positive factor (such as, hypothetically, a period of four or more months unemployment during the year preceding arrest) showed a 60 per cent correlation with failure on parole within two years. Conceivably, 75 per cent of the persons sharing this false positive factor might also share an undetected true positive factor (again, hypothetically, they are hard drug users). Thus, out of a sample group of 100 offenders (all sharing the false positive factor), 75 would be hard drug users and 25 would not. If 60 out of these 75 fail on parole, it would be possible to conclude that all persons sharing the false positive factor faced a 60 per cent risk of failure.

204. See, e.g., Project, supra note 58, at 837-38 (describing an instance in which administrative personnel manipulated the Salient Factor Score by ignoring an offender's juvenile convictions).

205. McGee, supra note 37, at 195. See also Schuessler, supra note 163, at 603 . Of those rated only "Fair" by the Salient Factor Score, 60.8 per cent are expected to succeed on parole. "Good" risks were found to have a 77.4 per cent chance of success. Project, supra note 58, at 875 . Such percentages are, however, somewhat misleading. As the British Home Office study concluded, "simple criteria like reconviction or parole violation are very inadequate measures of a person's criminality. To define 'success' and 'failure' as the absence or presence of reconviction is to distort a complex situation and treat cases which are not extreme risks as though they were; chances of accurately predicting the real risks are thus prejudiced." F. SrMoN, supra note 179, at 157. Use of such an "over-simplified criterion," it added, is "to dichotomize what is really a continuous scale." Id. 
have criticized the statistical prediction approach for its failure to provide any etiological explanation of why or how an individual becomes a recidivist. Without such an explanation, the clinician has argued, rehabilitation is unlikely since the individual offender's pathology has not been diagnosed. Accordingly, clinical approaches have begun by developing theories to explain the underlying psychological abnormalities that cause an individual to commit crimes, and have then proceeded by constructing over-all typologies of offenders within which the individual offender may be classified.208

Recent years have witnessed a steady proliferation of typologies, each favored by a different school of clinicians. ${ }^{207}$ Nevertheless, there exists compelling evidence that among all the means of differentiating offenders, clinical prediction is the least satisfactory. Three reasons for this are chiefly cited by critics: First, in comparative tests, clinical methods have never been able to match the predictive efficiency of statistical prediction tables; ${ }^{203}$ second, the assumption that underlies most typologies-that the offender is psychologically abnormal, or at least significantly different from the average citizen ${ }^{200}$ -

206. See generally Toch, The Care and Feeding of Typologies and Labels, FED. Probation, Sept. 1970, at 15. See also note 219 infra.

207. TASK ForCe REPORT: CoRRECTIONs, supra note 2, at 20. The Task Force made an attempt to set forth and develop a consensus typology. See id.

Probably the best known clinical classification scheme is that developed by Eleanor and Sheldon Glueck as a result of their studies of delinquent boys in Massachusetts. From these studies, extending over several decades, they constructed the Glueck Social Prediction Index, which emphasizes such highly subjective factors as "cohesiveness of the family," "affection of the father for boy," and "supervision of boy by mother" in order to determine the risk of recidivism. See S. GruEcK \& E. Gluzck, supra note 15. Although the Gluecks also attempt to develop statistical rclationships, their technique exemplifies the principal problem with any clinical classification system: its criteria are generally far more vague than those employed by the statistician so that different clinicians employing the Glueck system might give different ratings to the same individual. See Prigmore, supra note 202, at 40. See also Voss, The Predictive Efficiency of the Glueck Social Prediction Table, 54 J. CrIM. L.C. \& P.S. 421 (1963).

208. In an often-cited work, Paul Meehl, a psychologist, reviewed some 27 empirical studies that contrasted the predictive success of clinical and statistical methods; in 17 of those studies, statistical methods were found to be significantly superior; in no study did a clinical approach outperform a statistical technique. P. MEEHL, Cuinical Versus Statistical Prediction (1954). A more complete survey in 1966 produced the same results: out of 40 comparisons made, the clinical mode was never able to outperform the statistical. Dershowitz, supra note 162, at 819. See also Meehl, supra note 125.

209. Morris, supra note 73 , at 194. In opposition to the psychiatric view that recidivism is largely the product of an innate personality disorder, sociologists have in increasing numbers adopted "situational" interpretations, arguing that fully "normal" individuals who find themselves frustrated by such societal obstacles as poverty or racism may rationally adopt illegitimate means of attaining their goals. See $R$. Cloward \& L. OHLIN, DeLINQuency and Opportunity 145-49 (1961). Under the theory of differential opportunity, espoused by Cloward and Ohlin, the delinquent youth is apt to be not the weakest, most dependent member of the group, but a perceptive, adaptable leader. Cf. Chase, supra note 8, at 688-89. 
is subject to substantial dispute; ${ }^{210}$ and, finally, clinical tests have shown a marked tendency to overpredict, that is, to classify too high a percentage of individuals as dangerous. ${ }^{211}$

Illustrative of the tendency toward overprediction is the experience of The Patuxent Institution for Defective Delinquents, a model Maryland prison for "nonpsychotic" inmates administered along the lines of a mental hospital. Under Maryland's Defective Delinquent statute,,$^{212}$ an offender who is legally sane may be referred to Patuxent for psychiatric evaluation and, if diagnosed a "defective delinquent," may be committed for an indeterminate period until deemed cured by Patuxent's Board of Review (a majority of which is composed of psychiatrists and related medical personnel). Statistically, 85 per cent of those referred for psychiatric evaluation have been diagnosed as defective delinquents. ${ }^{213}$ Furthermore, one survey has revealed that 38 per cent of all Patuxent inmates were being held beyond the terms of their original criminal sentence. ${ }^{214}$ In the 18 years that it has operated, only 115 out of a total of 985 inmates committed to Patuxent have been released as cured.215

210. Dr. Howard Rome, Professor of Psychiatry at the Mayo Graduate School, has criticized the "folk-belief . . . that all unlawful violent behavior is a direct product of mental disease." Rome, supra note 128, at 189. No "simple test for the presence of so-called abnormal characteristics" is adequate, he states, for the same reason that makes the use of prediction tables so problematic: whatever the variable identified as having influenced the life-histories of persistent offenders, there will be a sizable number of nonoffenders who share the same characteristics. Id. at 188.

211. Surveying the literature of clinical attempts at prediction, Professor Dershowitz has concluded:

$[P]$ sychiatrists are rather inaccurate predictors; inaccurate in an absolute sense, and even less accurate when compared with other professionals, such as psychologists, social workers and correctional officials; and when compared to actuarial devices, such as prediction or experience tables. Even more significant for legal purposes, it seems that psychiatrists are particularly prone to one type of erroroverprediction. . . . Indeed, our research suggests that for every correct psychiatric prediction of violence, there are numerous erroneous predictions.

Dershowitz, supra note 16, at 377. The Glueck Social Prediction Table in particular has been criticized for its tendency to overpredict. See Prigmore, supra note 202, at 191. See generally Diamond, supra note 16.

212. MD. ANN. CoDE art. 31B, §§ 5-9 (1957).

213. Stanford, supra note 8 , at 71.

214. Id. at 78. Seventy-five per cent of those sentenced to original terms of five years or less have been held beyond what would otherwise have been the expiration date of their sentence. $I d$.

215. Id. at 80. Another 332 have won release against the recommendations of the psychiatric staff through recommitment hearings. Id. Approximately 22 per cent of Patuxent's inmates have been committed for crimes not involving any act of violence. Id. at 72. Although there has been a remarkably low rate of recidivism among those released on the recommendation of the psychiatric staff, one commentator has observed that "Patuxent apparently achieved this happy result by releasing almost no one." Burt, Of Mad Dogs and Scientists: The Perils of the "Criminal-Insane," 123 U. PA. L. REv. 258, 287 (1974).

Another example of psychiatric overprediction is chronicled in two studies of the 
The Patuxent experience indicates an attitude far more cautious than even the most conservative of parole boards. Although the broad definition of "illness" employed by many forensic psychiatrists is at least partially responsible for this, ${ }^{210}$ the tendency toward overprediction seems to have a more fundamental source. The vastly different outlooks of the medical and legal professions appear to be at the crux of the problem: To a physician seeking to diagnose a disease, the possibility of overprediction (that is, treating for a disease not present) may seem more desirable than the danger of not responding to possible symptoms of the disease. In contrast, lawyers (and, to a lesser degree, probation officers and social scientists) recognize that their task involves a delicate balancing of individual rights against the self-protective needs of the state. In short, the physician's orientation is to search for illness while the lawyer prides himself on his ability to be able to evaluate impartially the competing claims in any dispute. Because the psychiatrist tends to focus only on the benefits of treatment to the "patient," use of the medical analogy leads to the downgrading of the individual's own preference for liberty. ${ }^{217}$

To date, there has been general dissatisfaction with most attempts to construct a standardized clinical typology of offenders. ${ }^{218}$ Despite growing doubts as to their reliability, some states have utilized such typologies as a screening device in the parole release decision. ${ }^{210}$

aftermath of Baxstrom v. Herold, 383 U.S. 107 (1966): Steadman \& Halfon, The Baxstrom Patients: Backgrounds and Outcomes, 3 SEMINARs IN PsYchIATRY 376 (1971); Steadman \& Keveles, The Community Adjustment and Criminal Activity of the Bax. strom Patients 1966-1970, 129 AM. J. Psychiatry 304 (1972). But see Allen, Book Review, 73 MrCh. L. REv. 1517, 1525-27 (1975).

216. See Lanham, supra note 134, at 309.

217. See Note, Police Initiated Emergency Psychiatric Detention in Michigan, $5 \mathrm{U}$. MICH. J. L. REF. 581, 589 (1972).

218. The President's Commission concluded that most such attempts failed "to view data in a sufficiently complex fashion and to classify subjects" in a manner that was "relevant" to treatment. TASR FORCE REPORT: CORRECTIONS, supra note 2, at 22. Cf. S. Rubin, Psychiatry and Criminal Law 105-06 (1965).

219. Since 1961, the California Youth Agency has made increasingly extensive use of a clinical typology in determining when to release or grant limited probation status to juveniles assigned by California courts to its custody. The typology postulates seven states of personality integration and operates on the premise that juvenile crime is the result of arrested development at one of the earlier of these stages. In part because of its considerable complexity, the typology initially received substantial attention and acclaim. See, e.g., TASK FORCE REPORT: CORRECTIONS, supra note 2, at 22. However, a study by a team of social scientists suggests that the vagueness of the classifications, the absence of explicit behavioral criteria, and the methodological laxness in the rating of individual offenders rendered the California typology a highly dubious basis upon which to justify treating individual offenders differently. See Beker \& Heyman, $A$ Critical Appraisal of the California Differential Treatment Typology of Adolescent offenders, 10 Grmanology 3 (1972). 
Practical experience with these classification systems has led to charges that their convoluted categories are often manipulated by the clinician to buttress what in reality are merely intuitive judgments. ${ }^{220}$ When this occurs, the damage is not that intuitive judgments are made, for these are frequently inevitable, but that a misleading aura of certainty has been created by the clinician in order to defend his position as the indispensable expert. ${ }^{221}$

In summary, neither the dominant approach to the presentation of sentencing information (the case attribute method) nor current alternatives (the statistical and clinical approaches) present acceptable models for the sentencing process. To the extent that the dependence of the categoric risk approach upon racially sensitive factors can be reduced, and the role of status-dependent criteria minimized without commensurate loss of predictive efficiency, the categoric risk approach unquestionably represents the most preferable alternative. It alone is capable of ensuring consistency of performance. Indeed, short of its outright adoption, it may still offer an effective means to facilitate appellate review. Even if exising prediction tables have too discriminatory an impact to be used properly in the initial sentencing determination, they could still serve as a means of filtering out cases in which unjustifiably severe sentences have been assigned. For example, if a given sentence exceeded the average sentence assigned for a particular offense, the appellate court could utilize such a table to consider whether the offender posed a greater-than-average risk of recidivism. If he did not, the burden would then fall on the lower court to explain what factors made the particular sentence appropriate. $^{222}$ Before discussing possible reforms, however, it is first necessary to examine some of the recent trends in the case law of sentencing.

220. See, e.g., Beker \& Heyman, supra note 219, at 21.

221. See Dershowitz, supra note 16, at 371. Dershowitz's view is that clinicians have frequently and deliberately pre-empted the court's role on the assumption that they alone are competent to deal with questions involving an individual's state of mind.

222. Such a compromise would provide a means for filtering out frivolous appeals and would limit the number of sentencing cases that appellate courts would have to consider. This does not mean, however, that the sentencing judge should be required to explain his sentence only in the exceptional case. Ideally, findings of fact should be required in every sentencing determination as in every nonjury trial.

Undeniably, the use at the appellate stage of prediction tables that employ racially sensitive variables may be seen by minority group members as unfair, since it merely delays the moment at which a biased filtering device is employed. But the advantage of such a two-step procedure is that the primary sentencing determination would be conducted in what was, at least on the surface, a racially neutral manner, and some defendants would be provided with a means of obtaining sentence reductions. Such tables might also be utilized on appeal by an individual who has received the average sentence for the crime in question but who could show that he posed little or no 


\section{Developments in the Case Law}

An almost schizophrenic quality has characterized the development of the constitutional law of sentencing over the past quarter century. Two separate and seemingly contradictory lines of cases are discernible, each traceable to one of two historic decisions handed down in rapid succession by the same bench of the Supreme Court in the late 1940's. First, in Townsend v. Burke, ${ }^{228}$ the Court ruled that due process is violated when a defendant is sentenced on the basis of material misinformation. Then, in the following year, the Court was faced in Williams $v$. New York ${ }^{224}$ with a sentence of capital punishment explicitly based on allegations in a pre-sentence report that were only partially disclosed to defense counsel. ${ }^{225}$ Declining to extend the Townsend precedent, the Court rejected the due process challenge, which it saw as leading to the imposition of trial-type standards at sentencing. ${ }^{226}$

The scope of the Court's holding in Williams has long been debated: Did it hold only that hearsay evidence might be received at sentencing, or did it deny the defendant any constitutional right to

risk of recidivism under such tables. The suggestion made in the text that such a procedure be followed by the appellate court only when the sentence exceeds the average length for the crime is intended to prevent the appellate decision from simply replacing the primary sentencing determination with the results dictated by the pre. diction table.

223. 334 U.S. 736 (1948). In Townsend, the sentencing judge had apparently misread the section of the pre-sentence report dealing with the defendant's prior criminal record and, reading his error into the record, confused arrest records with prior con. victions. See 334 U.S. at 739-40.

For a comprehensive discussion of the defendant's procedural rights at sentencing (which the following analysis does not purport to provide), see Pugh \& Carver, Due Process and Sentencing: From Mapp to Mepa to McGautha, 49 Texas L. Rev. 25 (1970).

224. 337 U.S. 241 (1949).

225. Despite the jury's recommendation of a sentence of life imprisonment, the trial judge imposed the death sentence. 337 U.S. at 242. This decision was based on a lengthy pre-sentence report that stated that the defendant was sexually maladjusted and had been the perpetrator of a series of other unsolved violent crimes. While the report itself was never disclosed to defense counsel (nor was disclosure requested), the judge alluded at sentencing to its principal contents by stating that he "had information" that the defendant had been "identified" and had "confessed" to a series of other crimes. See 337 U.S. at 244.

On appeal to the Supreme Court, defense counsel relied on the confrontation clause of the sixth amendment to assert that hearsay evidence could not be received at sentencing. Speaking for the Court, Justice Black responded that such hearsay information was necessary if the "modern penological policy" of individualized scntences geared to the rehabilitative needs of the offender were to be attained. 337 U.S. at 249-50. An insistence on trial-type standards for the receipt of information at sentencing, he argued, would prove more injurious than beneficial to most defendants, since it would also foreclose the receipt of redeeming information.

226. 337 U.S. at 246-47. 
inspect or challenge the information used at sentencing:227 Because of the sweeping language in the majority opinion emphasizing the importance of "individualized" sentences and the role of the presentence report in fashioning such sentences, the dominant tendency has been to cite Williams for the broad proposition that disclosure of the pre-sentence report is not compelled by the fourteenth amendment, since it might disrupt the "rehabilitative purposes" of the sentencing process. ${ }^{228}$ The practical consequence of this interpretation of Williams has been to place the convicted defendant in the anomalous situation of having a right without a remedy: entitled by Townsend to a sentencing decision free from misplaced reliance on inaccuracies in the pre-sentence report, yet denied access to that report by the prevailing gloss placed upon Witliams. From time to time, if a sentencing judge revealed his confusion on the record and clearly relied on incorrect information, an appellate court would rediscover the latent principle of Townsend and require a resentencing. ${ }^{228}$ The judge who sentenced in silence, however, seldom met reversal on appeal in the federal courts.

After Williams, the law of sentencing remained strangely static in contrast with the rapid pace of constitutional developments in other areas of the criminal law. ${ }^{280}$ By the 1970's, however, the

227. Because disclosure of the pre-sentence report was never actually requested by defense counsel in Williams, some cases and the majority of the commentators have taken the view that the Williams holding was necessarily limited to the question whether pre-sentence reports containing hearsay could be used at all. So construed, Williams would deal with only the use, not the disclosure, of such reports and would hold only that hearsay evidence might be received. Williams then would otherwise be silent on the question of what procedural rights were available to defendants who, unlike defendant Williams, sought to challenge the accuracy of the pre-sentence report. See Baker v. United States, 388 F.2d 931 (4th Cir. 1968); Cohen, supra note 2 (summarizing the viewpoints of recent commentators). Cf. Marano v. United States, 374 F.2d 583, 585 n.3 (1st Cir. 1967).

228. See, e.g., United States v. Lloyd, 425 F.2d 711 (5th Gir. 1970); United States v. Gross, 416 F.2d 1205 (8th Cir. 1969), cert. denied, 397 U.S. 1013 (1970); Cook v. Willingham, 400 F.2d 885 (10th Cir. 1968); Powers v. United States, 325 F.2d 666 (1st Cir. 1963). A second, more restrictive interpretation of Williams is that the sentencing judge is not required to conduct a hearing or permit cross-examination. In Specht v. Patterson, 386 U.S. 605 (1967), the Court, in an opinion by Justice Douglas, a consistent champion of disclosure, read Williams to hold "that the Due Process Clause of the Fourteenth Amendment did not require a judge to have hearings and to give a convicted person an opportunity to participate in those hearings . ..." 386 U.S. at 606. Since Justice Douglas has repeatedly urged amendment of the Federal Rules of Criminal Procedure to require disclosure, his position in Specht seems best interpreted as rejecting a constitutional requirement of trial-type hearings. Such a position would be consistent with such cases as Morrissey v. Brewer, 408 U.S. 471 (1972), and Goldberg v. Kelly, 397 U.S. 254 (1970), which hold that informal hearings will satisfy due process requirements.

229. See United States v. Malcolm, 432 F.2d 809 (2d Cir. 1970).

230. Some important precedents were, however, established. During the 1960's, the Court decided that the provision of counsel was constitutionally required at sentencing, 
justification of "rehabilitative purpose" had lost much of its persua" sive power: In Morrissey v. Brewer, ${ }^{231}$ Gagnon v. Scarpelli, ${ }^{232}$ and Wolff $v . M c D o n n e l l,{ }^{233}$ the Court wrote a detailed code of procedures to govern parole and probation revocation proceedings and prison disciplinary hearings, despite the claim that such procedures would interfere with the rehabilitative functions of the parole board and prison authorities. Potentially even more destructive of the traditional immunity of these authorities from judicial review are recent decisions of three circuit courts holding that a parole board is constitutionally required to supply a written explanation, sufficiently specific to permit appellate review, of the reasons for its refusal to grant parole..$^{284}$

reasoning that sentencing was a "critical stage" of a criminal prosecution. Mempa v. Rhay, 389 U.S. 128 (1967); McConnell v. Rhay, 393 U.S. 2 (1968), (applying Mempa retroactively). In addition, in a decision with potentially enormous ramifications, the Court held in Kent v. United States, 383 U.S. 541 (1966), that in juvenile-court waiver hearings, counsel must be permitted to examine the pre-sentence report and be given an opportunity to rebut all "materials which are susceptible to challenge or impeachment." 383 U.S, at 563 . While Kent did not discuss the procedural means counsel might employ, it emphasized that is was "precisely the role of counsel to 'denigrate' [the probation report]," and added that "[t]here is no irrebutable presumption of accuracy attached to staff reports." 383 U.S. at 563. Certain "ex parte analyses" from the probation staff were excluded from this rule of mandatory disclosure, subject to the requirement that "secret information" could not be relied upon. The significance of Kent is limited, however, by the uncertain degree to which it is based on statutory grounds. See Coffee, supra note 30 , at 600 . Still, Kent was cited with approval in In re Gault, 387 U.S. 1 (1967), which was expressly based on constitutional grounds.

Both Kent and Mempa (which dealt with a combined sentencing and probation revocation hearing) are typical of other sentencing cases of the 1960's, in that the Court was prepared to establish clear procedural standards only after it had first distinguished the case before it from the typical sentencing situation. See Baxstrom v. Herold, 383 U.S. 107 (1966); North Carolina v. Pearce, 395 U.S. 711 (1969).

231. 408 U.S. 471 (1972).

232. 411 U.S. 778 (1973). In Gagnon, the Court also indicated that counsel must be appointed at parole revocation proceedings where there are "substantial reasons which justified or mitigated" the parole violation. 411 U.S. at 790. This function of mitigating admitted violations places the attorney in a role that is inconsistent with the "reha. bilitative model" of the dispositional process, for it recognizes that the dispositional decision maker needs the assistance of the attorney in organizing and presenting dispositional data. In short, the Gagnon case implies (as did Kent) that the attorney's role is not limited to disproving the fact of a violation, but extends to the process by which the decision maker evaluates the character of the offender.

239. 418 U.S. 539 (1974). The due process requirements established by Wolff for prison disciplinary hearings at which "good time" credit could be lost were minimal (basically consisting of notice and a hearing), but show the Court to be unwilling to view prison administrators as functioning benevolently in the "best interests" of the inmates. In sum, the decision appears to represent at least the partial abandonment by the Court of the "rehabilitative model" as applied to issues of prison administration.

234. See Childs v. United States Bd. of Parole, 511 F.2d 1270 (D.C. Cir. 1974); Bradford v. Weinstein, 519 F.2d 728 (4th Cir. 1974), cert. granted, 43 U.S.L.W. 3636 (U.S. June 2, 1975) (No. 74-1287); United States ex rel. Johnson v. Chairman of N.Y. Bd. of Parole, 500 F.2d 925 (2d Cir.), vacated as moot sub nom. Regan v. Johnson, 419 
The result of these innovations in the law of probation and parole has been to make the absence of similar procedural protections at the sentencing stage appear to be an increasingly isolated anomaly. Moreover, as we shall next see, it is an anomaly that shows growing signs of decay. Although for the moment the rule of nonreview still remains largely intact, a series of lower court cases has established specific procedural protections that can no longer be reconciled with the traditional immunity of the sentencing judge. In the selective tour that follows, we shall seek chiefly to measure the latent potential for change that exists in recent case law against the earlier outlined critique of the sentencing process.

\section{A. Procedural Reform}

\section{The Trend Toward Disclosure}

Using a variety of techniques, a number of appellate courts have begun to require disclosure of at least some portion of the presentence report. The most frequently utilized method has been to require partial disclosure or at least summarization by the sentencing judge of those portions of the pre-sentence report dealing with allegations of prior criminal conduct. Some courts have required disclosure only of conviction records, ${ }^{235}$ while others have ordered that all references to prior criminal activity be disclosed.286 Another approach has been to place on the sentencing judge the burden of justifying nondisclosure. ${ }^{237}$

Those courts requiring only partial disclosure have, however, restricted the Townsend holding in an important respect. Neither Townsend nor the most significant of its progeny, United States $v$.

U.S. 1015 (1974); Cooley v. Sigler, 381 F. Supp. 441 (D. Minn. 1974). These cases are discussed in the text at notes 304-10 infra. With the decision of the Supreme Court to review Bradford, a final resolution of this issue appears imminent.

235. See, e.g., United States v. Janiec, 464 F.2d 126 (3d Cir. 1972).

236. See, e.g., United States v. Picard, 464 F.2d 215 (1st Cir. 1972); United States v. Baker, 388 F.2d 931 (4th Cir. 1968). Cf. United States v. Solomon, 422 F.2d 1110, 1121 (7th Cir.), cert. denied, 399 U.S. 911 (1970). A troublesome question is whether summarization of the report is sufficient. Compare United States v. Carden, 429 F.2d 1126 (8th Cir. 1970), with United States v. Picard, 464 F.2d 215 (Ist Cir. 1972). Picard required full disclosure to the defendant himself as well as to defense counsel on the theory that only the defendant would know whether there existed information to rebut or mitigate the information contained in the pre-sentence report.

237. See United States v. Bryant, 442 F.2d 775 (D.C. Cir.), cert. denied, 402 U.S. 932 (1971). Both Bryant and United States v. Brown, 470 F.2d 285 (2d Gir. 1972), rejected the notion that a judge could adopt a uniform policy of nondisclosure. The Seventh Circuit has ruled that reports from the prosecutor's office must always be disclosed to defense counsel. See United States v. Solomon, 422 F.2d 1110 (7th Cir.), cert. denied, 399 U.S. 911 (1970). Cf. United States v. Rosner, 485 F.2d 1213, 1231 n.26 (2d Cir. 1973). 
Malcolm, ${ }^{238}$ make any distinction between material misinformation about a defendant's criminal history and other forms of material misinformation. Yet those courts that have limited disclosure to criminal records seem to have assumed that a defendant can be prejudiced only upon the basis of a mistake in his prior criminal history. This assumption ignores the significant reliance a sentencing judge may place upon incorrect diagnostic or social-history information. ${ }^{239}$

A second deficiency inherent in the approach taken by these courts involves the ease with which their requirements may be evaded. At present, a sentencing judge may deny disclosure, even in those circuits otherwise requiring it, simply by disclaiming reliance upon undisclosed information. ${ }^{240}$ This tactic is obviously subject to abuse and presents an easy alternative for the overworked judge. At a minimum, a disclaimer of reliance upon nondisclosed information should be coupled with an express statement on the record of the factors considered in rendering the sentence. Moreover, if the sentencing judge considers the undisclosed information sufficiently immaterial so as not to require rebuttal, its contents might nevertheless be summarized on the record to ensure that the sentence has not been influenced by material undisclosed information. ${ }^{241}$

To a still uncertain extent, both of these deficiencies appear to have been incorporated in the recent amendment to rule 32(c) of the Federal Rules of Criminal Procedure, which now requires (at the federal level) partial disclosure of the pre-sentence report. Rule 32(c)

238. 432 F.2d 809 (2d Cir. 1970).

239. See United States v. Holder, 412 F.2d 212, 214 (2d Cir. 1969) (trial judge placed primary reliance on such information). An important factor relied upon by the judgc who assigned the death sentence in Williams v. New York, 337 U.S. 241 (1949), was undisclosed information indicating the defendant to be of "a morbid sexuality." 337 U.S. at 244.

Another unresolved ambiguity in Townsend is whether the defendant must show actual reliance by the sentencing judge upon the misinformation. Some courts have interpreted Townsend restrictively to apply only to the situation in which the sentencing record on its face contained a clear error of material fact (such as a confusion of arrest and conviction records) and not to situations in which the record contained unsupported material allegations that the defendant sought to challenge. See, e.g., United States ex rel. Rivers v. Myers, 301 F.2d 782, 784 (3d Cir. 1962). Some recent decisions have stated that the "possibility of misinformation" is sufficient to state a claim under the Townsend principle. See, e.g., United States v. Janiec, 464 F.2d 126 (3d Cir. 1972). Another recent case, United States v. Trevino, 490 F.2d 95 (5th Cir. 1973), requires that actual reliance be shown-an almost impossible task if the court fails to provide a statement of the factors relied upon in imposing the sentence.

240. United States ex rel. Brown v. Rundle, 417 F.2d 282, 285 (3d Cir. 1969). See note 239 supra.

241. In United States v. Carden, 428 F.2d 1116 (8th Cir. 1970), the Eighth Circuit urged the adoption under its supervisory power of a procedure by which the sentencing judge would summarize on the record all material facts relied upon. 
compels disclosure of the pre-sentence report upon request, unless the disclosure would in the court's opinion: (1) reveal a "diagnostic opinion which might seriously disrupt a program of rehabilitation"; 242 (2) compromise confidential sources; or (3) "result in harm, physical or otherwise, to the defendant or other persons." 243 In such cases, the court must summarize all "factual information" that is to "be relied on in determining sentence" and permit the defendant or his counsel to comment thereon. 244 Accordingly, when the information in question falls under an exception, the sentencing judge will apparently remain able to disclaim reliance on information he does not want to hear contested and thus may avoid even summarization. In addition, the use of the limiting phrase "factual information" suggests that the judge may decline to reveal "soft" data, such as personality assessments and similar characterizations of the defendant. $^{245}$

\section{The Right To Require Verification}

To what extent may a judge rely upon unsupported but serious allegations in the pre-sentence report in imposing sentence? For example, once the pre-sentence report has been disclosed, the defendant may discover that in addition to errors of specific fact, which his counsel may correct by reference to the official records, the report also contains vague charges of prior criminal activity. Thus, in United States $v$. Weston, ${ }^{248}$ the defendant, convicted of possession of a small quantity of heroin, was characterized in the pre-sentence report as a major regional drug supplier on the basis of information

242. FED. R. CRnM. P. 32(c)(3)(A). The provisions quoted in the text, along with other amendments to the Federal Rules, were to take effect on Aug. 1, 1975. See 416 U.S. 1001 (1974). On July 31, 1975, Congress revised the Supreme Court's proposed rules and postponed the effective date to Dec. 1, 1975. Federal Rules of Criminal Procedure Amendments Act of 1975, Pub. L. No. 94-64, 89 Stat. 376. The Act adopted the Court's proposed rule 32(c)(3) with only minor revisions. See note 248 supra.

Noting that "the consequences of any serious inaccuracy can be very serious to the defendant," a House report accompanying the Act stressed "that it is essential that the presentence report be completely accurate in every respect." H.R. REP. No. 94247, 94th Cong., 1st Sess. 18 (1975) (emphasis added). This statement of congressional intent may prevent resort to a doctrine of harmless error in cases where a defendant seeks resentencing upon discovering (or becoming able to prove) the existence of material misinformation in the pre-sentence report.

243. Fed. R. Crim. P. 32(c)(3)(A).

244. Fen. R. CRIM. P、 32(C)(3)(B).

245. On the other hand, the rule makes certain diagnostic reports constructively part of the pre-sentence report, FED. R. GRIM. P. 32(c)(3)(E), thus suggesting that such diagnostic conclusions should normally be disclosed.

246. 448 F.2d 626 (9th Cir. 197I), cert. denied, 404 U.S. 1061 (1972). 
supplied by an anonymous informant. ${ }^{247}$ Although most courts have long been prepared to receive information from the defendant in mitigation of charges made in the pre-sentence report, ${ }^{248}$ the problem for the defendant in a situation like that in Weston is that it is often impossible to prove a "negative" fact (for example, that one is not a drug supplier), particularly where the defendant's resources may already have been exhausted by a trial. In Weston, the trial court gave defense counsel 120 days to disprove the charges made in the pre-sentence report. On appeal, the Ninth Circuit decided that this burden could not fairly be placed on a defendant and remanded the case with instructions that the accusations made in the pre-sentence report could not be relied upon unless "amplified by information such as to be persuasive of the validity of the charge there made."240 Weston then appears to fashion a two-pronged rule: first, serious criminal charges may not be made in the pre-sentence report solely on the basis of the uncorroborated testimony of an undisclosed informant; and, second, when the defense challenges the accuracy of the charge, the burden of corroboration must fall upon the prosecution. ${ }^{250}$

247. The court of appeals vacated the sentence. Cases reaching similar results include Shelton v. United States, 497 F.2d 156 (5th Cir. 1974); United States v. Powell, 487 F.2d 325 (4th Cir. 1973); United States v. Espinoza, 481 F.2d 553 (5th Cir. 1973); United States v. Battaglia, 478 F.2d 854 (5th Cir. 1972).

248. Generally, courts today will receive affidavits and even testimony from qualificd sources. See United States v. Holder, 412 F.2d 212 (2d Cir. 1969). Cf. United States v. Needles, 472 F.2d 652, 658 (2d Cir. 1973). Congress has added to rule 32(c)(3)(A) of the Federal Rules of Criminal Procedure a provision authorizing the defendant "at the liscretion of the court, to introduce testimony or other information relating to any alleged factual inaccuracy contained in the presentence report." Federal Rules of Criminal Procedure Amendments Act of 1975, Pub. L. No. 94-64, § 3(33), 89 Stat. 376. The right of the defendant to present such evidence is traccable to the narrower common-law right of allocution, which permitted the defendant only to state reasons why sentence should not be rendered against him. See Barrett, Allocution, 9 Mo. $\mathbf{L}$. REV. 115 (1944). In Green v. United States, 365 U.S. 301 (1961), a plurality of the Court indicated that rule 32(a) was intended to embody this right in expanded form. See 365 U.S. at 304. However, the Court subsequently ruled in a five-to-four decision that the failure of a sentencing judge to offer the defendant an opportunity to make a statement in his own behalf was not, though contrary to the Federal Rules, an error of constitutional stature. Hill v. United States, 368 U.S. 424 (1962). Hill can be narrowly read to hold only that the judge need not ask the defendant if he wishes to speak. If read more broadly to hold that the right of allocution is not constitutionally protected in any form (i.e., that the defendant has no right to address the court), the Hill decision would appear inconsistent with the Court's later holding in Mempa v. Rhay, 389 U.S. 128 (1967), that the right to counsel at sentencing is constitutionally protected.

249. 448 F.2d at 634. Cf. Haller v. Robbins, 409 F.2d 857, 860 (1st Cir. 1969) (requiring the state to prove by a preponderance of the evidence charges contained in a document submitted by the prosecution to the sentencing judge). Compare Shelton v. United States, 497 F.2d 156, 160 (5th Cir. 1974) (defendant must bear the "initial burden" of showing the challenged facts to be untrue).

250. In Nickens v. State, 17 Md. App. 284, 301 A.2d 49 (Ct. Spec. App. 1973), a Maryland court adopted an even stricter rule with respect to the use of hearsay alle- 
A recent Second Circuit case, United States $v$. Needles, ${ }^{251}$ has distinguished Weston on its facts, but agreed in principle with its broader holding. The defendant in Needles pleaded guilty to a charge of possession of an unregistered submachine gun. While the defendant styled himself an inventor engaged in research for the United States Army, the pre-sentence report described him as a major gun dealer. At sentencing, the defendant engaged in an extensive colloquy with the court in which he acknowledged several prior meetings with undercover agents at which gun purchases were discussed and apparently arranged. ${ }^{252}$ This enabled the court to distinguish Weston on the ground that the "key facts" in the presentence report were corroborated by inconsistencies in the defendant's own testimony and by the seizure of a significant quantity of firearms on his arrest. ${ }^{253}$ The court added, however, that in instances where the defendant totally denied a significant charge on which the sentencing court sought to rely, " $[t]$ he probation office or prosecution should be requested to provide substantiation of challenged information submitted to the judge. Likewise in appropriate instances the defendant ought to be allowed to present evidence in the form of affidavits, documents, or even oral statements by knowledgeable persons on matters the court deems material to its decision on the severity of sentence."254

gations. The court ruled that before hearsay allegations could be used, the prosecution must establish "informational reliability" to the satisfaction of the sentencing judge and make "some showing of the credibility of the source." $17 \mathrm{Md}$. App. at -, 301 A.2d at 52. Of particular interest in Nickens is the fact that the court looked in part to fourth amendment "probable cause" cases in evaluating the degree of corroboration that must be shown to justify the use of hearsay allegations; to the extent that other courts are similarly willing to draw analogies to fourth amendment standards, a wealth of precedent could become applicable requiring independent factual corroboration of material hearsay allegations.

251. 472 F.2d 652 (2d Cir. 1973).

252. $472 \mathrm{~F} .2 \mathrm{~d}$ at $656-57$.

253. 472 F.2d at $657-58$.

254. $472 \mathrm{~F} .2 \mathrm{~d}$ at 658. The court further distinguished Weston on the grounds that Needles received a relatively short sentence of three years, and the challenged information in Needles had been acquired by FBI agents, not outside informants, in "face-toface" encounters with the defendant. 472 F.2d at 659.

With the subsequent case of United States v. Rosner, 485 F.2d 1213 (2d Cir. 1973), the Second Circuit appears to have moved closer to the position of the Ninth Circuit in Weston-at least where the challenged information is supplied by the prosecution rather than by the probation office. In Rosner, the prosecution submitted a lengthy memorandum containing numerous detailed charges involving "possible misrepresentations ... and unethical behavior" on the part of the offender, 485 F.2d at 1229, which, the prosecution later conceded, could not have been proved at trial. The memorandum was disclosed to defense counsel only on the day of sentencing. On appeal, the Second Circuit held that the lower court had abused its discretion in not adjourning the sentencing until defense counsel had had "sufficient time for useful examination and rebuttal in view of the one-sided and potentially devastating disclosures of asserted 
Three essential questions remain to be resolved under the rule fashioned in Weston: What kinds of misinformation are of sufficient magnitude to trigger its remedy ${ }^{255}$ To what extent must the sentencing judge explicitly rely upon the asserted misinformation in imposing sentence? ${ }^{256}$ What kinds of adversarial tactics may be utilized at a contested sentencing hearing? The answer to the first of these questions may emerge as courts make increasing use of predictive aids, such as the Board of Parole's Salient Factor Score. To the extent that such rating systems attach numerical weightings to certain items of information, they provide at least a partial definition of materiality in the sentencing context. In addition, by providing standards and a scale by which appellate courts can constructively presume that certain items of information must have been of material importance in the determination of a sentence, such prediction devices also supply a relatively objective substitute for the present requirement of actual reliance.

The final question of the appropriate procedural remedies at resentencing is more difficult to resolve. Although most courts have been extremely reluctant to order evidentiary hearings, the Third Circuit has held that where a defendant denies a damaging confession allegedly made to the investigating probation officer, the sentencing judge should either disregard the purported confession or "permit the defendant to confront and cross-examine the investigator in open court."257 Similarly, the First Circuit has ordered a federal district court to conduct an evidentiary hearing to determine the accuracy of serious charges contained in an ex parte report submitted by a state

bad conduct." 485 F.2d at 1231. Although the Second Circuit did not order an evidentiary hearing, it indicated considerable skepticism toward the use of unsubstantiated hearsay allegations in the pre-sentence report and directed the lower court to permit defense counsel to participate extensively in the process by which the sentencing judge "separate[d] the wheat from the chaff." 485 F.2d at 1230. Cf. Cardaropoli v. Norton, Civ. No. 75-2005 (2d Cir. Sept. 29, 1975); Masiello v. Norton, 364 F. Supp. 1133 (D. Conn. 1973).

255. In United States v. Powell, 487 F.2d 325 (4th Cir. 1973), the Fourth Gircuit commented that not all forms of misinformation would rise to the level of a constitutional violation, but held that misinformation concerning the offender's degree of participation in the crime did rise to constitutional proportions. $487 \mathrm{F.2d}$ at 238 .

256. See Shelton v. United States, 497 F.2d 156, 160 (5th Cir. 1974) (defense entitled to rebut only information "explicitly relied upon"); cases cited in note 239 supra.

257. United States ex rel. Brown v. Rundle, 417 F.2d 282, 285 (3d Cir. 1969). See also United States ex rel. Rivers v. Myers, 384 F.2d 737 (3d Cir. 1967). The court indicated in Brown that the obligation to verify statements of facts through in-court testimony would arise only when the purported statements were of compelling significance and were explicitly denied by the defendant. $417 \mathrm{~F} .2 \mathrm{~d}$ at 285. 
prosecutor to a state court sentencing judge. ${ }^{268}$ These decisions suggest that Williams $v$. New York might ultimately be read narrowly to authorize the receipt of hearsay evidence without foreclosing the issue whether the defendant should be entitled, in appropriate instances, to the use of some adversarial tactics at sentencing.

Although the extent of the defendant's emerging right to challenge the validity of factual information (and require corroboration of material charges) contained in the pre-sentence report remains far from settled, the courts appear to be heading toward a requirement of an informal hearing at which the sentencing judge will resolve specific factual disputes. There are even signs that such a hearing might be subject to a limited form of appellate review to determine if, on the record below, "some evidence" underlay the lower court's factual findings. ${ }^{259}$ Even if such a right is recognized in principle, further questions, such as the defendant's right to challenge unsupported diagnostic evaluations, still remain. Consider the not infrequent case of the damaging one-sentence psychiatric evaluation. In such a case, the need still exists to fashion some procedure by which the diagnosing psychiatrist can be called upon to defend and elaborate his conclusions.

\section{The Right To Exclude Unreliable Information}

Are there kinds of information that are so unreliable or misleading that they should never be included in the pre-sentence report? The defendant who wishes to advance this argument in order to obtain a re-sentencing faces serious obstacles. ${ }^{260}$ Indeed, if Williams

258. Haller v. Robbins, 409 F.2d 857 (1st Cir. 1969). Haller, United States v. Rosner, 485 F.2d 1213 (2d Cir. 1973), and United States v. Solomon, 422 F.2d 1110 (7th Cir.), cert. denied, 399 U.S. 911 (1970), appear effectively to have foreclosed the prosecution from submitting ex parte reports to the sentencing judge, on the theory that the prosecution cannot be expected to present a neutral, balanced portrait of the offender.

259. See United States v. Powell, 487 F.2d 325 (4th Cir. 1973) (requiring re-sentencing where "no evidence" supported the judge's conclusion that the offender had acted as ringleader of a conspiracy). At least two other decisions appear to have adopted such a standard in reviewing parole board factual determinations. See Kohlman v. Norton, 380 F. Supp. 1073 (D. Conn. 1974); Masiello v. Norton, 364 F. Supp. 1133 (D. Conn. 1973). Cf. Thompson v. City of Louisville, 362 U.S. 199 (1960).

260. Not the least of these obstacles is 18 U.S.C. $\$ 3577$ (1970), which provides: "No limitation shall be placed on the information concerning the background, character, and conduct of a person convicted of an offense which a court of the United States may receive and consider for the purpose of imposing an appropriate sentence." However, this provision, part of the Organized Crime Control Act of 1970, seems unconstitutionally overbroad under the doctrine of United States v. Tucker, 404 U.S. 443 (1972), discussed in the text at notes 262-69 infra. In the only decision to have construed section 3557 to date, the Seventh Circuit has commented that, notwithstanding the provision, in some situations consideration of "unproved charges" may invalidate a criminal sentence. United States v. Haygood, 502 F.2d 166, 171 (7th Cir. 1974). 
has any continuing validity it would seem to stand for the proposition that few limits should be placed on the relevancy of the information available to the sentencing judge. ${ }^{201}$ Yet "relevancy" can and should be distinguished from "reliability" if Williams is to be read as not overruling Townsend's principle that inaccurate information may not be relied upon.

A potential counterprinciple to Williams is discernible in the Supreme Court's holding in United States $v$. Tucker ${ }^{282}$ that prior convictions in which the defendant was not represented by counsel may not be considered in rendering sentence. The approach in Tucker is of particular interest because it fashions a per se rule: an entire class of information-prior uncounseled convictions-is banned from the pre-sentence report. The theory underlying Tucker was that because prior uncounseled convictions lack the probative value of convictions obtained in a constitutionally permissible manner, they are misleading and should not be considered by the sentencing judge. It is arguable that the principle of Tucker should be extended to other prior convictions that, in the light of the retroactive application of the major precedents of the Warren Court, must also be seen as having been unconstitutionally obtained. For example, convictions resulting from inadmissible confessions, illegally seized evidence, or racially biased juries might also be subject to exclusion. ${ }^{263}$ On the other hand, it remains uncertain exactly what

261. For an intelligent exposition of this argument, see United States v. Schipani, 315 F. Supp. 253 (E.D.N.Y.), affd., 435 F.2d 26 (2d Cir. 1970), cert. denied, 401 U.S. 983 (1971).

Indeed, in United States v. Siveig, 454 F.2d 181 (2d Cir. 1972), the court of appeals upheld the sentencing judge's right to rely upon charges of which the defendant had been acquitted. Surprising as such a result is, given the axiomatic presumption of innocence, it must at least be noted that the information relied upon was presented at an open trial, was subject to the laws of evidence and to cross-examination, and would thus seem to be of a higher standard of reliability than much of the hearsay information contained in pre-sentence reports. See also United States v. Doyle, 348 F.2d 715, 721 (2d Cir. 1965).

262. 404 U.S. 443 (1972). Tucker was preceded by Burgett v. Texas, 389 U.S. 109 (1967), in which the Court ruled that uncounseled convictions could not be considered in determining the applicability of recidivist statutes.

263. The basic question, however, is the probative value of the conviction rather than its legality. It is therefore arguably possible to distinguish between uncounseled convictions and convictions that would be overturned today on the basis of the exclu. sionary rule; the latter, unlike uncounseled convictions, are not intrinsically untrustworthy, and may provide sufficient assurance that the offender actually did commit the prior illegal act. But see Tarlton v. United States, 507 F.2d 1116 (D.C. Cir. 1974) (making no distinction between these arrest records and allegedly unconstitutional prior convictions in ruling that the FBI must take reasonable steps to assure the accuracy of records that it disseminates). In Tarlton, the plaintiff had relied upon Tucker to challenge the disclosure to his parole board of allegedly unconstitutional prior convictions. 
"misinformation" is proscribed by Tucker. For instance, may the sentencing judge still be informed either that the defendant was previously convicted of a specific charge, but did not have counsel, or that he was indicted on such a charge?264

If Tucker is not to be distinguished to death, one area where its applicability should be acknowledged is the case of arrest records not followed by a conviction. Arrest records possess even less probative value than an uncounseled conviction, and in decisions outside the context of corrections, courts have been quick to deny their use to support a deprivation. ${ }^{265}$ It can be argued, however, that the sentencing judge has not received "misinformation" within the Tucker rule unless the defendant can prove he was unconstitutionally arrested. Although it is generally believed that a significant percentage of arrests not followed by a conviction lack probable cause and therefore are "unconstitutional," 266 few defendants could meet the burden of proving the unconstitutionality of a specific arrest that occurred years earlier. These factors, and the impact of arrest-record data at sentencing, ${ }^{267}$ make it possible to assert that even if Tucker does not directly control the case of the prior arrest record, it is at least an indication that the use of such unreliable information impinges upon constitutional values. ${ }^{268}$ It is thus arguable that before a naked accusatory label such as an arrest record is called to the

264. While allowing the sentencing judge to receive this information would effectively negate the principle of Tucker, it is arguable that the judge would not have been "misinformed" since he would have been told of the unconstitutional nature of the prior conviction. The Ninth Circuit opinion, which was affirmed by the Supreme Court in Tucker, however, instructed the sentencing judge to proceed without "consideration" of prior uncounseled convictions. Tucker v. United States, 431 F.2d 1292, 1294 (9th Cir. 1970), affd., 404 U.S. 443 (1972). This would seem to bar all references to the fact of the prior conviction. But see United States v. Haygood, 502 F.2d 166, 171 n.16 (7th Cir. 1974).

Another evasion of Tucker that undoubtedly will be attempted would be to summarize testimony or evidence offered at the prior trial. To prevent such evasions, it is necessary to read Tucker, in light of its underlying rationale, to proscribe consideration of any information relating to impermissible considerations. In other words, a prior uncounseled conviction should be deemed constitutionally irrelevant, and hence any reference to it should be forbidden.

265. See Schware v. Board of Examrs., 353 U.S. 232 (1957) (use of arrest records hanned in determining admission to the bar); Davis v. Paul, 505 F.2d 1180, 1184 (6th Cir. 1974), cert. granted, 43 U.S.L.W. 3550 (U.S. April 14, 1975) (No. 74-891).

266. See note 71 supra.

267. See Comment, supra note 84, at 869-71.

268. Even prior to Tucker, the Third Circuit held that records of a defendant's prior appearance before a magistrate "have no place in determining sentence." United States ex rel. Jackson v. Myers, 374 F.2d 707, 708 (3d Cir. 1967). Cf. United States v. Pfingst, 477 F.2d 177, 192 (2d Cir.), cert. denied, 412 U.S. 941 (1973). But cf. Catalano v. United States, 383 F. Supp. 346 (D. Conn. 1974). 
attention of the sentencing judge, the state should bear the burden of proving at least some indicia of reliability. ${ }^{200}$

That this result is correct is demonstrated by the incongruity achieved in Menard v. Mitchell. ${ }^{270}$ There, Judge Gesell, on remand from the circuit court, distinguished between the dissemination of FBI arrest records for "employment or licensing purposes," which he enjoined, and their dissemination for "law enforcement purposes," which he permitted after expressly noting that arrest records play a significant role in determining sentences. This distinction

269. It can, of course, be asserted that arrest records should never be used at sentencing. While this article would favor such a restriction, Tucker probably cannot be read so broadly as to prevent any reference to unproved charges of prior criminal activity. See cases cited in note 261 supra. But a basic distinction can be drawn between unsupported arrest records and specific charges of prior criminal activity such as those that might be contained in the prosecutor's file. Arrest records are a far less reliable source of information than specific charges because of the infrequency with which their ultimate dispositions are reported and the problems associated with "suspicion" arrests. See Menard v. Saxbe, 498 F.2d 1017 (D.C. Cir. 1974); Tarlton v. Saxbe, 507 F.2d 1116 (D.C. Cir. 1974). To the extent that these two cases forbid governmental agencies on constitutional grounds to circulate arrest-record data in an incomplete fashion or without reasonable efforts to update and verify such data, the Tucker principle should forbid the probation officer to include such data in his pre-sentence report without similar efforts.

In some very recent instances, courts have begun to express reservations about the consideration at sentencing of unproved criminal charges that the defendant has not admitted. One court has commented that there is an "element of unfairness" in such practices, and speculated that in some instances the defendant might be "entitled to a presumption of innocence ... unless the facts are examined ...." United States v. Haygood, 502 F.2d 166, 169, 171 n.15 (7th Cir. 1974).

270. 328 F. Supp. 718, 727 (D.D.C. 1971), revd. sub nom. Menard v. Saxbe, 498 F.2d 1017 (D.C. Cir. 1974). Judge Gesell's acceptance of the use of arrest records in the exercise of prosecutorial discretion and in sentencing was qualified: "When arrest records are used for such purposes, they are subject to due process limitations within the criminal process, and misuse may be checked by judicial action." 328 F. Supp. at 727. Unfortunately, this caveat overlooks the absence, at present, of any meaningful due process limitations on sentencing data, unless the defendant is able, on his own, to obtain disclosure and prove the existence of a material error.

To date, while many recent cases have been willing to expunge or to enjoin dissemination of arrest records, they have generally done so on nonconstitutional grounds, invoking either the general equity power of the court at the conclusion of a criminal trial, see, e.g., Morrow v. District of Columbia, 417 F.2d 728 (C.D. Cir. 1969); United States v. Kalish, 271 F. Supp. 968 (D.P.R. 1967), federal anti-discrimination legislation, see Gregory v. Litton Systems, Inc., 316 F. Supp. 401 (D.C. Cal. 1970), affd., 472 F.2d 631 (9th Cir. 1973), or special circumstances abridging first amendment or other protected freedoms. See Sullivan v. Murphy, 478 F.2d 938 (D.C. Cir. 1973); United States v. McLeod, 385 F.2d 734 (5th Cir. 1967); Wheeler v. Goodman, 306 F. Supp. 58 (W.D.N.C. 1969). However, the first Menard decision at the court of appeals level contains a suggestion that expungement may be constitutionally required, at least where probable cause for the arrest is not apparent. See Menard v. Mitchell, 430 F.2d 486, 495 n.51 (D.C. Cir. 1970). The Sixth Circuit has recently ruled that it is a denial of the civil liberties protected by 42 U.S.C. $\S 1983(1970)$ to circulate arrest records and mug shots to private parties based only on the fact of arrest. Davis v. Paul, 505 F.2d 1180 (6th Cir. 1974), cert. granted, 43 U.S.L.W. 3550 (U.S. April 14, 1974) (No. 74-891). 
creates a bizarre disparity: Once the incomplete nature of arrest records is acknowledged, the greater potential injury faced by a defendant awaiting sentence would seem to present the stronger case for exclusion.

On appeal from Judge Gesell's decision, the District of Columbia Circuit again faced the issue of arrest records not followed by a disposition, and ordered that the FBI expunge any arrest record from its files when it learns that the subject has either been acquitted or released without charge. ${ }^{271}$ A subsequent case in the same circuit, Tarlton $v$. Saxbe, ${ }^{272}$ went even further, ordering the FBI to take reasonable steps to verify, update, and correct the criminal-history information it collects before circulating such information. ${ }^{273}$ Two aspects of Tarlton are of special relevance. First, the plaintiff was an imprisoned felon who, relying on Tucker, claimed that he had been injured at both sentencing and parole by the use of inaccurate law enforcement records. Second, Chief Judge Bazelon's majority opinion announced that the "gravest constitutional issues" would arise if the statute authorizing the FBI to maintain criminal records ${ }^{274}$ were construed to permit their dissemination without adequate precautions against inaccuracy. ${ }^{275}$

Tarlton, however, declined to address directly the question of what precautions are "reasonable," remanding this question to the district court. Given the unique deprivation facing the offender awaiting sentence, a minimal precautionary effort would seem to include inquiring of the law enforcement agency submitting the report as to whether the offender is still suspected of having committed the alleged crime in question, and requesting a brief summary

271. Menard v. Saxbe, 498 F.2d 1017 (D.C. Cir. 1974), revg. Menard v. Mitchell, 328 F. Supp. 718 (D.D.C. 1971).

272. 507 F.2d 1116 (D.C. Cir. 1974).

273. The court left for subsequent determination the precise steps that the FBI should be required to take, but suggested that the Bureau might be required to expunge arrests after a specified time if no subsequent disposition has been recorded, to give citizens a right of access to their FBI records, or to respond to requests only after checking with the agency from which the information was received for an updated report on the dispositions. 507 F.2d at 1129-30. The court emphasized that mere disclaimers of completeness would not be sufficient and that the principal responsibility for ensuring accuracy must fall upon the state since the "subject of the files, often imprisoned and more often without the intellectual or financial capacity to conduct a personal investigation into the facts of distant arrests or convictions, will seldom be able to effectively challenge the accuracy of information distributed by the FBI before a parole board or sentencing judge." $507 \mathrm{~F} .2 \mathrm{~d}$ at 1127.

274. 28 U.S.C. § 534 (1970).

275. 507 F.2d at 1123-24. Chief Judge Bazelon carefully added, however, that the FBI was under no obligation "to guarantee the accuracy of records" it maintains. 507 F.2d at 1129. 
of the evidence that supported the arrest. ${ }^{276}$ While the extent to which unproved and unadmitted criminal charges should be allowed to influence sentencing remains open to serious question, the direction in which Tarlton points would at least serve to distinguish between specific allegations of prior criminal involvement and bare accusatory labels that contain no corroborative details. 277

Another approach to the problem of exclusion from the presentence report of certain classes of data was taken by the Fourth Circuit in Baker $v$. United States. 278 There the court, relying on its supervisory powers over district courts within its circuit, concluded that allegations of criminal conduct not referable to an "official record" should not be considered by the sentencing judge. ${ }^{270}$ If fol-

276. For example, a short statement that a police officer or other eyewitness had observed the offender commit the crime would serve to distinguish such a case from the far less persuasive case of a "suspicion" arrest.

Beyond these minimal informational requirements, some form of temporal limitation also seems essential. At some point, an arrest entry for which no subsequent disposition is entered should "self-destruct" and be automatically expunged. An ad. visory committee within the Department of Health, Education, and Welfare has recently recommended that arrest records in national databanks be expunged if an indictment does not follow the arrest within one year and a conviction within two years. See RECORDS, Computers, supra note 75, at 245. Similarly, in Cucvas v. Leary, Civ. No. 70-2017 (S.D.N.Y., filed May 21, 1970), the New York City Police Department entered into a final stipulation under which certain juvenile records known as "Y.D. cards" (which essentially resembled arrest records) were to be destroyed as the subject juvenile reached his seventeenth birthday. Cf. YD Study, supra note 71 , at 79.

277. Police records, of course, constitute only one class of "accusatory" records. Labels such as "potential drug abuser" (the characterization involved in Merriken $v$. Cressman, 364 F. Supp. 913 (E.D. Pa. 1973), discussed in note 82 supra) can also be pejorative. Although the basis for the holding in Merriken is open to various interpretations, the case did enunciate a general rule that, from the standpoint of social policy, has equal relevance whether the label arises from law enforcement or other records: "When a program talks about labeling someone as a particular type and such a label could remain with him for the remainder of his life, the margin of error must be almost nil." 364 F. Supp. at 920.

Another case dealing with the use of unsubstantiated accusatory labels is Masiello v. Norton, 364 F. Supp. 1133 (D. Conn. 1973). There, plaintiff had been denied parolc in part because of a pre-sentence report that the court found to be "replete with hearsay, inferences, and conclusions concerning alleged connections" between plaintiff's family and organized crime. 364 F. Supp. at 1136. Concluding that the parole board had wrongly "accepted at face value some loosely-worded, unsupported assertions" in the pre-sentence report for which "no identifiable sources" were cited, Judge Zampano ordered a new parole hearing on the ground that there was "no basis in fact" for the assigned classification. 364 F. Supp. at 1136.

278. 388 F.2d 931 (4th Cir. 1968).

279. 388 F.2d at 934. The court added, however, that information as to the defendant's "general conduct and behavior, as well as his reputation in the community . . . may be treated in the report." $388 \mathrm{~F} .2 \mathrm{~d}$ at 934 .

There have also been several suggestions in recent cases that certain records pertaining to investigatory contacts should either be expunged or curtailed in their circulation outside the recording agency. See United States v. Pfingst, 477 F.2d 177, 192 (2d Cir.), cert. denied, 412 U.S. 941 (1973) (dictum); United States ex rel. Jackson v. Myers, 374 F.2d 707, 708 (3d Cir. 1967). Outside the context of sentencing, courts 
lowed, this restriction to "official records" would limit much of the hearsay allegations of past criminal behavior currently found in presentence reports. Yet another ground for exclusion has been established by cases that have required re-sentencing where illegally seized evidence or inadmissible confessions were relied upon at the initial sentencing. ${ }^{280}$

In summary, cases such as Tucker, Baker, and Tarlton may foreshadow a new approach to sentencing reform-the exclusion of certain classes of information on the ground of insufficient reliability. Inevitably, delicate balancings will be needed to determine whether the probative value of a challenged class of information outweighs its questionable reliability. Once appellate courts have made the initial balancings, however, a major attraction of this exclusionary approach is that it would generally spare the sentencing court the obligation of conducting hearings or making ad hoc decisions as to challenged items of information in the pre-sentence report. Instead, a body of appellate law would develop to ensure consistency in the kinds of information that would be presented to the sentencing judge. Thus, the objection raised in every sentencing reform case since Williams-that the courts would become entrapped in a thicket of technicalities-would be substantially avoided by, for example, a per se rule that arrest records cannot be cited in pre-sentence reports.

\section{Appellate Review of the Decision-Making Process}

Although substantive review of a criminal sentence remains an extraordinary event in the federal courts, the occasions on which federal appellate courts have carefully scrutinized sentences, some-

have generally found records of investigatory contacts easier to expunge than actual arrest records. See, e.g., Paton v. LaPrade, 382 F. Supp. 1182 (D.N.J. 1974) (expungement of record schoolgirl acquired by seeking information from Socialist Workers Party for high school report). Presumably, a case such as Paton follows the general principle enunciated in Menard v. Saxbe, 498 F.2d 1017 (D.C. Cir. 1974), that criminal history records cannot be circulated once it has become clear that the subsequent investigation has proved inconclusive.

280. See, e.g., Verdugo v. United States, 402 F.2d 599 (9th Cir. 1968), cert. denied, 402 U.S. 961 (1971). But see United States v. Schipani, 435 F.2d 26 (2d Cir. 1970).

Federal legislation may have supplied another unexpected limitation on the use of certain information in the pre-sentence report. In People v. Newman, 32 N.Y.2d 379, 345 N.Y.S.2d 502, 298 N.E.2d 651 (1973) (4-3 decision), the New York Court of Appeals ruled that the Federal Comprehensive Drug Abuse Prevention and Control Act of 1970,84 Stat. 1236, 42 U.S.C. \& $242 \mathrm{a}$ (1970), and certain regulations thereunder (see 37 Fed. Reg. 26790, 26800, 26806 (Dec. 15, 1972)), established a standard of absolute confidentiality with respect to the records of federally-financed methadone clinics. Such records, the court held, could not be subpoenaed by law enforcement authorities even on the showing made in that case that the records sought (certain photographs of patients) would be used to identify a homicide suspect. 
times requiring re-sentencings, have increased significantly within recent years. A partial list of the circumstances in which this review has been granted would include cases of reliance on misinformation of a constitutional magnitude, ${ }^{281}$ cases where impermissible criteria involving race or sex have been used, ${ }^{282}$ situations in which the court has failed to receive and consider mitigating circumstances, ${ }^{283}$ cases in which it is shown that the court used a "fixed and mechanical" sentencing policy (generally meaning that the court has assigned the same sentence for a specific crime to all offenders), ${ }^{284}$ sentences that have been influenced by the judge's "revulsion" at the defendant's "social or political views," 285 sentences that reflect punishment imposed by the court for the defendant's failure either to plead guilty ${ }^{280}$ or to accept a judicially approved plea bargain, ${ }^{287}$ sentences in which

281. See, e.g., Townsend v. Burke, 334 U.S. 746 (1948); United States v. Weston, 448 F.2d 626 (9th Cir. 1971). Cases following United States v. Tucker, 404 U.S. 443 (1972), would constitute a sub-category under this heading.

282. See, e.g., United States v. Maples, 501 F.2d 985 (4th Cir. 1974).

283. See United States v. Brown, 479 F.2d 1170, 1172-74 (2d Gir. 1973); United States v. Malcolm, 432 F.2d 809, 818 (2d Cir. 1970). The most typical instance of this type of case may be the refusal of the court to respond to the prosecution's request for a lesser sentence.

284. See, e.g., United States v. Schwarz, 500 F.2d 1350 (2d Cir. 1974); United States v. Hartford, 489 F.2d 652 (5th Cir. 1974); United States v. Baker, 487 F.2d 360 (2d Cir. 1973); United States v. Townsend, 478 F.2d 1072 (3d Cir. 1973); United States v. Daniels, 446 F.2d 967 (6th Cir. 1971). The theory of these cases, best expressed in Daniels, is that Williams v. New York, 337 U.S. 24I (1949), mandates a policy of individualized sentencing that is violated by fixed sentences for any offense, since such a settled policy ignores the character of the defendant.

A close reading of these cases suggests that courts have sometimes employed this standard to engage covertly in substantive appellate review. For example, in Schwarz, the Second Circuit appears first to have determined that the sentence imposed in that case was disproportionate to the circumstances of the offender and from this determination concluded that the sentencing judge must therefore have employed a "fixed and mechanical" policy.

285. See United States v. Brown, 497 F.2d 1170, 1174 (2d Cir. 1973); United States v. Mitchell, 392 F.2d 214, 217 (2d Cir. 1968) (Kaufman, J., concurring).

286. See United States v. Stockwell, 472 F.2d 1186, 1187 (9th Cir.), cert. denied, 411 U.S. 948 (1973); United States v. Wiley, 278 F.2d 500 (7th Cir. 1960). While appellate courts have ruled that the defendant may not be punished for insisting "in good faith" on going to trial, they have also ruled that the defendant who forgoes trial may properly receive special credit for pleading guilty. See Gollaher v. United States, 419 F.2d 520, 530 (9th Gir.), cert. denied, 396 U.S. 960 (1969). The dividing line between these two lines of decision is, to say the least, obscure.

For the special case of an increased sentence imposed upon a retrial following reversal of a conviction, see North Carolina v. Pearce, 395 U.S. 711 (1969), discussed in note 302 infra.

287. See United States v. Stockwell, 472 F.2d 1186, 1187-88 (9th Cir.), cert. denied, 411 U.S. 948 (1973). For the related situation in which the sentencing judge seeks to extract a confession of guilt from the offender at sentencing, see Thomas v. United States, 368 F.2d 941 (5th Gir. 1966) (re-sentencing required where circumstances indicated that sentencing judge had increased the sentence imposed because of defendant's refusal to admit guilt at sentencing). 
the judge was improperly influenced by a belief that the defendant committed perjury at trial, ${ }^{288}$ and, rarest of all, sentences that "shock" the appellate court and yet are within the statutory maximum. ${ }^{289}$

For the most part, these cases have confined the role of the appellate court to a procedural rather than substantive review of the trial court's sentencing decision. Thus, of particular interest are those few cases (generally involving first offenders or youthful draft evaders) where appellate courts have blended procedural and substantive review and suggested that the sentence was excessive in relation to the offense. In $M c G e e v$. United States, ${ }^{280}$ the Second Circuit instructed a trial judge either to alter the two-year sentence given a convicted draft evader or provide "at least a summary explanation of his reasons for declining to do so." 291 In United States $v$. Daniels, ${ }^{292}$ another Selective Service case, the Sixth Circuit ordered a reduced sentence where the sentencing judge noted on the record that he always gave the maximum sentence to draft-evaders. In both cases, unusual mitigating circumstances were clearly present.993 While

288. See United States v. Hendrix, 505 F.2d 1233 (2d Cir. 1974) (judge must believe beyond a reasonable doubt that perjury occurred before he may consider it); United States v. Moore, 484 F.2d 1284, 1288 (4th Cir. 1973); Scott v. United States, 419 F.2d 264 (D.C. Cir. 1969). Contra, United States v. Wallace, 418 F.2d 876, 878 (6th Cir. 1969); Humes v. United States, 186 F.2d 875 (10th Cir. 1951). This rule, premised on the belief that the accused should not be dissuaded from testifying at trial by fear of an increased sentence, constitutes a significant inroad upon the traditional rule that the sentencing judge is free to consider any evidence of criminal behavior, whether or not it resulted in a conviction.

289. See Woolsey v. United States, 478 F.2d 139 (8th Cir. 1973) (en banc) (fiveyear sentence given to Jehovah's Witness in draft-evasion case). Citing Woolsey, the Second Circuit has commented that "cracks in the wall [of appellate nonreview] are beginning to develop . . . " United States v. Brown, 479 F.2d 1170, 1172 (2d Cir. 1973).

290. 462 F.2d 243 (2d Cir. 1972) (Friendly, C.J.).

291. $462 \mathrm{~F} .2 \mathrm{~d}$ at 247. The subsequent history of $M c G e e$ is less encouraging. On remand, the sentencing judge disdained the Second Circuit's clear suggestion that a reduced sentence would be appropriate, and, in an obviously annoyed opinion, again imposed the same sentence with a perfunctory explanation of his reasons. United States v. McGee, 344 F. Supp. 442 (S.D.N.Y. 1972). On appeal, the Second Circuit affirmed, after noting that in certain circumstances a statement of the reasons could "be so perfunctory or otherwise inadequate as to amount to a failure to provide a reasoned explanation." McGee v. United States, 465 F.2d 357, 358 (2d Cir. 1972).

292. 446 F.2d 967 (6th Cir. 1971).

293. Defendant Daniels was a member of Jehovah's Witnesses who refused to perform alternate service on religious grounds; he was sentenced to a maximum five-year term by a judge who noted on the record that he always assigned the maximum penalty to draft evaders. Defendant McGee's conviction on the principal charge (refusal to report for induction) had been overturned on appeal; nevertheless, the trial judge had rejected a motion made pursuant to rule 35 of the Federal Rules of Criminal Procedure to reduce the sentence on the subordinate counts, which involved incidental matters such as failing to file an information questionnaire. The Second Circuit noted that it was the policy of the Selective Service System not to prosecute on such counts alone. 462 F.2d at 246. 
such decisions constitute at best slight inroads on the general rule of nonreview, ${ }^{294} \mathrm{McGee}$ 's insistence on a reasoned explanation and Daniel's refusal to tolerate sentences based on a fixed sentencing policy suggest that the federal courts can find procedural objections when they wish to suggest their displeasure with disproportionate sentences. ${ }^{295}$

Precedents for substantive review of basically dispositional decisions now exist in analogous areas of the law. For example, in one intriguing but terse per curiam decision, ${ }^{206}$ the Supreme Court examined the record before a parole board and then overruled the board's determination, which had been affirmed by the Ninth Circuit, finding that mere on-the-job contacts between a parolee and fellow employees with "police records" constituted an insufficient basis for parole revocation. ${ }^{297}$

The importance of these developments, however, is overshadowed by the failure of the federal courts to take the next logical procedural step in sentencing reform: the imposition of a requirement that the sentencing judge support his determination with findings of fact or at least a statement of reasons. As Judge Frankel has stressed, 208 without such a statement, appellate courts lack a reviewable record. Ideally, to create a record the sentencing judge would cite those specific sections of the pre-sentence report relied upon, as well as other policy factors considered in reaching his decision.

Nevertheless, when confronted in Dorszynski $v$. United States ${ }^{280}$

294. In his dissenting opinion in McGee, Judge Timbers noted that the Second Circuit had never previously reversed or modified a decision on a rule 35 motion for the reduction of sentence. 462 F.2d at 247.

295. It has been suggested that some of these cases, notably United States v. Schwarz, 500 F.2d 1350 (2d Cir. 1974), that proscribe a "fixed and mechanical" approach, might support the use of prediction tables. Project, supra note 58, at 870.71 (outlining, analyzing, and rejecting the argument).

296. Arcinega v. Freeman, 404 U.S. 4 (1971).

297. While the decision was not based on constitutional grounds, it appears to represent an initial instance of substantive review of a parole board determination by the Supreme Court. Other instances of review by a federal court include Kohlman v. Norton, 380 F. Supp. 1073 (D. Conn. 1974); Masiello v. Norton, 364 F. Supp. 1133 (D. Conn. 1973). Recently, federal courts have also shown a willingness to evaluate the reasonableness of punishments imposed upon prison inmates for disciplinary violations. See Wright v. McMann, 460 F.2d 126 (2d Cir. 1972); Dabney v. Cunningham, 317 F. Supp. 57 (E.D. Va. 1970); Fulwood v. Clemmer, 206 F. Supp. 370 (D.D.C. 1962).

298. Judge Frankel has emphasized the need for a statement of reasons both to facilitate appellate review and to increase the perceived equity in the sentencing process in the eyes of the offender. See Frankel, supra note 10, at 9-14. Judge Frankel's position has recently been endorsed by Judge Kaufman, Chief Judge of the Second Circuit. See Kaufman, Foreword: The Sentencing Process and Judicial Inscrutability, Second Circuit Note, 1973 Term, 49 ST. JoHN's L. REv. 215, 220-22 (1975).

299. 418 U.S. 424 (1974). 
with an opportunity to require such findings, ${ }^{300}$ the Supreme Court reiterated its traditional position that the "sentencing function" is vested "exclusively in the trial court." 301 Not only is the result in Dorszynski disappointing, ${ }^{302}$ but its reasoning seems self-contradic-

300. The immediate issue before the Court involved whether a specific statutory provision (section 5010(d) of the Federal Youth Corrections Act, 18 U.S.C. \$ 5005 (1970) required a statement of reasons by the sentencing judge as to why an eligible juvenile defendant would receive "no benefit" from being sentenced under certain special provisions of the Federal Youth Corrections Act. In construing the statute, the Court determined that it was not intended to abrogate the traditional rule that no explanation of a sentence is required. In dicta, the Court added, in a lamentable overstatement of the law: "We begin with the general proposition that once it is determined that a sentence is within the limitations set forth in the statute under which it is imposed, appellate review is at an end." 418 U.S. at 431 (footnote omitted). See also United States v. Velazquez, 482 F.2d 139, 142 (2d Cir. 1973) (characterizing a statement of reasons as a "most salutary practice" but declining to order such a statement); United States v. Phillips, 479 F.2d 1200 (D.C. Cir. 1973); United States v. Brown, 479 F.2d 1170, 1172-73 (2d Cir. 1973).

301. 418 U.S. at 440. However, the Court expressly reserved the constitutional issue whether the due process clause required a reasoned explanation of a refusal to sentence under the special provisions of the Act. 418 U.S. at 431 n.7. Instead, the majority focused on the broader question whether an appellate court has authority to engage in substantive review of a sentence imposed by the trial court where there is no allegation of "inaccurate or improper" information. See 418 U.S. at 431 \& n.7. In so doing, they exposed themselves to Justice Marshall's criticism that there are other reasons why an explanation should be required besides that of facilitating appellate review. 418 U.S. at 455 (Marshall, J., concurring). Cf. note 304 infra.

302. Prior to Dorszynski, several federal courts had begun to edge perceptibly toward the imposition of a requirement of written findings. The fountainhead of this movement was North Carolina v. Pearce, 395 U.S. 711 (1969), in which the Court reasoned that, since the threat of increased sentences on retrial might deter a defendant from protesting constitutional violations at his initial trial, a sentencing judge who imposed a harsher sentence upon retrial would be required to give reasons for the increase and to set forth the factors upon which he relied. While Pearce fashioned an essentially prophylactic rule to protect constitutional rights at the trial stage, and applied only with respect to increased sentences, the Ninth Circuit had subsequently extended Pearce's "chilling effect" rationale to plea-bargaining situations:

[O]nce it appears in the record that the court has taken a hand in plea bar-

gaining, that a tentative sentence has been discussed, and that a harsher sentence has followed a breakdown in negotiations, the record must show that no improper weight was given the failure to plead guilty. In such a case, the record must affirmatively show that the court sentenced the defendant solely upon the facts of his case and his personal history, and not as punishment for his refusal to plead guilty.

United States v. Stockwell, 472 F.2d 1186, 1187-88 (9th Cir.), cert. denied, 411 U.S. 948 (1973).

In addition to reciting the "chilling effect" rationale of Pearce, Stockwell also suggested that appellate courts must intervene to protect against the "appearance of abuse or vindictiveness": "[C]ourts must not use the sentencing process as a carrot and stick .... and they must not create an appearance of such a practice." 472 F.2d at 1187. Accordingly, it has been suggested that the Pearce rule requiring a statement of reasons might be invoked any time the likelihood of an abuse of judicial discretion could be shown. Berkowitz, The Constitutional Requirement for a Written Statement of Reasons and Facts in Support of the Sentencing Decision: A Due Process Proposal, 60 Iowa L. REv. 205, 231 (1975).

Although Dorszynski left open the constitutional issue, currently the most likely route to the adoption of such a requirement for a statement of reasons would appear 
tory. Chief Justice Burger's opinion for the majority distinguishes procedural review of the "judicial process" by which the sentence is imposed, which it encourages, from substantive review, which it finds impermissible, ${ }^{303}$ but ignores the fact that in requesting a statement of reasons appellant was fundamentally seeking only a procedural remedy. The net effect of Dorszynski is to perpetuate an unjustifiable anomaly: Although the due process clause now entitles prisoners denied parole to a written statement of reasons, ${ }^{304}$ that same clause is apparently not applicable when an identical request is made at the sentencing stage.

\section{B. The Future of Procedural Reform}

Since Williams $v$. New York, ${ }^{305}$ a fundamental assumption of the law of sentencing has been that the rehabilitative purposes of modern correctional philosophy justify a relaxation of the procedural formalities that surround virtually every other form of judicial proceeding. ${ }^{306}$ Long criticized and increasingly eroded, this rehabilitative model has now been substantially abandoned by the United States Board of Parole. With the adoption of a "national paroling policy"307 that utilizes a static and statistically derived classification

to lie in an appeal to the general supervisory powers of federal circuit courts. In both United States v. Velazquez, 482 F.2d 139 (2d Cir. 1973), and United States v. Brown, 479 F.2d 1172 (2d Cir. 1973), the Second Circuit appears to have considered seriously such a rule, refusing to adopt it in Velazquez in part because the defendant failed to make a timely request for a statement of reasons. See $482 \mathrm{~F} .2 \mathrm{~d}$ at 142. Indeed, there would now seem to exist compelling reasons for the adoption of such a rule in the Second Circuit in order to achieve consistency with the treatment now afforded offenders seeking parole under United States $e x$ rel. Johnson v. Chairman of N.Y. State Bd. of Parole, 500 F.2d 925 (2d Cir. 1974). For an interesting discussion of the parameters on the supervisory powers of the circuit courts in reviewing sentencing decisions, see Thomas v. United States, 368 F.2d 941 (5th Cir. 1966).

303. 418 U.S. at 443, quoting United States v. Hartford, 489 F.2d 652, 654 (5th Cir. 1974).

304. See Cardaropoli v. Norton, Civ. No. 75-2005 (2d Cir. Sept. 29, 1975); United States ex rel. Johnson v. Chairman of N.Y. State Bd. of Parole, 500 F.2d 925 (2d Cir. 1974); Monks v. Parole Bd., 58 N.J. 238, 277 A.2d 193 (1971); Solari v. Vincent, 46 App. Div. 2d 453, 363 N.Y.S.2d 332 (1975). The Johnson majority gave several reasons why a statement of reasons by the parole board should be required: (1) to facilitate judicial review, 500 F.2d at 930; (2) to promote "thought by the decider" and "compel" him "to cover the relevant points and eschew irrelevancies," 500 F.2d at 931, quoting M. FrANKEL, supra note 1 , at 40-4I; (3) to prevent arbitrary denials of parole, $500 \mathrm{~F} .2 \mathrm{~d}$ at $932 ;(4)$ to promote rehabilitation by relieving prisoner frustrations created by a failure to explain decisions, 500 F.2d at 932-33; and (5) to establish a uniform body of rules to minimize disparities. $500 \mathrm{~F} .2 \mathrm{~d}$ at 933 . This summary of justifications needs only the word "sentence" substituted for "denials of parole" to constitute an intelligent statement of the need for similar sentencing reform.

305. 337 U.S. 241 (1949).

306. Kadish, supra note 11 , at 905.

307. See 28 C.F.R. $\$ 2.20$ (1974); text at notes 187-92 supra. 
system for the determination of parole eligibility, the Board of Parole has essentially chosen an "incapacitation" model: By using criteria that focus almost exclusively on the relative risk of recidivism that certain classes of offenders represent for society, the Board has implicitly acknowledged that it is unable to judge or measure rehabilitative progress ${ }^{308}$ and so will confine its efforts to seeking to incapacitate offenders in terms of their marginal level of dangerousness. To a considerable degree, this change of policy has foreclosed the ability of the federal trial judge to sentence on the traditional assumption that the period of incarceration actually served will be a function of the offender's progress toward rehabilitation. ${ }^{309}$

For two reasons, this change of policy has also substantially undercut the rationale for appellate court deference to the sentencing judge. First, it is now increasingly difficult to assert that the benevolent intent of the correctional system justifies procedural informality. Second, the claim that the sentencing judge is more familiar with, and thus better able to evaluate, the offender is substantially vitiated when the Board of Parole (as the administrative agency possessing the greatest expertise in such matters) acknowledges that it is unable to evaluate offenders on an ad hoc individualized basis, notwithstanding its greater opportunity to study the offender. In short, if the Board of Parole believes that it can best deal with offenders through the use of generalized demographic criteria as set forth in formalized rules, the case for unfettered discretion at the sentencing stage becomes increasingly tenuous.

Given this backdrop, it seems likely that the pace of procedural reform of the sentencing process will soon accelerate. ${ }^{310}$ Ultimately,

308. Project, supra note 58, at 826-28.

309. The question of how authority should properly be allocated between sentencing judge and parole board is beyond the scope of this article. For an excellent analysis of this issue, see $i d$. at 886-97. While federal judges may, to a limited extent, succeed in "overriding" the Guidelines, id. at 883, the Yale Project concluded that "judicial sentencing purposes" and "judges' expectations" have been impeded by the Board of Parole's action. Id. at 894 .

310. Subsequent to the Board of Parole's adoption of its guidelines, several courts have held the Board to be within the coverage of the Administrative Procedure Act, 5 U.S.C. $\$ \$ 551-59(1970)$, and have subjected it to a variety of procedural requirements previously thought inapplicable. See Pickus v. Board of Parole, 507 F.2d 1107 (D.C. Gir. 1974); Mower v. Britton, 504 F.2d 396 (10th Cir. 1974); King v. United States, 492 F.2d 1337 (7th Cir. 1974). While the Administrative Procedure Act is not applicable to courts, the point here is that once formal rules and standards are promulgated (or recognized) by courts or agencies, the standard of judicial review applied to their subsequent decisions inevitably becomes more strict because appellate courts then have manageable guidelines against which to test whether the lower court or agency has complied. Thus, to the extent that the sentencing courts come to use or consider guidelines such as those proposed by the Board of Parole (as some already have, see Project, supra note 58, at $878 \mathrm{n} .394$ ), appellate courts can, with considerably greater ease, enforce a higher degree of procedural formality. 
the only rational course this reform can take is to integrate into the sentencing stage the standards applicable to parole. Regardless of the allocation of authority between the trial courts and the parole boards, a disparity between the procedural rights the offender has at sentencing and those he possesses at parole can seldom be justified when both processes vitally affect the offender's interest in his liberty.

\section{G. Substantive Reform: The Roads Not Yet Taken}

Procedural reform has its inevitable limitations. In particular, it is only indirectly related to the two most frequently voiced criticisms of the contemporary correctional system: the excessive severity of the sentences imposed, ${ }^{311}$ and the tendency for the system to discriminate against members of minority groups. ${ }^{812}$ This section will examine the degree to which legal theories intended to redress these two deficiencies have been accepted.

\section{The Concept of Proportionality}

On rare occasions federal courts have found the length of a criminal sentence to be so excessive as to constitute "cruel and unusual punishment" within the meaning of the eighth amendment. ${ }^{313}$ These decisions have generally been predicated on a finding that the statutory minimum sentence was excessive in relation to the offense; thus construed, these cases have constituted a limitation on the legislative rather than the judicial sentencing determination.

A 1972 California supreme court decision, In re Lynch, ${ }^{314}$ boldly reversed this rule, holding that the comparison must be between the maximum sentence and the offense. Even assuming that courts must look to the maximum rather than the minimum penalty, how does a court derive standards by which to judge whether a sentence is disproportionate? Lynch offered three tests: First, the court must evaluate the dangerousness of the offense and the offender to society, ${ }^{815}$ second, the court must compare the "challenged penalty with the

311. See note 8 supra.

312. See W. GaxuIN, supra note 6, at 28-33; Comment, supra note 84, at 861 n.17.

313. The leading case in this area is Weems v. United States, 217 U.S. 349 (1910), in which the Supreme Court invalidated a sentence of 15 years imprisonment at hard labor plus certain civil penalties on the ground that even the minimum sentence provided in the statute (12 years) would have been grossly disproportionate to the severity of the offense (a fraudulent embezzlement involving falsification of govern. ment records). For a discussion of cases following or distinguishing Weems, see Singer, Sending Men to Prison: Constitutional Aspects of the Burden of Proof and the Doctrine of the Least Drastic Alternative as Applied to Sentencing Determinations, 58 CORNELL L. REV. 51, 64-7I (1972).

314. 8 Cal. 3d 410, 105 Cal. Rptr. 217, 503 P.2d 921 (1972).

315. 8 Cal. $3 \mathrm{~d}$ at 425-26, 105 Cal. Rptr. at 226-27, 503 P.2d at 930-31. 
punishments prescribed in the same jurisdiction for different offenses which ... must be deemed more serious," 316 and, third, the court must make an inter-jurisdictional comparison, examining the severity of the penalties imposed on other jurisdictions for the same offense. ${ }^{317}$

Without discounting the significance of Lynch, it seems likely that it will provide a remedy primarily for offenses that are only

316. $8 \mathrm{Cal} .3 \mathrm{~d}$ at $426,105 \mathrm{Cal}$. Rptr. at $227,503 \mathrm{P} .2 \mathrm{~d}$ at 931 (emphasis original).

317. 8 Cal. 3d at 427-28, 105 Cal. Rptr. at 234-35, 503 P.2d at 938-39. Lynch is analyzed in Dershowitz, supra note 8, at 328-31.

Lynch has been extended by the California supreme court in several subsequent cases. In In re Foss, 10 Cal. 3d 910, 112 Cal. Rptr. 649, 519 P.2d 1073 (1974), it held that a sentencing condition that the offender not be considered for -parole for a minimum of 10 years, which was required by a California recidivist statute that an earlier conviction had made applicable, constituted cruel and unusual punishment as applied to the individual circumstances of a narcotics addict convicted of selling heroin, primarily because the restriction ignored the extent to which the repetition of the earlier illegal behavior was attributable to addiction. $10 \mathrm{Cal}$. 3d at 920-21, 112 Cal. Rptr. at 655-56, 519 P.2d at 1081. Thus Foss seems to shift somewhat the focus of Lynch's first criterion from the dangerousness of the offender to the question whether there exist exculpatory factors. See also People v. Schueren, $10 \mathrm{Cal}$. 3d 553, 111 Cal. Rptr. 129, 516 P.2d 833 (1973).

In People v. Wingo, 14 Cal. 3d 169, 121 Cal. Rptr. 97, 534 P.2d 1015 (1975), the California supreme court applied the Lynch rule for the first time to a violent crime (aggravated assault on a 72-year old man). In Wingo, the offender had received a term of from six months to life imprisonment. The court ordered the California Adult Authority to make an initial determination of the maximum sentence to enable the courts on review to determine whether the term would be disproportionate to the offense. Finally, in In re Rodriguez, 14 Cal. 3d 639, 122 Cal. Rptr. 552, 539 P.2d 384 (1975), the court required the Adult Authority to fix promptly the actual maximum term of all prisoners subject to the Indeterminate Sentence Law, allowing reviewing courts to apply the Lynch criteria to the actual terms. The case may well constitute the coup de grace for the California variety of indeterminate sentencing.

For decisions in other states comparable to Lynch, see Faulkner v. State, 445 P.2d 815, 818-19 (Alas. 1968), and People v. Lorentzen, 387 Mich. 167, 177-79, 194 N.W.2d 827 (1972). But see People v. Broadie, 37 N.X.2d 100, 371 N.Y.S.2d 471, 332 N.E.2d 338 (1975). At the federal level, the Sixth Circuit has recently applied what appears to be the Lynch criteria in holding in the case of a first-time offender that the imposition of consecutive sentences of $10-20$ years for possession of marijuana with intent to sell and 20-40 years for the sale of marijuana constituted cruel and unusual punishment in violation of the eighth amendment. Downey v. Perini, 44 U.S.L.W. 2034 (6th Cir. July 3, 1975). The Sixth Circuit noted first that the Ohio statute in question imposed more severe minimum penalties for the sale and possession of marijuana than existed in any other state and, second, that such penalties exceeded the minimum sentences in Ohio for more severe crimes such as rape, kidnapping, and armed robbery. In contrast to Lynch and Wingo, however, the Sixth Circuit refused, in measuring the proportionality between the crime and the sentence, to consider either the maximum sentence imposed or the discretionary decision of the sentencing judge to make the sentences consecutive (thus ensuring an effective 30-60 year sentence). Rather, the court announced that the scope of its review was limited to "an attack on the constitutionality of the statute itself." 44 U.S.L.W. at 2034. Thus, although Downey constitutes one of the first federal decisions to find a sentence unconstitutional solely on the basis of the length of sentence imposed, it limits the Lynch approach by reviving the Weems limitation that the statute itself impose a minimum punishment that is unconstitutional. 
moderately serious. ${ }^{318}$ At issue in Lynch was an indeterminate sentence of up to life imprisonment for the relatively innocuous charge of indecent exposure. ${ }^{319}$ The court was thus able to compare the severe sentence imposed upon the defendant to both the lesser sentences imposed for more serious crimes in California and to sentences imposed for indecent exposure in other states.

When, however, the reviewing court is confronted with a severe sentence imposed for a more serious crime, appellate courts have shown little willingness to intervene, even in relatively appealing circumstances. This reluctance is illustrated by the recent case of Rogers $v$. State, ${ }^{320}$ in which a seventeen-year old Black received a sentence of life imprisonment without possibility of parole for the crime of rape, notwithstanding the fact that he had no prior criminal record. ${ }^{321}$ In a case like Rogers it is unlikely that a court will find support for a determination that the sentence imposed is excessive by looking either to punishments prescribed within the same jurisdiction for different offenses deemed more serious or to the sentences imposed in other jurisdictions for the same crime. If a court is to grant relief in such a case it must rely exclusively on the first test in Lynch and say that neither the offense nor the offender was so dangerous as to necessitate life imprisonment. ${ }^{322}$ Despite inviting

318. But cf. People v. Wingo, 14 Cal. 3d 169, 121 Cal. Rptr. 97, 534 P.2d 1015 (1975).

319. Defendant Lynch was subject to such a sentence because of a prior conviction on the same charge several years earlier. Mitigating the severity of this second conviction, however, was the fact that the "indecent exposure" had occurred late at night in the supposed privacy of defendant's own parked car.

In general, courts seem to have been the most aggressive in imposing substantivc limitations upon the sentencing power in the area of recidivist statutes. In addition to Lynch, see Hart v. Coiner, 483 F.2d 136 (4th Cir. 1973), cert. denied, 415 U.S. 983 (1974); In re Foss, 10 Cal. 3d 910, 112 Cal. Rptr. 649, 519 P.2d 1073 (1974), and People v. Morton, 48 App. Div. 2d 58, 367 N.Y.S.2d 595 (1975). Since the sentence imposed under such recidivist statutes is often a mandatory one (or at least one not fully the product of the sentencing judge's own unfettered discretion), these cases necessarily constitute a lesser incursion upon the citadel of judicial discretion.

320. 257 Ark. 144, 515 S.W.2d 79 (1974), cert. denied, 43 U.S.L.W. 3571 (U.S. April 21, 1975).

321. 257 Ark. at $\rightarrow, 515$ S.W.2d at 87. Counsel for the defendant also stressed that the victim had not been otherwise injured.

322. Such a finding could also be couched in the language of the "less drastic means" doctrine. In his dissent to the denial of certiorari in Rudolph v. Alabama, 375 U.S. 889 (1963), Justice Goldberg advocated testing the constitutionality of a punishment by ascertaining whether it went beyond what was necessary to achieve the expressed legislative intent of the governing statute. 375 U.S. at 889-91. From this perspective, a court could say that society's legitimate interests in creating an adequate deterrent to rape and in incapacitating recidivists could be satisfied by measures less drastic than life imprisonment: Certainly, release of the offender at some point would be possible (even if only at middle age) without him posing a danger of repeating the same offense. A few cases have approached such a result in fact situations similar to Rogers. See Ralph v. Warden, 438 F.2d 786 (4th Cir. 1970), cert. denied, 408 U.S. 942 (1972); Workman v. Commonwealth, 429 S.W.2d 374 (Ky. 1968). Cf. Singer, supra note 313 , at 67. See generally Morris, supra note 16, at 1162-64. 
circumstances-a youthful offender, the absence of a prior record, a relative lack of violence, and the possibility that the severity of the sentence was attributable to racial bias-the Arkansas supreme court refused to consider the claim of "cruel and unusual" punishment, citing instead the traditional doctrine that sentences between the statutory minima and maxima will not be disturbed. ${ }^{323}$ On appeal, the United States Supreme Court denied certiorari without a dissenting opinion. . $^{34}$

In short, the immediate outlook for expansion of the doctrine of proportionality is limited. ${ }^{325}$ Courts are reluctant to confront the most difficult issues and appear willing to intervene only when, as in Lynch, they can compare the sentence imposed with relatively objective standards. ${ }^{328}$

\section{The Problem of De Facto Discrimination}

To date, courts have summarily rejected equal-protection-based attacks on sentencing disparities. ${ }^{327}$ In response to the claim that Blacks tend to receive longer sentences than Whites, they have replied by citing the ancient tradition of judicial discretion and the benevolent intent underlying the policy of individualized sentences. But, as courts come to use formalized prediction tables, ${ }^{328}$ these argu-

323. 257 Ark. at - , 515 S.W.2d at 87.

324. 43 U.S.L.W. 3571 (April 21, 1975).

325. For example, the New York State Court of Appeals, although ostensibly espousing the Lynch doctrine, refused to find the mandatory maximum life sentence for the sale of heroin unconstitutionally disproportionate. People v. Broadie, 37 N.Y.2d 100, 371 N.Y.S.2d 471, 332 N.E.2d 338 (1975). With the Lynch approach in mind the court found that, "[c]ompared both 'internally' to punishments for other crimes under [New York 1]aw, and 'externally', to punishments imposed elsewhere for the same or similar offenses, the narcotics laws are relatively severe, but not irrationally so, given the epidemic dimensions of the [drug] problem." 37 N.Y.2d at 117, 371 N.Y.S.2d at 480-81, 332 N.E.2d at 345. Rejecting the defendant's arguments that a life sentence could not serve a rehabilitative function, the court found that the legislature could reasonably have designed the penalty with the purposes of isolation and deterrence in mind. This analysis, even if one accepts its premise that the harm inflicted by drug trafficking exceeds that of almost all violent crimes, fails to consider why a lifetime of isolation is needed to incapacitate the individual or to deter adequately potential offenders, given their principal interest in risk of apprehension rather than sentence length.

326. An exception may exist, however, to the extent that the offender can show disparities in the length of sentences imposed that adversely affect members of minority groups. See Furman v. Georgia, 408 U.S. 238, 249-57 (Douglas, J., concurring), 363-66 (Marshall, J., concurring) (1972).

327. See, e.g., Andrus v. Tucker, 421 F.2d 290 (10th Cir. 1970); Morrison v. Walker, 404 F.2d 1046 (9th Cir. 1968).

328. For example, it is now reported that pre-sentence reports in the Southern District of New York contain the estimated results that would be achieved under the Board of Parole's Salient Factor Score. Project, supra note 58, at 878 n.334. To the extent that courts rely on such information, it is logically inconsistent for them to assert the defense of "rehabilitative purpose" in reply to an equal protection based challenge. 
ments may have less force: Such tables present a far more inviting subject for scrutiny than does the institution of judicial discretion.

Assuming that the use of prediction tables has a material adverse impact on the opportunities of members of minority groups to obtain probation or reduced sentences, what standard of judicial review should an appellate court apply to an offender's claim that the use of such tables is discriminatory? On the one recent occasion that the Supreme Court decided a case involving an equal protection based attack on sentencing-classification procedures, it held that a "rational basis" test would apply. Yet, that case, McGinnis $v$. Royster, ${ }^{329}$ dealt only with the relatively narrow issue whether prisoners must be granted credit against their sentences for pre-conviction "jail time." In reply to the argument that the denial of this credit prejudiced minority group members (since they were less able to obtain bail), the Court responded, in part, that the purpose of incarceration was to rehabilitate offenders; thus, because pre-trial detention facilities were generally not equipped to offer rehabilitative programs, it was not unreasonable for the state to consider only time served in a rehabilitation-oriented setting, such as prison. ${ }^{830}$ This justification, however, would seem unavailable when the subject of judicial scrutiny is a prediction table that disregards the question of rehabilitation.

Attacks on the constitutionality of prediction tables might be framed by arguing that they violate the constitutional prohibition on punishment of "status," 331 that they constitute irrebutable presumptions because they ignore redeeming information, ${ }^{332}$ or that they constitute a "fixed and mechanical approach" to sentencing, which violates the constitutional policy in favor of individualized discretion. ${ }^{333}$ While each of these arguments may be disputed on its respective merits, ${ }^{334}$ the context of sentencing is not yet ripe for the assertion of these particular theories, since the sentencing

329. 410 U.S. 263,270 (1973).

330. 410 U.S. at $270-73$.

331. See Robinson v. California, 370 U.S. 660 (1962) (invalidating punishment for "crime" of being narcotics addict); Papachristou v. City of Jacksonville, 405 U.S. 156 (1972) (vagrancy statute invalidated); Ricks v. District of Columbia, 414 F.2d 1097, 1110 (D.C. Cir. 1968) ("Statistical likelihood that a particular societal segment will engage in criminality is not permissible as an all-out substitute for proof of individual guilt" (footnote omitted)).

332. Cf. Vlandis v. Kline, 412 U.S. 441 (1973). Specifically, prediction tables ignore any facts-whether good or bad-that have not been given an assigned rating based upon sufficient prior experience.

333. See note 284 supra and accompanying text.

334. See Project, supra note 58, at 863 n.266, 870-77. 
judge continues to exercise discretion and receives an abundance of information in addition to prediction-table rankings.

In other recent Supreme Court cases involving the equal protection clause, commentators have discerned the development of an intermediate "reasonable means" standard of judicial scrutiny that lies between the "mere rationality" test of McGinnis and the strict scrutiny test that the Warren Court applied when it discovered a "fundamental interest" or a "suspect classification." 335 Essentially, the emerging test focuses on the legislative means employed to reach a permissible end and requires that the end be substantially furthered by the means chosen..$^{336}$ Given the relatively greater efficiency of the prediction table in comparison with other techniques, there seems little doubt that prediction tables could survive this intermediate form of judicial scrutiny.

As a result, the offender seeking to challenge a prediction table employing factors relating to race or economic status would seem to be forced back upon the argument that use of these factors involves a "suspect classification" or infringes upon a "fundamental interest." 837 Under traditional equal protection analysis, a state attempting to utilize a suspect classification bears the burden of proving that the classification is necessary to promote a "compelling" state interest and that no less drastic means exist to further the interest. ${ }^{338}$

335. See Gunther, Foreword: In Search of Evolving Doctrine on a Changing Court, The Supreme Court, 1971 Term, 86 HARv. L. REv. I (1972). Compare Note, Boraas v. Village of Belle Terre: The New, New Equal Protection, 72 MICr. L. REv. 508 (1974).

336. See Gunther, supra note 335, at 18-27. Professor Gunther cites James v. Strange, 407 U.S. 128 (1972); Jackson v. Indiana, 406 U.S. 715 (1972); Humphrey v. Cady, 405 U.S. 504 (1972); Reed v. Reed, 404 U.S. 71 (1971) (all the foregoing being unanimous decisions); and Weber v. Aetna Cas. \& Sur. Co., 406 U.S. 164 (1972) as among the decisions employing this standard.

The decisions employing this standard in the context of alleged de facto racial discrimination bear a marked resemblance in their reasoning to Griggs v. Duke Power Co., 401 U.S. 424 (1971), the leading Supreme Court case dealing with federal antidiscrimination legislation. Compare Griggs with Berkelman v. San Francisco Unified School Dist., 501 F.2d 1264, 1267 (9th Cir. 1974) (holding that the disproportionate adverse impact on racial minorities of special academic high schools required the state to demonstrate that its legitimate ends were substantially furthered by the classification technique employed). Thus, it seems possible that the Griggs method of analysis, which in effect permits the plaintiff to make a prima facie case by a statistical demonstration of a disproportionate adverse impact on a protected class, subject to rebuttal by the employer if it can demonstrate that the challenged means are suffciently closely related to its legitimate ends, may also provide an infuential model for a court in search of appropriate standards. See note 340 infra.

337. See, e.g., Graham v. Richardson, 403 U.S. 365 (1971); Loving v. Virginia, 388 U.S. I (1967); McLaughlin v. Florida, 379 U.S. 184 (1964).

338. Chief Justice Burger has criticized the linked use of compelling state interest and less drastic means, stating that it represented an "insurmountable standard" and an absolute bar to legislation. Dunn v. Blumstein, 405 U.S. 330, 363-64 (1972) (dissenting opinion). 
Although application of this test would probably prevent the use of the "suspect" factors, there are signs that unless one of the traditionally suspect classifications-race, alienage, or national originare involved, the Supreme Court will not invoke the "suspect classification" form of constitutional analysis. ${ }^{339}$ Even for the minority group offender, a significant barrier remains in demonstrating to a court that the use of criteria that on their face appear racially neutral, but that substantially overlap with racial status, constitutes the use of a suspect classification. . $^{340}$ Thus, the relevance of the suspect classification doctrine to the problem of sentencing classifications is limited.

Yet, to the extent that prediction tables are given material weight in the determination of sentence, some standard of judicial review must be found that can balance the strong interest of the state in utilizing an accurate system for the identification of recidivists against the constitutional imperative that invidious classifications not be made on the basis of race. In such situations, courts are traditionally expected to accommodate both values to the maximum extent possible. Here, an accommodation seems best effected by a limited use of the less drastic means doctrine. A court could utilize this approach by asking the following questions with respect to each racially linked predictive factor: What loss of predictive efficiency would the state sustain if it were required to omit the factor from its prediction table? Would the state still possess an adequate and efficient means for the differentiation of offenders according to their future risk of recidivism if a specific factor or factors shown to be closely racially linked were eliminated? Thus framed, the issue would not be whether prediction tables could be used, but to what extent the state should sacrifice a degree of predictive efficiency to other considerations.

To the extent that the prediction table's efficiency is not materially reduced by the elimination of the racially tainted factor, it could be said that the state possesses a less restrictive means of obtain-

339. See, e.g., Stanton v. Stanton, 43 U.S.L.W. 4449 (U.S. April 15, 1975); San Antonio Independent School District v. Rodriguez, 411 U.S. 1 (1973) (holding in part that wealth and poverty need not be "suspect classifications"); Geduldig v. Aiello, 417 U.S. 484 (1974).

340. Some degree of overlap between criteria racially neutral on their face (e.g., "receipt of public assistance," "single parent household," "urban living environment," and "juvenile police record") and racial status must realistically be acknowledged as generating a "suspect classification." The issue is how great a degree of overlap must exist before a court will recognize that such seemingly neutral criteria in fact mask racial status. It is in this area that a case such as Griggs v. Duke Power Co., 401 U.S. 424 (1971), with its emphasis on statistical correlations, may supply a useful precedent, notwithstanding its nonconstitutional origins. 
ing its legitimate objective-use of the same table minus the tainted factor. ${ }^{341}$ Even where the loss of predictive efficiency is material, the doctrine might be used to claim that the state must nevertheless demonstrate that the tainted factor cannot be replaced by other equally accurate criteria. ${ }^{342}$

341. To illustrate how such a test might be employed, assume a prediction table, similar to the Board of Parole's Salient Factor Score, that classifies offenders into three risk categories: "good" (meaning an 80 per cent chance of "success" over a specified period after release on parole), "fair" (meaning a 65 per cent chance), and "poor" (meaning a 50 per cent chance). Next assume that a given criterion (such as failure to obtain a high school diploma) is racially linked in that it is disproportionately present among Black offenders. Finally, assume that the elimination of this raciallylinked factor would reduce the predictive efficiency of the table such that the "good" rating would signify only a 75 per cent chance of success and the "fair" rating only a 60 per cent chance (the residual "poor" rating would remain at 50 per cent). What injury would the state suffer by being forced in such a context to use the revised table without the tainted factor? The state is not being required to release any offender at any risk level; rather, the only restraint imposed is upon its ability to identify a select group of "good" risks through the use of a discriminatory criterion.

One limitation must be noted on the concept that racially-linked criteria should not be used in determining sentence: Factors showing personal culpability or instability (for example, prior convictions) should always be seen as a permissible basis for differentiation regardless of their disproportionate presence in minority group populations since such factors relate to individual status, not group status. While the argument can be made that prior convictions should not affect the length of sentence where the offender has already been punished for the prior conviction (since, according to this argument, enhanced punishment because of the prior conviction constitutes a species of "double jeopardy" with regard to the first conviction), courts have been quick to reject this argument summarily. See United States v. Haygood, 502 F.2d 166, $168 \mathrm{n} .4,169-70$ (7th Cir. 1974). This result seems correct to the extent that it is reasonable to infer from the prior conviction that the offender poses a marginally greater risk of recidivism than otherwise similarly situated offenders.

342. For example, the Board of Parole's Salient Factor Score does not employ some factors that are generally agreed to possess a high correlation with recidivism. An example is the age of the offender, young offenders being much more likely to engage in subsequent illegal acts than middie-aged offenders. See D. GLASER, ThE EFFEcTrveness of a Prison and Parole System 36-37 (1964). In a sense then, a middle-aged Black offender whose risk-rating is affected by racially sensitive criteria may be held hostage within a risk category that his individual circumstances do not justify, given the lower prospect of recidivism that his age creates. A problem exists with this argument, however, which becomes evident when we consider the case of a white offender who claims that he also is held hostage within an overly severe risk category unless he is permitted to demonstrate through the use of racially sensitive variables that he poses a lesser risk of recidivism than minority group offenders. For, if we allow each offender to demonstrate, by adducing additional criteria, the extent to which he poses a lesser risk than other persons assigned to the same risk category, the problem of discriminatory criteria re-enters by the back door: The offender who is the beneficiary of a racially sensitive factor can be expected to point out that he should be treated more leniently than otherwise similarly situated offenders who do not share the racially sensitive factor. Consistency then requires that an offender not be permitted to use for exculpatory purposes factors that applicable standards of fairness bar the state from using.

On the technical level, use of additional criteria not considered by the prediction table may not be generally feasible without a new validation study. Thus, as a practical matter, the offender may be limited to showing either that omission of the tainted factor would not materially reduce the table's efficacy or that other tables employing less objectionable criteria could be used without a material loss in predictive capacity. 
It is generally agreed that the doctrinal precondition for the use of the less drastic means doctrine is the presence of either a "fundamental interest" or a "suspect classification." 343 Furthermore, it would seem clear that the offender's interest in his own liberty and in freedom from unnecessary incarceration represents his penultimate fundamental interest, exceeded only by his interest in avoiding capital punishment..344 Does this mean then that the nonminority group offender can also utilize the less drastic means doctrine to object to differentiation in treatment on the basis of prediction tables that make punishment effectively depend upon his status? While there is merit in this position, ${ }^{345}$ it faces the problem that prediction tables arguably already represent the use of less drastic means (except to the extent that they utilize "suspect classifications" for which no "compelling" state interest can be shown), because such tables undeniably relate punishment to the future risk of recidivism; ;46 in this light, such tables can be said not to infringe unneces-

343. See, e.g., Gunther, supra note 335, at 8-10, 24 .

344. This is the point at which Professor Singer begins his analysis of what he terms the "least restrictive alternative" doctrine. See Singer, supra note 313.

In Speiser v. Randall, 357 U.S. 513 (1958), the Court described the criminal de. fendant's interest in his liberty as an "interest of transcending value." 357 U.S. at 525-26. Clearly, the interest in one's own liberty must be seen as of greater interest to the individual than such recognized fundamental interests as voting, see Harper v. Board of Elections, 383 U.S. 663 (1966), criminal appeals, see Griffin v. Illinois, 351 U.S. 12 (1956), and the right to travel. See Shapiro v. Thompson, 394 U.S. 618 (1969). In addition, because of the eighth amendment's prohibition against "cruel and unusual punishments," it has clearer constitutional origins than such unenumerated rights as the right to travel interstate.

345. In one of the first modern Supreme Court decisions to subject legislative classifications to a "strict" equal protection scrutiny, Justice Douglas seemed to suggest that the offender's fundamental interest in avoiding the unequal application of a harsh punishment (sterilization) justified use of the same "strict scrutiny" standard as is applied when a suspect classification is involved: "When the law lays an unequal hand on those who have committed intrinsically the same quality of offense and sterilizes one and not the other, it has made as invidious a discrimination as if it had selected a particular race or nationality for oppressive treatment." Skinner v. Oklahoma ex rel. Williamson, 316 U.S. 535, 541 (1942). At issue in Skinner was a punishment that was prescribed for the crime of grand larceny, but not for the equally blameworthy crime of embezzlement. By analogy, one can argue that the same "invidious" classification is made when two offenders convicted of the same crime are treated unequally because of factors unrelated to blameworthiness. Note, however, that the Skinner decision emphasizes the absence of a scientific justification for the disparity in treatment. 316 U.S. at 542. Thus, prediction tables, to the extent that they have been experimentally validated, present a somewhat different issue.

346. As noted earlier, prediction tables are more accurate and produce a lower total number of "false positives" than other techniques. In this sense, they represent a less intrusive infringement upon the individual's liberty. However, as discussed earlier at notes 196-201, if we define the offender's fundamental interest to comprehend the concept of "fairness between offenders" (i.e., freedom from unequal application of punishment in a manner unrelated to blameworthiness), then prediction tables no longer constitute less drastic means. 
sarily upon the offender's fundamental interests. While constitutional prohibitions on the punishment of status exist, courts have not yet connected this concept with that of "suspect classifications." Thus, if courts continue to apply a relaxed scrutiny test to cases not involving suspect classifications, it is unlikely that prediction tables will be found to violate the equal protection clause on the theory that they involve a punishment of status.

Yet, ultimately such a resolution is unsatisfactory. Since the judicial revolution of the New Deal, the minimal scrutiny test has been based on the assumption that courts should permit the legislature to experiment with respect to economic and social problems that the courts themselves are not competent to solve and that require democratic compromises. However, use of the minimal scrutiny standard is not justified in an area, such as the administration of justice, in which courts have both a special competence and a special role to play. ${ }^{347}$ Indeed, in the context of sentencing and parole, few legislative classifications (other than statutory sentence ranges) have actually been made; instead, the normal pattern is for the operative classifications to be made by administrative decision makers exercising unfettered discretion. Given the absence of authoritative legislative approval of such administrative practices as the Board of Parole's Salient Factor Score, judicial deference to any presumed intent of the legislature seems inappropriate. Thus, use of the less drastic means doctrine would remand to the legislature the critical choices that it has the initial option to make and remind it of the possible constitutional implications involved..$^{348}$

In short, a functionalist justification for strict scrutiny of dispositional classifications can be formulated-that is, that courts have a special duty to supervise classifications made within the criminal justice system-that is independent of the "suspect classification" and "fundamental interest" rationales. If this premise is accepted, then the less drastic means doctrine presents a useful device for avoiding a direct constitutional confrontation between the state's interest in accuracy and the individual's objection that his status,

347. See Gunther, supra note 335, at 30-31. As Professor Gunther points out, decisions such as James v. Strange, 407 U.S. 128 (1972), Jackson v. Indiana, 406 U.S. 715 (1972), and Humphrey v. Cady, 405 U.S. 504 (1972), illustrate that the current Court is relatively more willing to invalidate statutes on equal protection grounds in an area, such as criminal procedure, in which it has a special competence and responsibility.

348. See Gunther, supra note 335, at 44-48. Use of the less drastic means doctrine in effect remands an issue to the legislature and does not preclude further legislative action. This seems particularly appropriate where the indications are that the legislature has never consciously focused on the basic policy and constitutional issues involved. 
rather than his conduct, has become the chief determinant of the length of his incarceration.

\section{A Summary and Evaluation}

While the prognosis for procedural reform seems favorable, the likelihood of short term substantive reform of the sentencing process is at best speculative. Substantive appellate review of sentences is still at an embryonic stage. Similarly, the doctrine of proportionality cannot develop to its full potential as long as the philosophy of corrections remains in a transitional stage: Without agreement within the correctional system as to whether the purpose of confinement is rehabilitation or incapacitation, the proportionality of the punishment to the offense and the offender cannot be measured. Moreover, even if standards of proportionality can be agreed upon by courts, such standards will establish only maximum boundaries on the sentencing power. There remains then the secondary but substantial issue of fairness among offenders-the problem of ensuring equitable classifications and gradations within the outermost limits set by the concept of proportionality. In this area the courts have yet to take the first steps toward subjecting sentencing classifications to an equal protection analysis.

At the procedural level as well, important issues have simply not yet been addressed-for example, the problem of finding a mechanism by which diagnostic information and opinions can be reviewed, questioned, and challenged. Although Weston and its progeny have now clearly established a right to challenge and demand verification of material charges in the pre-sentence report, the movement toward procedural reform of the sentencing process in other important areas has been slow. One such area still awaiting judicial attention is the establishment of ground rules to preclude the use of inherently unreliable classes of information in the pre-sentence report.

Assuming then that courts will continue to individualize sentences on a case-by-case basis in the foreseeable future, and that the remedies foreshadowed in the emerging case law offer at best only a partial answer to the problems of individualization, what should be done? The answers that will next be considered involve a basic restructuring of the means by which dispositional information is presented to the decision maker.

\section{Restructuring the Sentencing Process}

Recent proposals for sentencing reform have tended to view sentencing disparities as primarily the result of either idiosyncratic prejudices or differences in judicial philosophies. Thus, in order to 
standardize the process by which sentencing information is assessed, reformers have generally advocated either adoption of sentencing councils or substantive appellate review of criminal sentences. ${ }^{349}$

The sentencing council is an advisory mechanism that requires the sentencing judge, before passing sentence, to discuss the offender's case with two other judges of the same district court who have reviewed the pre-sentence report. It is anticipated that this interchange of judicial views will lead the sentencing judge to moderate his own opinions and will result in the development of a general consensus. While proponents of the sentencing council believe that its use has led to greater leniency, researchers at the Federal Judicial Center have recently questioned the assumption that sentencing councils produce greater uniformity and have reached the preliminary conclusion that judges seem to persist in applying their own individual philosophies. ${ }^{350}$

Another attempt at standardization, analogous to the sentencing council, involves a variation on the numerical grading scale used in the prediction table. Judge Frankel has recommended that each sentencing judge grade the defendant before him on a numerical scale with respect to such factors as severity of the offense, emotional stability, and prior criminal involvement. His assumption is that judges share a relatively objective perception of the facts before them, but apply different judicial philosophies. ${ }^{351}$

349. One of the most forceful advocates of both reforms has been Judge Frankel of the Southern District of New York. For his views on the sentencing council, see M. Franker, supra note 1, at 70-71. At the time of his writing of Criminal Sentences, the sentencing council had been adopted in only three judicial districts in the United States. See Zavatt, Sentencing Procedure in the United States District Court for the Eastern District of New York, 41 F.R.D. 469 (1966). Those skeptical of the value of the sentencing counsel have suggested that its use may produce a diluted "committee" decision in which no judge has to face the ultimate responsibility of making a personal decision. Moreover, they have pointed to the generally poor performance of parole boards, which function along the same lines as sentencing councils. See W. GaYLIN, supra note 6 , at 223-24. Another problem has been raised by Judge Frankel: that adoption of the sentencing council could unfortunately become an "ersatz" substitute for true appellate review and thus would inhibit the necessary development of a substantive body of sentencing law. See Frankel, Who's To Review Federal Sentences?, N.Y.L.J., May 13, 1974, at I (criticizing an advisory committee proposal to amend rule 35 of the Federal Rules of Criminal Procedure to require a post-sentencing review by a sentencing council of any sentence in excess of two years). See also NATIONAL advisorx Comma. on Griminal Justice Standards and Goais, Report on Corrections C-120 to -122 (1973) (recommending the creation of sentencing appeals boards as an alternative to appellate review to achieve equality among offenders convicted of similar crimes).

350. A. PARTridge \& W. EldRIDge, supra note 12 , at 33 .

351. M. Frankel, supra note 1, at 113-14. Conversely, Professor Hogarth concluded in his monumental study that, once judges share relatively common perceptions of facts before them, they then tend to behave similarly in sentencing. The problem, Hogarth found, was that judges do not generally share such common perceptions of the operative facts: "The difficulty arises from the fact that different magistrates tend to perceive similar cases differently." J. HoGARTH, supra note 6, at 380 . The Second 
While these suggestions are useful, they share the common assumption that the fundamental problem in sentencing lies in differing judicial philosophies and attitudes among judges as to the proper penalty to be imposed. These critiques overlook the possibility that the information reaching the judge may be seriously distorted, presented in a manner that is susceptible to selective interpretation, or affected by the institutionalized biases present in current recordkeeping procedures. As a result, similarly situated offenders may be made to appear dissimilar.

Any program for sentencing reform must deal with two basic assumptions of the current system: the concept of the probation officer as a neutral investigator, able to gather and assess the available information about the offender with detached impartiality, and the belief that an all-inclusive approach to data collection best serves the decision maker by providing him with an in-depth understanding of the offender. If (as we have seen) these premises are no longer viable, then one is left with a procedural structure from which the theoretical keystones have been removed. In their place, two basic proposals will be made: first, that the system reduce its dependence on the probation officer as the conduit of information and evaluation by using defense-conducted pre-sentencing studies, and, second, that unnecessary data collection be circumscribed in candid recognition of the fact that the goal of total understanding of an individual is dangerous and illusory.

\section{A. Increasing the Conduits of Information: The Case for a Parallel Pre-Sentence Study by Defense Counsel}

The contemporary pre-sentence investigation is essentially an "inquisitorial" rather than an "adversarial" process. Social scientists have used the foregoing terms to distinguish legal procedures in which a single-skilled factfinder is relied upon to make the relevant determinations from those in which factual issues are resolved after competing presentations by counsel. .52 $^{2}$ The relevance of this distinction for sentencing purposes becomes obvious when experimental findings comparing the relative efficacy of the two techniques are examined. Recently, a team of psychologists and lawyers at the Uni-

Circuit Sentencing Study prepared by the Federal Judicial Center also casts doubts on the idea that disparities result because some judges are "tough" and some "soft" on sentencing, concluding that most judges tend to behave in a highly individualistic manner, sometimes assigning severe sentences and sometimes lenient ones. A. PARTRIDGE \& W. ELDRIDGE, supra note 12, at 37. According to this view, even if each judge is highly consistent in terms of his own pattern, the aggregate results will remain erratic.

352. Thibaut, Walker \& Lind, Adversary Presentation and Bias in Legal Decisionmaking, 86 HARV. L. REv. 386, 388 (1972). 
versity of North Carolina published the findings of experiments designed to test the impact of adversarial presentation under controlled laboratory conditions. ${ }^{353}$ As a hypothesis for their research, they adopted the observation of the legal philosopher, Lon Fuller, that only an adversarial presentation can effectively counteract the "natural human tendency to judge too swiftly in terms of the familiar that which is not yet fully known." 354 Fuller's thesis was that in most legal proceedings in which evidence is heard, a point is reached at which the facts begin to suggest a familiar legal label; at this point, without the safeguard of an adversarial presentation, a danger exists that hasty stereotyping will occur with the result that "what starts as a preliminary diagnosis designed to direct the inquiry tends, quickly and imperceptibly, to become a fixed conclusion . . . ."355 The findings of the North Garolina study confirmed Fuller's thesis, ${ }^{356}$ and added an additional finding: decision makers tend to avoid extreme judgments when subjected to an adversary presentation..$^{357}$

Laboratory experiments are, of course, open to the criticism that they do not adequately recreate the reality of the courtroom. It is noteworthy that in the one sentencing proceeding in which attorneys have historically been permitted to participate, the juvenile court dispositional hearing, a team of social scientists has noted that the presence or absence of counsel has a significant effect on the severity of the sentence imposed. ${ }^{358}$ What puzzled these scientists was that even where the attorney did not actively participate at sentencing, the client still received a less severe sentence than where an attorney was not present. These two sets of experiments suggest that the presence of an attorney, even in a passive role, may inhibit the tendency that exists in an "inquisitorial' proceeding to pigeonhole the subject too quickly.

The findings of these studies point toward a highly unorthodox conclusion: some role for adversarial tactics at the dispositional stage may be essential. This modification of the sentencing procedure would not only reduce the probation officer's monopoly over dispo-

353. Thibaut, Walker \& Lind, supra note 352.

354. Fuller, The Adversary System, in TALks on AMERICAN LAw 34, 44 (H. Berman ed. 1971), quoted in Thibaut, Walker \& Lind, supra note 352 , at 390 .

355. Fuller, supra note 354, at 43. The result, Fuller adds, is that "all that confirms the diagnosis makes a strong imprint on the mind while all that runs counter to it is received with diverted attention." $I d$. at 44 . In this respect, Fuller's thesis bears a strong resemblance to the theory of cognitive dissonance and Professor Hogarth's findings. See notes 174-75 supra and accompanying text.

356. Thibaut, Walker \& Lind, supra note 352 , at 401 .

357. See id. at 399 .

358. Ferster \& Courtless, Pre-Dispositional Data, Role of Counsel and Decisions in a Juvenile Court, 7 L. \& Soc. REv., Winter 1972, at 195, $206-07$. 
sitional information, but would also begin to rationalize the basically subjective attempt to gauge human character by ensuring that the dispositional authority was made aware of alternative evaluations and of the latitude of possible interpretations. In particular, defenseinitiated pre-sentence reports may offer a solution to the tendency toward overprediction that appears to be inherent in clinical and diagnostic information. Except in extreme cases, it is unlikely that the alternative of courtroom cross-examination of the psychiatrist would prove feasible. ${ }^{359}$ Instead, reciprocal disclosure of psychiatric reports and evaluations between the probation office and defense counsel would permit commentary and criticism by each side's experts without ensnarling the psychiatrists in a full-scale hearing. ${ }^{800}$ In addition, there is reason to believe that this type of adversarial procedure would place strong role pressure on the clinical expert to avoid extreme characterizations of the offender. ${ }^{361}$

As prediction tables and similar rating devices come into greater use at the sentencing stage, the case for allocating a greater role to defense counsel is strengthened. Because prediction tables by definition focus on a few pre-selected variables and ignore other data, it becomes more feasible to permit defense counsel to contest the accuracy of the critical facts that under such rating systems would have a demonstrable impact on the risk level assigned the offender. ${ }^{802}$ At the same time, because these tables are incapable of giving effect to information for which no pre-determined value has been assigned, they tend to create irrebutable presumptions, unless defense counsel

359. A number of arguments have been advanced as to why the psychiatrist should not be cross-examined, many of which overlap with the reasons underlying the exception in rule 32(c) of the Federal Rules of Criminal Procedure permitting the sentencing judge not to disclose diagnostic opinions in certain circumstances. In addition to the standard arguments that the psychiatrist would be inhibited in his future communications to the court and that the doctor-patient relationship would be impaired, Judge Dembitz of the New York Family Court has argued persuasively that such a step would consume the very scarce supply of forensic psychiatrists available to the courts. See In re Blaine, 54 Misc. $2 \mathrm{~d}$ 248, 256-57, 282 N.Y.S.2d 359, 367 (Fam. Ct. 1967).

360. Also, asking the court psychiatrist to reply in writing to the questions or criticisms of another clinician or to consult and produce a joint evaluation seems less likely to provoke a defensive reaction than subjecting him to cross-examination.

361. Thibaut, Walker, and Lind discuss "attribution" theory as a possible explanation of their results. The theory suggests that the legal decision maker is under strong "role pressure" to avoid any manifestation of bias, and will therefore be reluctant to react negatively to information or views which oppose his bias. The authors suggest that the adversarial process intensifies this pressure, with the result that the decision maker will be more likely to balance his judgment.

362. Put simply, as the scope of the information that could have a material impact on the sentence assigned is reduced, it represents less of a procedural burden to permit greater use of adversarial tactics (such as the presentation of witnesses and crossexamination) in order to rebut challenged facts. Conceivably, the use of such tactics could be restricted to situations in which defense counsel could show that rebuttal 
is given an opportunity effectively to present any redeeming information that has been ignored by such tables. ${ }^{363}$

In one sense, the idea of a defense conducted pre-sentence study represents only an extension of the defendant's common-law right of allocution - the ancient, but limited, right to address to the sentencing judge any reasons why the sentence should be mitigated. The President's Commission has recommended that defense counsel have access to auxiliary services resembling those available to a modern and well-equipped probation office. ${ }^{364}$ Nor is the idea of a defense conducted pre-sentence study unprecedented: In the English sentencing system, the defense counsel typically presents extensive information to the court, occasionally calling witnesses and developing arguments at considerable length. ${ }^{385}$ The success of this idea, however, hinges upon the answers to two basic questions. First, will sentencing judges be willing and able to rely upon the accuracy and candor of defense-conducted studies? Second, would the defense's clinical experts be able to protect the integrity of their findings from overzealous attorneys?

Preliminary experience with defense-conducted studies suggests that both questions can be answered affirmatively. The Washington, D.C. Legal Aid Agency conducted experimental studies on these questions for several years, using a staff that included a psychiatrist, social workers, and investigative paraprofessionals. ${ }^{368}$ In overview, three points seem significant about the Washington experiment: first, dealing with randomly assigned defendants and approaching

of the challenged information would result in a different classification under the rating system being employed.

It is, of course, essential to such a procedure that the nature and mechanics of any prediction table or other rating system be fully disclosed to defense counsel. Revised rule 32(c) of the Federal Rules of Criminal Procedure can be narrowly read not to require disclosure of such information, since it is not literally a part of the presentence report. The purposes underlying the revisions to rule 32 would, however, be substantially frustrated if such a restrictive interpretation were followed.

363. Prediction tables inevitably are limited to the factors incorporated in the validation tests upon which they are based. To the extent that they are assumed by the dispositional authority to represent a summary evaluation of all the relevant information about the offender, they create a misleading impression, which defense counsel should be permitted to correct.

364. Challenge of Crume, supra note 65, at 151.

365. Meador, supra note 14, at 108-09. Dean Meader noted that defense counsel's presentation is basically adversary in form. Id. at 108. Indeed, under English sentencing procedures, the role played by defense counsel far exceeds that of the prosecution. Symposium, A Criminal Case in England: From Arrest Through Appeal, 10 AM. CRIM. L. REv. 263, 315 (1971). See Meador, supra, at 107-09.

366. Dash, Medalie \& Rhoden, Demonstrating Rehabilitative Planning as a Defense Strategy, 54 CORNELr L. Rev. 408 (1969). See also Medalie, The Offender Rehabilitation Project: $A$ New Role for Defense Counsel at Pretrial and Sentencing, 56 GEo. L.J. 2 (1967). 
their cases as a social worker would a client, the defense team apparently was able to acquire substantially more information than were the probation officers conducting the official pre-sentence study (who alone had access to the official records); ${ }^{387}$ second, the defense attorney's participation in the process was limited by strict ground rules, and no editing of the defense report was permitted; ${ }^{308}$ finally, a high level of judicial acceptance of defense recommendations was obtained, in part because probation was not automatically recommended. ${ }^{369}$

Equipping public defender agencies with the resources to prepare separate pre-sentence reports will obviously be costly. In return, it introduces into the dispositional process the important element of adversarial persuasion without adding the trial-type standards that courts since Williams $v$. New York have sought to avoid.

\section{B. Circumscribing Data Collection: The Case for Less Knowledge}

In summary, this article has argued that the pursuit of complete understanding of the offender has led to three adverse consequences. The first of these consequences is a Gresham's law effect: "Bad" information drives out the "good" because the pre-sentence inquiry degenerates into a search for previously recorded adverse labels. Faced with a constant need to classify a large number of individuals quickly, the decision maker often seizes upon any recorded information that will provide him with a basis for differentiation, regardless of how remote in time or tenuous in its significance it may be.

The second adverse consequence is the problem of sensory overload-more information is assembled than can be meaningfully put to use. A consequence of this excessive accumulation of data is the tendency for the decision maker to make selective use of individual items of information so as to confirm his initial attitude toward the offender. Superfluous detail thus blinds the sentencing judge to the basic similarities between offenders and thereby multiplies the possibilities for sentencing disparities.

367. Dash, Medalie \& Rhoden, supra note 366 , at 424 . In part, this ability was based on longer association of the defense team with the defendant (beginning shortly after arrest) and the defendant's resulting greater confidence in the team.

368. Id. at 425. The attorney was permitted to use or not to use the report on an all-or-nothing basis, but not to quote selectively from it. Id. Failure to use this report in such a procedure would probably have signaled to the sentencing judge that the report's findings were adverse.

369. Probation was recommended in slightly more than half the cases handled, with a 75 per cent rate of judicial acceptance. $I d$. at 426. In addition, the defense team undertook a plan of total rehabilitation strategy for the offender, often finding him employment or locating educational programs. Id. at 427. 
Finally, the pursuit of complete understanding of the offender results in the problem of unevenness. While ideally it might be desirable to understand the offender in complete idiosyncratic detail, the practical consequence of this attempt in a world inhabited by decision makers who must act on the basis of comparative appearances is the differentiaton of offenders on the basis of their vulnerability to institutional record-keeping. Because of the great disparities in the probability that prior misconduct will result in an accessible record, the attempt to find all records relating to the offender's past life ensures that those individuals who are "record-prone" will be prejudiced.

In the last analysis, these and other deficiencies can be summarized by saying that in the attempt to gather information about most individuals there exists a point of diminishing returns, which, once passed, leads not to greater clarity, but only to confusion and false comparisons. The assiduous gathering of speculative hunches, stale data, and other random fragments of information in the name of total knowledge, benefits few and may injure many.

Few images of the law in action are more chilling than the relentless, unending pursuit of Jean Valjean in Victor Hugo's Les Misérables for the petty crime of stealing a loaf of bread. This image frightens us because it shows the law to be unforgiving, implacable, and, above all, pointlessly obsessed with preventing the individual from escaping his past misdeeds, however trivial. ${ }^{370}$ This same obsessive concern is present in the current sentencing ideology, which insists that the offender's past life be fully portrayed from the time of his first juvenile encounter with law enforcement authorities. Not only is this effort disproportionate to the results that can be achieved, but this initial error is compounded by the further insistence on extrapolating an impressionistic portrait of the offender from such isolated facts.

An appropriate starting point for the reform of present systems of data collection would be to refocus dispositional criteria on those classes of data that are available on a relatively equal basis for all offenders in order that each pre-sentence inquiry might employ a uniform threshold level of attention. Rules should be formulated to exclude from the pre-sentence report unreliable data, such as

370. Historically, American society has placed a high value on the idea that every individual should be entitled to a "second start." As a number of American social critics and historians, beginning with Frederick Jackson Turner, have pointed out, by escaping to the frontier or the city, the individual could discard the limitations of the past and start anew. For an analysis of the impact of modern record-keeping on this theme of the second chance see C. Lister, The Confidentiality of Pupil's School Records 69, (1969) (unpublished; available on request from the Riusell Sage Foundation, 230 Park Ave., New York, New York). 
arrest records, most pupil records, and pre-delinquency predictions, that may be distorted by the subject's exposure to record-keeping. Similarly, a standard must be established by which the inclusion of stale data is proscribed. ${ }^{371}$ Such rules need not bar all information that falls short of a criminal conviction, ${ }^{372}$ but they must protect the principle that a mere encounter with the law, such as an arrest, is a neutral event without legal significance. ${ }^{373}$

More difficult questions arise when we turn our attention from law-enforcement and similar accusatory records to the broader problem of the attempt made during the pre-sentence inquiry to understand the "whole person" of the offender. At a minimum, most recent critics would agree that the current attempt to portray each offender at full length fails to provide a sufficient degree of standardization. Some critics would go farther and argue that it is beyond the competence of the criminal justice system to consider any factors other than the offender's criminal act. ${ }^{374}$ In their favor, it must be observed that the judging of innate character is a task for which novelists and historians, not lawyers, have the appropriate training, temperament, and control over their subjects, as well as the ultimate

371. Cf. 15 U.S.C. $\$ 1681$ (c) (Supp. I 1971) (barring the reporting of credit information older than seven years). See also sources cited in note 239 supra. Although certain items of information (such as a prior conviction) might be useful regardless of age, it seems clear, for instance, that at some point an ancient arrest record no longer possesses probative value.

372. Thus, information in the prosecution file of other serious crimes that werc not prosecuted because of the instant conviction could be included if the prosecution is prepared to introduce corroborative testimony. The important point is that unsupported allegations of prior criminal activity should not be considered, both because of the axiomatic principle of presumed innocence and because of the discriminatory impact of the use of such data.

373. Opponents of such a reform can argue that the judge, unlike the jury, has traditionally been permitted to consider at a voir dire incompetent or inadmissible evidence. Yet a major difference exists between the situation of the defendant at trial and at sentencing: at trial, he is protected by the requirement of proof beyond a reasonable doubt; at sentencing, he may be subjected to years of additional imprisonment based on nothing more than speculation.

374. See, e.g., Struggle For Justice, supra note 2, at 144-45. Although the viewpoint in Struggle for Justice, that discretion should be completely eliminated, has gained few adherents, an increasing number of judges and academics have begun to support the idea of requiring mandatory, short, fixed sentences for most crimes. A variety of justifications for such a policy have to date been advanced: the need for increased deterrence, the desirable effect of a "sudden short sharp shock" (namely, prison) upon the offender, the need to reduce both sentencing disparities and the "revolving door" aspects of the criminal justice system, and the advantages of ending prisoner uncertainty as to the length of their sentences. For representative discussions of the policy of mandatory fixed prison terms, see L. ORLAND \& H. TYLER, JR., Justice IN SENTENCING 75 (1974) (comments of Judge Constance Baker Motley and Dean Abraham Goldstein); J. Wison, Thinking About Crme $162-82$ (1975); Cover Story: The Crime Wave, TMM, June 30, 1975, at 10, 21-24 (cataloging recent experiments with mandatory, short, fixed sentences). At a minimum, this trend shows that the concept of individualization is at least on the defensive and subject to criticism. Salutary as such a transition seems, it must, however, be noted before the pendulum 
responsibility if they fail. Yet, the total elimination of discretion from sentencing would also extinguish discretion's corollary, compassion. Moreover, even if discretion were denied judges, it would still remain in the hands of the prosecution and police, who would continue to decide which offenders were to be charged and for what offense. While this article will not attempt to settle the debate between the critics opposed to discretion and those who maintain that objective criteria do exist to differentiate among offenders, ${ }^{375}$ one suggestion might be made: The degree to which the pre-sentence inquiry should be curtailed should be a function of the degree to which defense counsel is permitted to assume an advocate's role in the presentation and rebuttal of dispositional information. To the extent that defense counsel is denied this role, the case for curtailing the pre-sentence inquiry becomes stronger. ${ }^{376}$

Over the past few years, the idea of appellate review of criminal sentences has received considerable support, ${ }^{377}$ but relatively little clarification. In general, its proponents have called for the development of a substantive body of law to determine when offenders should be sent to prison and for what duration. ${ }^{378}$ Although a consensus has emerged that the sentencing judge should operate within the traditional judicial structure of precedent and established procedures, few have offered any specific rules by which to guide him. Nor does it seem realistic to expect appellate courts to postulate a laundry list of agreed-upon factors that, when properly weighed and balanced, will produce the correct sentence. Accordingly, it is the suggestion of this article that the natural starting point for the development of a substantive body of sentencing law is the creation

swings back to the "tariff" sentencing system of earlier times (which prescribed fixed sentences for each crime) that, to the extent our interest is in achieving equality in sentencing, a sentencing structure that treats dissimilarly situated persons similarly is as potentially open to criticism on grounds of inequality as one that treats similarly situated persons dissimilarly.

375. Given the assumption that discretion cannot safely be omitted from the sentencing process, one is forced back upon what are admittedly loose distinctions in describing how the pre-sentence inquiry might be appropriately curtailed: (l) subjective interpretations of character and motivation would be de-emphasized in favor of a focus generally restricted to overt behavior; (2) the concept of a novelistic presentation of information would be largely abandoned to be replaced by graded scales and comparative rankings; and (3) predictions of future misconduct or delinquency would be purged from the presentence report unless (a) expressly made in order to describe the current status of the offender, and (b) presented in a manner that sufficiently sets forth the prediction's premises so as to be "attackable."

376. In short, it is unduly simple to suggest that there is only one ideal sentencing structure; the problems of misinformation and discrimination are susceptible to a variety of rational responses. But some degree of curtailment and some additional role for defense counsel seem necessary, since neither alone offers a satisfactory solution.

377. See note 4 supra.

378. See, e.g., ABA Appellate Review Standards, supra note 4, at 27-30. 
of a framework of relevance. By this it is meant that the first task in the institutionalization of appellate review of criminal sentences should be the development of standards to govern the kinds of data and information that may be considered at sentencing. Traditionally, lawyers operate by narrowing the issues and facts involved in a dispute to those that can be agreed upon as having legal relevance. Thus, if sentencing is to follow a legal mode of decision-making, the first step seems inevitably to involve a narrowing of the virtually infinite spectrum of information that is currently deemed relevant at sentencing. From such a framework of relevance would come two advantages: first, issues would be more sharply defined for the dispositional authority to focus upon and resolve; and, second, such procedural formalization would gradually produce greater uniformity and consistency in the kinds of justifications that might be used to support variations in imprisonment.

Curtailment of the pre-sentence inquiry undeniably entails risks: Important facts may on occasion elude discovery; the risk of identifying an unacceptable level of false positives may at times inhibit the detection of truly dangerous offenders. But, these same risks exist at the trial stage, where our system of justice has prided itself on allocating the balance of advantage to the defendant. If we wish to maximize the perceived equity of the sentencing process, this balance of advantage should be extended to the sentencing stage (and to the vast majority of defendants who forgo trial) by the creation of a functional equivalent to the presumption of innocence that prevails at trial. This presumption - call it, perhaps, a "presumption of normality"would assume, in the absence of unambiguous information to the contrary, that the offender was at least no worse than others convicted of the same crime. In effect, society would abandon the hope of complete knowledge of the offender in favor of a deliberate constructive ignorance of prior minor transgressions and speculative possibilities. In return, this presumption of normality would ensure that the goal of individualization would henceforth be pursued only on the basis of real differences among offenders.

Inevitably, a tension exists between two conflicting goals of dispositional decision-making-individualization and equality. This article suggests that the balance be tipped toward equality by curtailing the permissible justifications for disparate treatment. Although essentially conservative, this position seems at least temporarily mandated: In the last analysis, unless the concept of individualization is revitalized along lines similar to those suggested above, pressures seem likely to build that will lead to the abandonment of the concept rather than to its modification. 